\title{
Spatial vegetation ecology: \\ Understanding the ecosystem processes that influence plant diversity patterns at different spatial scales
}

Habilitationsschrift

zur Erlangung der Lehrbefugnis

für das wissenschaftliche Fachgebiet

Botanik (Vegetationsökologie)

vorgelegt der

Fakultät für Biologie und Psychologie der

Georg-August-Universität Göttingen

von

Dr. rer. nat. Heike Culmsee

aus Hannover

Osnabrück und Göttingen, 2014

Die Lehrbefähigung im wissenschaftlichen Fachgebiet Botanik (venia legendi) wurde am 17.02.2015 verliehen 


\section{Contents}

Contents . .1

Organisation of the thesis .3

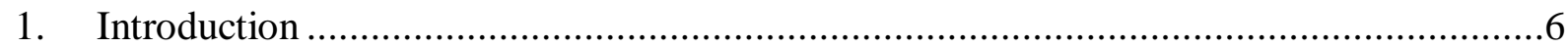

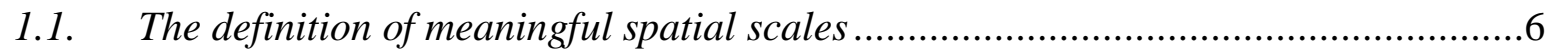

1.2. Biological diversity and the description of plant diversity patterns ........................6

1.3. The plant community ....................................................................................

1.4. The conceptual framework for partitioning diversity at different spatial scales .......7

1.5. Taxonomic, functional and phylogenetic diversity of plant communities ..................8

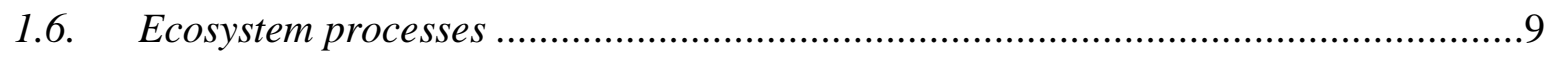

1.7. Examining the relationship of plant diversity and ecosystem processes at different

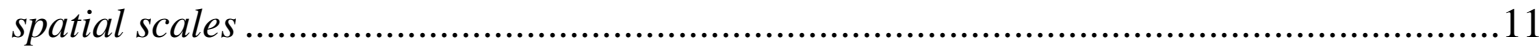

2. Climatic gradients and biogeographical processes across Malesian mountain rain forests.

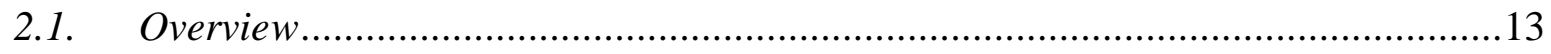

2.2. The study area Sulawesi and the Malesian context ............................................14

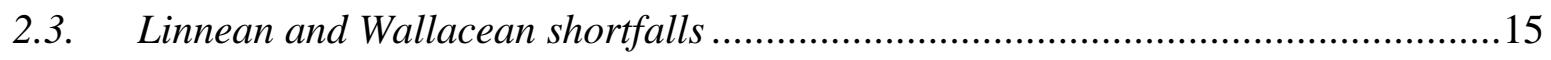

2.4. Tree inventories as a basis for the analysis of regional patterns in tree diversity

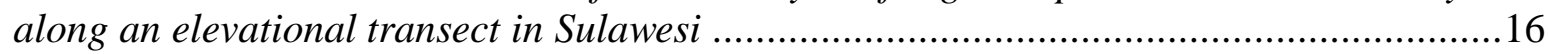

2.5. Studying diversity patterns of coexisting groups: The example of bryophyte communities occurring on tree trunks in relation to tree species traits ...............................20

2.6. Analysing biogeographical processes across Malesian mountain forests................20

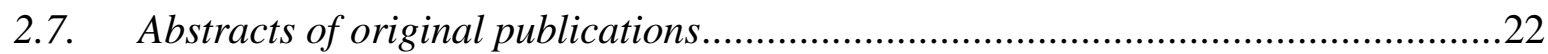

3. Carbon pools of tropical montane forests from the local to global scales ......................26

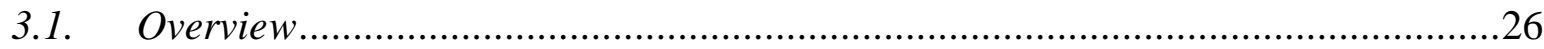

3.2. Estimating the aboveground biomass of tropical forests ....................................27

3.3. The role of tropical montane forests as global carbon stores ................................28

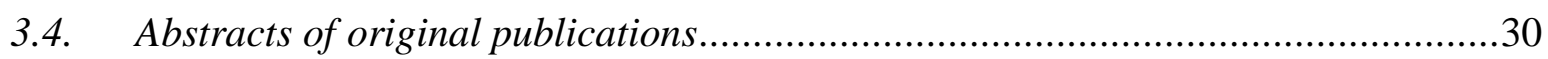

4. Regional plant diversity patterns in temperate forests of northwest Germany ...............32

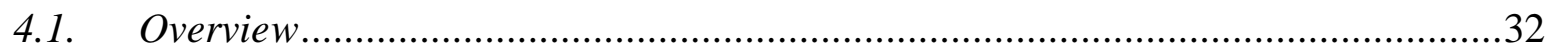

4.2. Forest conditions and nature conservation value of forests in northwest Germany 33

4.3. Advancing methodological approaches of identifying indicator species to facilitate

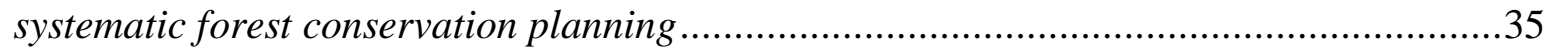

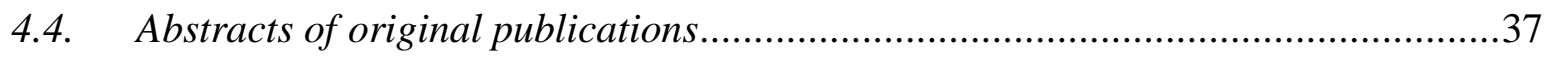

5. The implications of land use change for the diversity of ecologically valuable grasslands and arable plant communities of annual crop fields in north and central Germany.................39

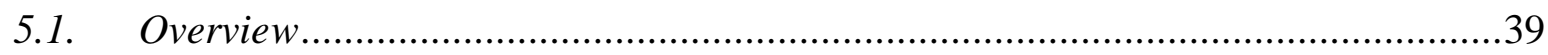


5.2. A brief historical outline of land use change in Central European rural landscapes . 41

5.3. Analysing temporal changes in plant diversity patterns at different spatial scales .43

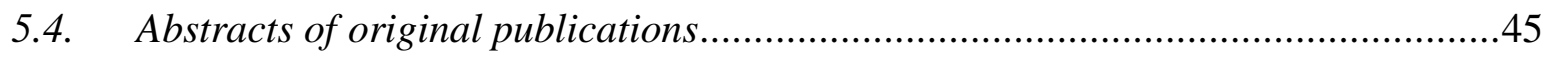

6. Zusammenfassung der Veröffentlichungen .........................................................48

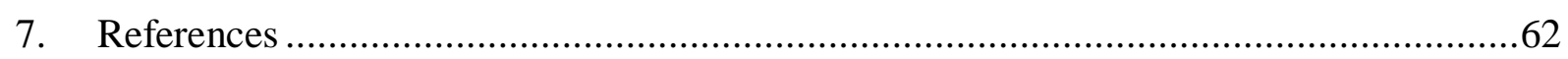




\section{Organisation of the thesis}

The present thesis is based on a set of 16 peer-reviewed publications originating from ecological research work aimed at understanding how ecosystem processes may influence plant diversity patterns at different spatial scales. The first chapter of the text provides an overall introduction to the topic. Each of the following four chapters sets the framework for the relevant publications by linking their contents and summarising methodological approaches.

In each of the Chapters $2-5$, the focus is exemplarily set on specific spatial scales in order to shed light on different aspects of plant diversity and on the scale-related types of underlying ecological and/or biogeographical processes. Research was carried out in diverse types of ecosystems. Chapters 2 and 3 focus on tropical mountain rain forests of Sulawesi (Indonesia), and continental and cross-continental comparisons are made with other tropical rain forest ecosystems. Chapter 4 focuses on temperate forests of northwest Germany and Chapter 5 on agricultural ecosystems (grasslands and arable fields) of north and central Germany.

The publications themselves, which form the main part of the thesis, are listed below and can be found in their original format in the Appendix B. The German translation of the abstracts is given in Chapter 6.

\section{List of publications relevant for the thesis}

(Notes in brackets indicate which part of the work was done by me)

Chapter 2 - Climatic gradients and biogeographical processes across Malesian mountain rain forests

Berg, C.C., Culmsee, H., 2011. Ficus schwarzii redefined and two new species of Ficus (Moraceae) from Sulawesi (Indonesia) described. Blumea, 56: 265-269.

(Field collections, illustrations of species, part of writing and editing the paper)

Brambach, F., Nooteboom, H.P., Culmsee, H., 2013. Magnolia sulawesiana described, and a key to the species of Magnolia (Magnoliaceae) occurring in Sulawesi. Blumea, 58: 271276.

(Part of field collections and identification of specimens, illustrations, part of writing and editing the paper)

Culmsee, H., 2008. Dysoxylum quadrangulatum, and notes on Meliaceae in Sulawesi. Blumea, 53: 602-606.

(Field collection, identification as a new species, illustration, writing and editing the paper)

Culmsee, H., Leuschner, C., 2013. Consistent patterns of elevational change in tree taxonomic and phylogenetic diversity across Malesian mountain forests. Journal of Biogeography, 40: 1997-2010.

(Idea, tree inventories and identification of tree specimens of the Sulawesi plots, methodological approach and data analysis, larger part of writing and editing the paper) 
Culmsee, H., Pitopang, R., 2009. Tree diversity in sub-montane and lower montane primary rain forests in Central Sulawesi. Blumea, 54: 119-123.

(Idea, field work in cooperation with Indonesian partner, identification of tree species, all part of data analysis, writing and editing the paper)

Culmsee, H., Pitopang, R., Mangopo, H., Sabir, S., 2011. Tree diversity and phytogeographical patterns of tropical high mountain rain forests in Central Sulawesi, Indonesia. Biodiversity and Conservation, 20: 1103-1123.

(Idea, field work in cooperation with Indonesian partners, identification of tree species, all part of data analysis, writing and editing the paper)

Gradstein, S., Culmsee, H., 2010. Bryophyte diversity on tree trunks in montane forests of Central Sulawesi, Indonesia. Tropical Bryology, 31: 95-105.

(Tree inventories and identification of tree species, data analysis, part of editing the paper)

Chapter 3 - Carbon pools and biomass of tropical forests from local to global scales

Culmsee, H., Leuschner, C., Moser, G., Pitopang, R., 2010. Forest aboveground biomass along an elevational transect in Sulawesi, Indonesia, and the role of Fagaceae in tropical montane rain forests. Journal of Biogeography, 37: 960-974.

(Idea, field work in cooperation with Indonesian partner, identification of tree species and data analysis, main part of writing and editing the paper)

Hertel, D., Moser, G., Culmsee, H., Erasmi, S., Horna, V., Schuldt, B., Leuschner, C., 2009. Below- and above-ground biomass and net primary production in a paleotropical natural forest (Sulawesi, Indonesia) as compared to neotropical forests. Forest Ecology and Management, 258: 1904-1912.

(Tree inventory part of field work, tree species identification, AGB data analysis, part of editing the paper)

Leuschner, C., Moser, G., Hertel, D., Erasmi, S., Leitner, D., Culmsee, H., Schuldt, B., Schwendenmann, L., 2013. Conversion of tropical moist forest into cacao agroforest: Consequences for carbon pools and annual C sequestration. Agroforestry Systems, 87: 1173-1187.

(Tree inventory part of field work and AGB data analysis for natural forest plots)

Chapter 4 - Regional plant diversity patterns in temperate forests of northwest Germany

Culmsee, H., Schmidt, M., Schmiedel, I., Schacherer, A., Meyer, P., Leuschner, C., 2014. Predicting the distribution of forest habitat types using indicator species to facilitate systematic conservation planning. Ecological Indicators, 37: 131-144.

(Idea, data analysis, main part of writing and editing the paper)

Schmidt, M., Mölder, A., Schönfelder, E., Engel, F., Schmiedel, I., Culmsee, H., 2014. Determining ancient woodland indicator plants for practical use: A new approach developed in northwest Germany. Forest Ecology and Management, 330: 228-239. (Part of writing and editing the paper) 
Chapter 5 - The implications of land use change for the diversity of ecologically valuable grasslands and arable plant communities of annual crop fields in north and central Germany

Krause, B., Culmsee, H., 2013. The significance of habitat continuity and current management on the compositional and functional diversity of grasslands in the uplands of Lower Saxony, Germany. Flora, 208: 299-311.

(Idea, main parts of data analysis, writing and editing the paper)

Krause, B., Culmsee, H., Wesche, K., Bergmeier, E., Leuschner, C., 2011. Habitat loss of floodplain meadows in north Germany since the 1950s. Biodiversity and Conservation, 20: 2347-2364.

(Idea on the analysis approach, large part of writing and editing the paper)

Seifert, C., Leuschner, C., Meyer, S., Culmsee, H., 2014. Inter-relationships between crop type, management intensity and light transmissivity in annual crop systems and their effect on farmland plant diversity. Agriculture, Ecosystems and Environment, 195: 173182.

(Large part of writing and editing the paper)

Wesche, K., Krause, B., Culmsee, H., Leuschner, C., 2012. Fifty years of change in Central European grassland vegetation: large losses in species richness and animal-pollinated plants. Biological Conservation, 150: 76-85.

(Part of idea on sampling design and of editing the paper) 


\section{Introduction}

\subsection{The definition of meaningful spatial scales}

The definition of meaningful spatial scales to explain processes that influence plant diversity is crucial for the development of general predictions on ecosystem trends (Levin, 1992; Whittaker et al., 2001; Chave, 2013). However, it raises a number of difficulties in that the scale of sampling must relate to the phenomena to be measured and, to date, this is poorly understood (Webb et al., 2008). There is no particular natural scale at which ecological phenomena should be studied (Levin, 1992). Different ecosystems have different levels of organisational complexity, and processes occur over varying time periods and at varying ranges of spatial scale (Wiens, 1989). It is therefore important to acknowledge that patterns may be created at scales that differ from that at which the corresponding processes act (Chave, 2013). Sampling is stochastic if the scale of observation is too small, and observed variability is dependent on the scale being described. As such, it is crucial to distinguish between the grain of the data (i.e. the size of the individual units of observation, such as 1-ha plots or latitude-longitude grid cells, which defines the lower limit of resolution in a study), and the extent of a study system (often used synonymously with scale, i.e. the overall area over which observations are made, which defines the upper limit of resolution in a study) (Wiens, 1989; Whittaker et al., 2005).

In addition, scales of ecological and evolutionary processes can merge continuously (Webb et al., 2002, 2008; Ackerly, 2003; Cavender-Bares et al., 2009). Plant communities assemble from a (regional) pool of species that is influenced by biogeographical history (Carstensen et al., 2013), but the actual composition of the (local) sample is influenced by contemporary ecological interactions and environmental constraints (Ackerly, 2003; Webb et al., 2008). Natural breaks that correspond to different environmental and biogeographical transitions, so-called 'particular scales of interest', can however be selected (Levin, 1992). Webb et al. (2008) defined six potential levels of the extent of study systems that are hereafter referred to as explicit spatial scales: (1) Global (the total extent of an ecosystem); (2) continental (1000$10,000 \mathrm{~km}$, within which climatic and biogeographical gradients may occur); (3) regional (10-

$1000 \mathrm{~km}$, fairly homogeneous in climate and biogeographical history); (4) local (1-10 km, genetic exchange is usually possible in one or a few generations); (5) habitat (10-1000 m, a lithologically or topographically defined patch); and (6) neighbourhood (0-10 m, the scale of direct inter-plant interactions).

\subsection{Biological diversity and the description of plant diversity patterns}

In accordance with the CBD (1992), 'biological diversity' refers to the degree of variability among living organisms; this includes diversity both within and between species, as well as that of ecosystems. In this study, I focus on diversity among vascular plants of terrestrial ecosystems in the context of the ecological complexes of which they form part. The first step in the examination of plant diversity is to establish suitable measures that can be used to describe patterns or trends in diversity, so that criteria can be established for relating such 
patterns to the underlying processes. 'Pattern' implies variation, as in the definition of biological diversity, and, in addition, a degree of repetition. The quantification of variation requires the identification of scales, and repetition implies that prediction is possible (MacArthur, 1984; Levin, 1992; Chave, 2013).

\subsection{The plant community}

The basic unit referred to in vegetation ecology is the plant community, which is defined as a set of different species co-occurring at a specified location in space and time (e.g. McGill et al., 2006; Ricklefs, 2008). The species composition of a plant community is classically sampled at the habitat scale, i.e. each sample covers a defined area of a vegetation stand on a more or less lithologically and topographically homogeneous patch (Braun-Blanquet, 1964; Chytrý \& Otýpková, 2003). Following the Braun-Blanquet approach, a sample is selected on the basis of uniformity and discreteness of the vegetation stand, and plant communities are considered integrated units that can be studied as such and classified according to their composition and community structure (determination of diagnostic species, see overview by Chytrý et al., 2002a). It is therefore necessary to distinguish between concrete stands (observations of species assemblages found in local sites, i.e. samples of a plant community) and the abstract concept of the plant community (van der Maarel, 2005). A worked example of Central European spruce forests by Chytrý et al. (2002b) reveals that the delimitation of diagnostic species is highly dependent on the ranges of species available for classification. Hence, the composition of local plant assemblages is dependent on the spatial extent of their component populations. Populations have a geographic structure defined by dispersal limitations, but they exhibit integration over spatial scales that greatly exceed the usual extent of local communities (Ricklefs, 2008).

\subsection{The conceptual framework for partitioning diversity at different spatial scales}

Whittaker $(1960,1972)$ offered a conceptual framework for partitioning species diversity at different spatial scales of organisational complexity. He introduced hierarchical terms: alpha diversity refers to within-habitat diversity, beta diversity to among-habitat differentiation (the extent or rate of change in community composition in relation to a more or less complex gradient of the environment), and gamma diversity to the total species diversity at the regional or landscape scale. The different components of alpha, beta and gamma diversity are functionally related to each other (Jost, 2007; Tuomisto, 2010a).

There has been a plethora of discussion and research on statistical approaches aimed at measuring species diversity (see overviews in Magurran, 2004; Chao \& Shen, 2010; Colwell, 2013). Much effort has been put into resolving the problem of species-area-relationships and making sample units comparable, which have been addressed respectively by assuming an underlying abundance distribution and by adopting rarefaction methods (e.g. Condit et al., 1996; Gotelli \& Colwell, 2001; Dengler \& Oldeland, 2010). There are a number of alpha and beta diversity indices that produce conflicting results and which incorporate different sensitivities to species frequencies. Recent works have highlighted the use of true diversity measures. Jost $(2006,2007)$ introduced transformations of indices to effective numbers of 
species in order to produce stable and easily interpretable similarity measures. The concept of true beta diversity as a function of alpha and gamma diversity was reviewed by Tuomisto (2010a, 2010b).

\subsection{Taxonomic, functional and phylogenetic diversity of plant communities}

The majority of studies on the diversity and compositional structure of plant communities have taken taxonomic entities as focal units (mostly species, in studies of tropical ecosystems, often genera or families). However, species assemblages can also be characterised by traits and the phylogeny of the taxa (Webb et al., 2002). Accordingly, species assemblages, traits and phylogenetic histories are mechanistically related to each other (Fig. 1a).

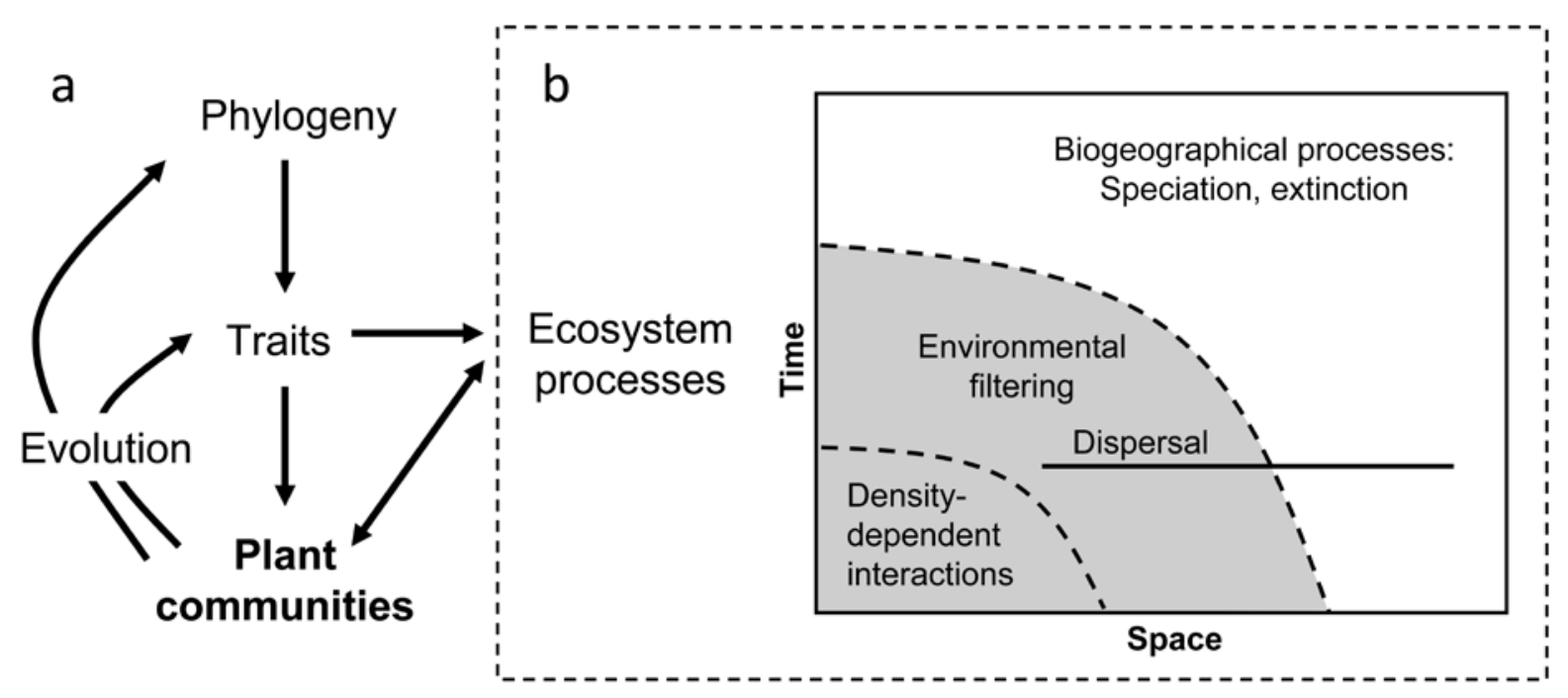

Fig. 1: The relationship of the varying aspects of plant diversity (taxonomic, functional and phylogenetic characteristics of plant communities) and ecosystem processes (ecological and biogeographical processes) in time and space: (a) Traits arise as innovations along the tree of life (evolution) and tend to be shared by species that have common ancestry (phylogenetic history). Traits play, in turn, a central role in ecosystem processes that influence the assemblage of species in plant communities. Hence, plant functional traits are a mechanistic link by which phylogenetic history influences ecosystem processes, and ecosystem processes within communities can again cause a feedback loop with evolutionary processes. (b) The ecosystem processes that drive the assemblage of species in plant communities operate over varying temporal and spatial scales. At the broadest spatial scale, species distributions are mainly determined by biogeographical processes that include speciation, extinction and dispersal; these processes occur over long temporal scales. Dispersal varies with the mobility of the organisms and can alter patterns of species distributions established through ecological sorting processes. At decreasing spatial scales, the environment (abiotic and biotic factors) filters out species lacking the (physiological) tolerances that permit persistence. Densitydependent interactions operate most intensively at neighbourhood scales. At a given spatial scale, the different ecological (grey-shaded) and biogeographical (white background) processes may act more or less strongly. This figure, including caption, was adapted from figures in Cavender-Bares et al. (2009). 
A biological trait is a well-defined, measurable property of any organism(s) that is usually measured at the individual level and used comparatively across species (McGill et al., 2006). Functional traits strongly influence the performance of organisms and cover fundamental biological trade-offs that determine a species' ecological role (Cornelissen et al., 2003; Westoby \& Wright, 2006) and provide insights into the associated community niche structure (Webb et al., 2002). Regenerative traits (dispersal mode, seed mass, seed shape and size) can provide information on the relative dispersal and competitive ability of different plant species. Other vegetative traits can offer insights into plant species' climate and $\mathrm{CO}_{2}$ responses (e.g. specific leaf area, leaf nutrient concentrations), disturbance response and

pest defence (e.g. growth form, clonality, wood density, bark thickness). Secondary ecological traits include information on the properties of the ecosystems in which the species occur (realized habitat, e.g. by Ellenberg Indicator Values, Ellenberg et al., 2001), plant strategy types (e.g. CRS system, Grime, 2001) and sensitivity to human impact (e.g. sensitivity to mowing or grazing, Dierschke \& Briemle, 2002; hemeroby, Klotz et al., 2002).

Studies in community ecology can be further informed by knowledge on the evolutionary relationship among co-existing species (Webb et al., 2002). Phylogenetic data, which are becoming increasingly available (Stevens, 2001 onwards; Davies et al., 2004), help in the interpretation of ecological patterns within and among communities. They can be used to assign conservation values to species assemblages (Faith, 1992), and to investigate whether ecologically relevant traits are phylogenetically conserved or convergent and over what temporal scales they have developed (Cavender-Bares \& Wilczek, 2003; Wiens \& Donoghue, 2004; Silvertown et al., 2006; Johnson \& Stinchcombe, 2007; Vamosi et al., 2008; Cavender-Bares et al., 2009; Cadotte et al., 2010, 2013; Srivastava et al., 2012).

\subsection{Ecosystem processes}

The second step in the examination of plant diversity is to elucidate the mechanisms that underlie the observed spatial patterns. There are three main perspectives on the factors that influence community assembly, diversity and composition (reviewed by Cavender-Bares et al., 2009). The first perspective is that communities assemble according to niche-related processes (Tilman, 1994), in which spatial or temporal heterogeneity cause local environmental filters and lead to competitive exclusion (spatial competition hypothesis; see also review by Silvertown, 2004). The most radical alternative theory is Hubbel's Unified Neutral Theory (Hubbel, 2001) which proposes that species are competitively equivalent, niche differences are irrelevant, and the presence, absence and relative abundance of species in assemblages are governed by random speciation and extinction, dispersal limitation and ecological drift. The third view emphasises the historical perspective in that it is a community concept based on interactions between populations over a continuum of spatial and temporal scales within entire regions, which includes populations beyond the habitat scale and considers evolutionary processes that produce new species (Ricklefs, 2008). In the latter perspective, the starting conditions and historical patterns of speciation and dispersal matter more than local processes.

For the present study, I follow-up on a fourth (unifying) perspective of Cavender-Bares et al. (2009), who addressed the relative role of the historical perspective as well as the neutral versus niche-related processes (Fig. 1b). They found that different processes of community 
assembly act most strongly at different spatial scales. There have been four ecological and evolutionary key processes identified: Density dependent interactions, environmental filtering, dispersal, and biogeographical processes (Webb et al., 2002, 2008; Ackerly, 2003; Chave, 2008; Cavender-Bares et al., 2009).

Density dependent interactions operate most intensively at neighbourhood and habitat scales under limiting coexistence conditions (Ricklefs, 2008). For plants, in particular, this includes processes of competition (Tilman, 1994; Chesson, 2000; Coomes \& Grubb, 2003; Silvertown, 2004), facilitation (Callaway \& Walker, 1997; Bruno et al., 2003; Sargent \& Ackerly, 2008) and herbivory (Milchunas \& Noy-Meir, 2002; Boege \& Marquis, 2005). Specifically, tropical plant ecology has historically focused almost exclusively on the mechanisms of local species coexistence (Chave, 2008), while less importance has been placed on intermediate- or large-scale patterns of diversity, hence the focus of the present thesis.

Environmental filtering refers to the differing success of populations or species resulting from their various functional characteristics in contrasting environments (Ackerly, 2003). The environment can include both abiotic factors (e.g. temperature, soil moisture, $\mathrm{pH}$, soil nutrient content) and biotic factors (e.g. pollinators, herbivores, anthropogenic pressure). These processes of environmental filtering converge with density dependent interactions at the habitat and local scales and mainly act on the local to continental scales. Vegetation ecologists have a long track record of predicting plant species and community occurrence from environmental characteristics, and a wealth of gradient analysis methods have been developed for detecting environmental correlations (see overviews by Legendre \& Legendre, 1998; Lepš \& Šmilauer, 2003; Oksanen, 2013).

Dispersal refers to the movement of individuals from their source location to another location where they may establish and reproduce (Nathan et al., 2008). In plants, adults are sessile and dispersal typically occurs as transport of seeds mediated by a biotic (animals) or abiotic (wind, water) vector. The majority of seeds are dispersed relatively short distances (neighbourhood to local scales) and long-distance dispersal is relatively rare (Nathan et al., 2008; Corlett, 2009a). Thus, dispersal varies with the mobility of the organisms and can alter patterns of species distribution established through ecological sorting processes (Vamosi et al., 2008). Highly mobile species are less likely to show a signature of their biogeographical history, whereas clades that contain species with more limited dispersal ability are likely to be clustered spatially (Cavender-Bares et al., 2009).

Biogeography should be understood as an "integrative discipline that combines phylogeny and ecology to address important questions about the distribution of lineages and global patterns of diversity" (Wiens \& Donoghue, 2004). Biogeographical processes include the evolutionary mechanisms of speciation and extinction (Johnson \& Stinchcombe, 2007), and the ecological mechanisms of dispersal (Vamosi et al., 2008). These usually occur over long temporal scales (macro-evolutionary timescales) and determine species distributions at the broadest, supra-regional spatial scales (Cavender-Bares et al., 2009). The analysis of plant community phylogenetic patterns can identify which species and traits evolved in-situ (leading to phylogenetic clustering, i.e. closely related species occur within the same habitat more often than by chance) versus those that evolved elsewhere and moved into the community (leading to phylogenetic overdispersion, i.e. closely related species occur within the same habitat less often than by chance; Wiens \& Donoghue, 2004; Johnson \& 
Stinchcombe, 2007). Genetic variation and evolution can shape the ecological properties of an entire community, and, in turn, ecological processes within a community can cause evolutionary processes and patterns (Fig. 1a). Such ecological-evolutionary feedback loops have been proposed to specifically occur in changing environments whereby a mismatch between a species' environmental tolerances and the environment it occupies is created, thereby creating opportunities for adaptive evolution (Ackerly, 2003).

\subsection{Examining the relationship of plant diversity and ecosystem processes at different spatial scales}

The following document is arranged in four main sections. Each section focuses on specific spatial scales at which varying aspects of plant diversity - including taxonomic, phylogenetic and functional characteristics of plant communities - are exemplarily investigated with a view to shedding light on the underlying processes that influence plant diversity patterns at each scale.

Chapter 2 presents an analysis of the biogeographical processes (speciation, dispersal limitation) along environmental climatic gradients across tropical mountain rain forests in the biogeographical region of Malesia. The spatial focus is centred on comparing tropical tree communities at the regional to continental scales. Intensive field studies were conducted in old-growth mountain rain forests of Sulawesi (Indonesia), which, despite being one of the most poorly known eco-regions of Southeast Asia, counts among the major biodiversity hotspots of the Palaeotropics. As such, a prerequisite for biogeographical studies in the region is the identification of plant collections to the species level, the description of new species and the mapping of species distributions. The major environmental filter investigated in our mountain forest transect study was the elevational gradient along which changes in the taxonomic and phylogenetic diversity occur compared to that of other mountain forests across Malesia (Borneo, Java and the Philippines). The unique biogeographical and phylogenetic structure of Malesian high-elevation forests was therefore explored and it was demonstrated that the origins of high mountain tree communities of Sulawesi can be ascertained from analysis of species distributions across the neighbouring islands of the Malesian archipelago.

Chapter 3 highlights the (often underestimated) importance of carbon stocks in tropical mountain rainforests, which were examined in relation to structural characteristics of the forests, functional traits and the biogeographical history of the tree species. The initial focus of our study was on the plot-based tree inventories of old-growth forests at the local and regional scales. At the regional scale, elevational changes of aboveground biomass were estimated for the aforementioned mountain forest transect study sites on Sulawesi island (Indonesia). One of the forest stands, a submontane forest (at $1050 \mathrm{~m}$ a.s.I.), was an experimental site of the Sulawesi Throughfall Experiment of the University of Göttingen, which provided additional, local-scale data on total above- and belowground biomass and stand productivity for an old-growth forest. The results of both old-growth mountain forest studies were then compared at the global scale to other plot-based transect and single-plot studies from the Palaeo- and Neotropics. An additional aspect was then added in that conclusions could be drawn on carbon releases associated with forest conversion by 
comparing total carbon pools and annual $C$ sequestration of the experimental old-growth forest with that of a further experimental agro-forest site.

Chapter 4 sets out in detail the methodological approaches adopted for predicting distribution patterns of ecologically valuable temperate forest communities by means of indicator species occurrences based on latitude-longitude grid-cells of c. $30 \mathrm{~km}^{2}$ in the area of northwest Germany. At the regional scale and under fairly homogeneous macro-climatic conditions and biogeographical history, environmental factors mainly influence community incidences, i.e. ecological barriers that limit the establishment and dispersal of characteristic species. For a first study, the presence of Natura 2000 forest habitats was modelled from plant distribution data. The predictive power of the indicator species assemblages selected was high, because the number of indicator species derived from classification using fidelity measures was narrowed down to species with a high forest affinity, which was used as an ecological trait of the species' realized habitats. For a second study, a new approach for the identification of supra-regionally implementable ancient woodland indicator plants was presented. A list of 67 'ancient woodland indicator plants' as a subset of the larger group of ancient woodland plants was compiled by systematically evaluating plant distribution data of floristic surveys in relation to ancient woodland cover data from state-wide inventories. Both approaches should contribute to a more systematic forest conservation planning, highlighting the importance of effective conservation management of ancient and near-natural forests in the landscapes of northwest Germany.

Chapter 5 presents a series of studies that investigated the influence of land use change on the taxonomic and functional diversity of agricultural ecosystems (grasslands and arable fields) in north and central Germany, with a focus on temporal changes at the local and regional scales. At the local scale, a case study from the rural district of Göttingen investigated present-day patterns in the diversity of dry and mesic grasslands and identified variations in plant community composition, species richness, biological traits (pollination) and ecological traits (Ellenberg Indicator Values). The diversity patterns were related to current management practices with the continuity of grassland habitats (history of the grassland sites with management dating back $>100$ years) being set as environmental factors and interpreted with respect to their spatial arrangement. Another regional-scale case study covered seven study areas of the northern German lowlands and compared current and historical vegetation surveys (samples and maps) of wet and mesic floodplain grasslands, spanning a time period of $>50$ years. General trends on landscape-related measures (e.g. habitat loss and fragmentation of ecologically-valuable target grasslands) and plot-related measures (e.g. changes in grassland species richness, species and functional trait composition) were derived from comparisons between study areas and interpreted in relation to management changes. Against the background of the recent intensification of agriculture due to energy cropping, another study on annual crop fields investigated the interrelationships between crop type, management intensity and light transmissivity (transmissivity for photosynthetically active radiation, TPAR) and their effects on farmland plant diversity at the habitat to regional scales. 


\section{Climatic gradients and biogeographical processes across Malesian mountain rain forests}

\subsection{Overview}

- Ecosystems explored: Tree communities of tropical old-growth mountain rain forests

- Study area: Lore Lindu National Park, Sulawesi (Indonesia); Malesia (SE Asia and SW Pacific)

- Spatial scales in focus: Regional, continental

- Grain of the individual unit of observation: 0.2 ha to 1.44 ha plots

- Diversity patterns investigated: (a) Community composition (tree species); (b) Bryophyte communities occurring on tree trunks with relation to tree species traits; (c) Effective taxonomic and phylogenetic diversities of tree communities (exponential of Shannon entropy; Whittaker's effective species turnover; community phylogenetic structure: NRI, NTI; phylogenetic beta diversity: beta-NTI); (d) Continental-scale tree species distribution patterns (distributions across the subdivisions of Malesia)

- Ecosystem processes examined: Environmental filtering (elevational = climatic/temperature gradient); biogeographical processes (speciation, dispersal limitation)

- Methodological advances: (a) Randomisation techniques for a standardised comparison of forest plots with different sampling sizes (area, individuals) developed; (b) Phylogeny of 204 tree genera occurring in tropical mountain forests across Malesia resolved; (c) Worked example of consistent and combined use of effective taxonomic and phylogenetic alpha and beta diversity measures given; (d) Biogeographical patterns along the elevational gradient analysed using geographical family distribution patterns and richness centres; (e) Phytogeographical pattern analysed by occurrence probabilities based on nearest neighbour distances using the subdivisions of the phytogeographical region of Malesia

- Key results and conclusions:

I. New tree species were described and new tree species distribution records were mapped for Sulawesi.

II. At the regional scale, an elevational transect study on tropical montane forests (from submontane to upper montane elevations) of Sulawesi showed distinct elevational distribution patterns of tree taxa (at the species, genus and family levels).

III. Bark traits of tree species play an important role in the formation of their colonizing bryophyte communities; tree species with a rough bark generally had a higher number of moss species and possessed some moss species that did not occur on trees with smooth bark.

IV. At the continental scale, the investigation of the relative importance of ecological (habitat specialization) and biogeographical (speciation, geographical dispersal limitation processes) factors revealed that: 
i. The primary factor determining diversity patterns of tree assemblages across Malesian mountain forests was elevation (gradient of decreasing temperature), whereas the influence of region (considering western and central Malesia) was surprisingly low; as such, the major clades of the contemporary mountain forest trees must have evolved before the formation of the Malay Archipelago (sympatric speciation).

ii. Taxonomic richness and phylogenetic alpha diversity exhibited opposite trends with elevation; while generic richness decreased with elevation, high-elevation forests showed a phylogenetic overdispersion, indicating convergent trait evolution.

iii. The upper montane forests of Sulawesi and Borneo were characterised by the dominance of Southern Hemisphere conifers that are capable of long-distance dispersal.

iv. The high-mountain flora of Sulawesi comprised both eastern and western Malesian elements, with the nearest neighbouring islands of Borneo and Maluku both sharing species with Sulawesi, which reflects the complex palaeogeography of the island. However, the unique upper montane forests of Sulawesi harboured a number of typical elements of Papuasia/eastern Malesia and the Philippines that did not occur at lower elevations, which may be a result of historical patterns of land connection and the emergence of mountain ranges.

\subsection{The study area Sulawesi and the Malesian context}

The island of Sulawesi is located in the centre of the phytogeographical region of Malesia, which includes nine subdivisions from Malaya to Papuasia (Fig. 2; Brummitt, 2001). The central part of Malesia, with the archipelago of Sulawesi, Maluku and the Lesser Sunda Islands, is also called Wallacea. It is positioned at the biogeographical crossroads between East Asia and Australasia (Wallace, 1869), and between the Laurasian and Gondwanan continents (Primack \& Corlett, 2005). Sulawesi has a long history of being a large oceanic island. Extremely high rates of plate convergence resulted in the island's current configuration of being partly Southeast Asian and partly Southwest Pacific in origin (Hall, 2009).

I conducted field studies in old-growth mountain rain forests of Lore Lindu National Park, Central Sulawesi, Indonesia. Tree inventories [all trees with a diameter at breast height (dbh) $\geq 10 \mathrm{~cm}$ ] were carried out on plots of $40 \times 60 \mathrm{~m}$ (0.24 ha). In addition, small trees (with a dbh of $2.0-9.9 \mathrm{~cm}$ ) were surveyed on subplots (0.06 ha per plot). Supplementary studies used in Culmsee \& Leuschner (2013, Fig. 2) were based on similar methods and met comparable climatic conditions, with all plots (sites) being located within the humid or perhumid tropics ( $0-2$ months per year with $<100 \mathrm{~mm}$ rainfall). The plots were distributed along a gradient of increasing elevation associated with a monotonic decline in air temperature of about $5.2 \mathrm{~K}$ per 1000 m elevation.

A number of differing elevational zonation concepts have been discussed for tropical mountains (e.g. van Steenis, 1972, 1984; Frahm \& Gradstein, 1991; Ashton, 2003; Körner et al., 2011). My study used four main elevational zones (colline: 400-850 m a.s.l.; submontane: 850-1500 m a.s.l.; montane: 1500-2500 m a.s.l.; and subalpine: > $2500 \mathrm{~m}$ a.s.I.) that accorded primarily with the classification system of van Steenis (1972). The 
delimitation of the colline forest zone was adopted from Cannon et al. (2007), who found a major transition in species assemblages between lowland and colline forests - which they called hill forests - at $400 \mathrm{~m}$ a.s.l. The submontane and montane zones can be further subdivided into submontane, lower montane, mid-montane and upper montane subzones (as used in Culmsee \& Pitopang, 2009; Culmsee et al., 2010, 2011).

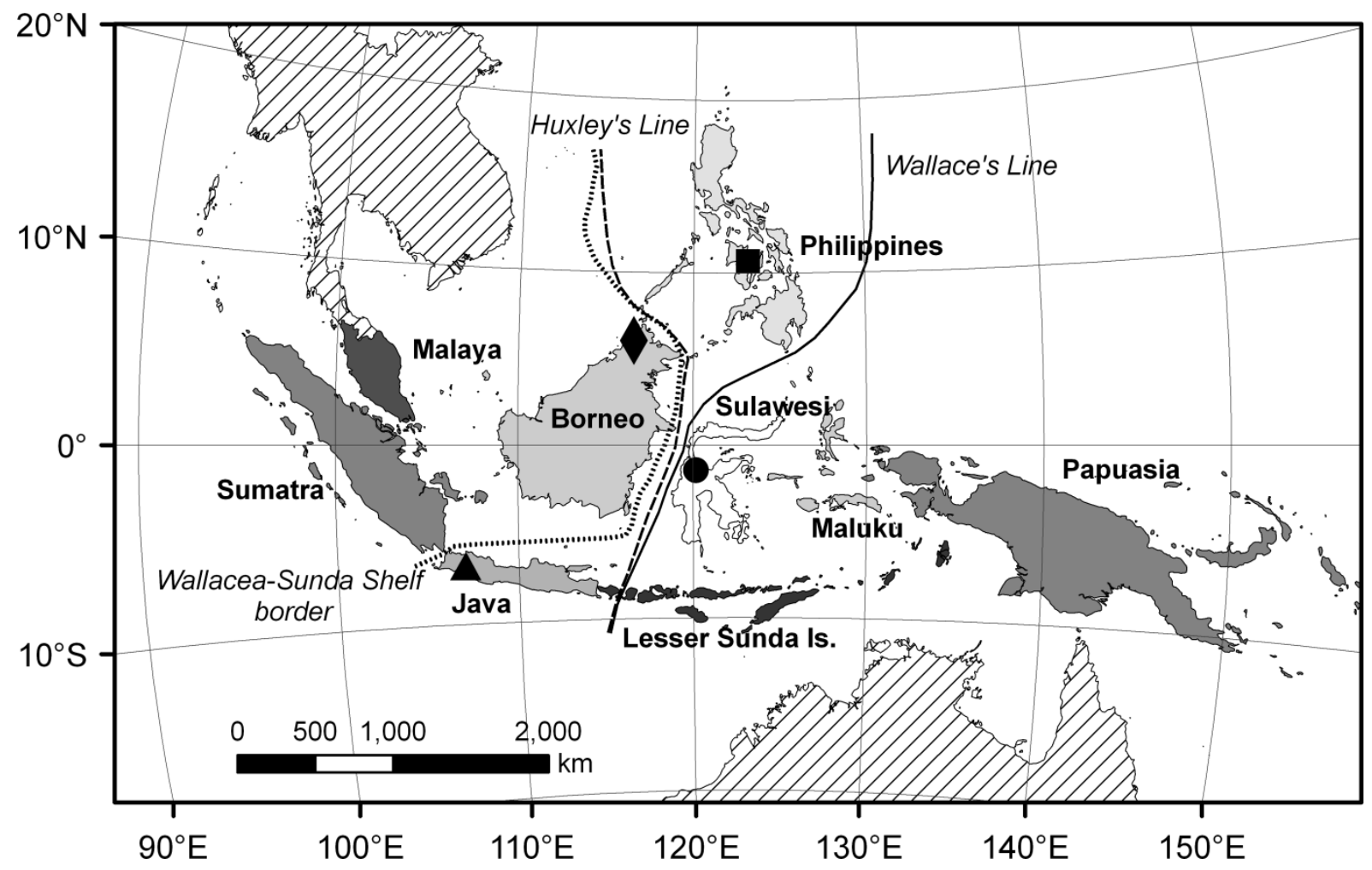

Fig. 2: The main study area in Sulawesi (circle), Indonesia, in the centre of the phytogeographical region Malesia which includes nine subdivisions from Malaya to Papuasia (after Brummitt, 2001). For diversity analyses across Malesia, supplementary published studies on mountain forests of Borneo (diamond), Java (triangle) and the Philippines (square) were used. Biogeographical boundaries are adopted from van Welzen et al. (2011) and mapped on Universal Transverse Mercator (UTM) projection 51 south (WGS 1984). This figure was taken from Culmsee \& Leuschner (2013).

\subsection{Linnean and Wallacean shortfalls}

Sulawesi counts among the major biodiversity hotspots of the Palaeotropics (Myers et al., 2000; Sodhi et al., 2004), but it is one of the most poorly known eco-regions of Southeast Asia (Cannon et al., 2007). As such, a prerequisite for biogeographical studies in this region are efforts to identify plant collections to the species level, the description of new species and the mapping of species distributions.

Although attempts have been made to further our knowledge on the occurrence of woody plants on Sulawesi (Keßler et al., 2002), the island remains seriously under-surveyed with regard to the highly diverse group of tropical trees. Before our surveys were initiated, a Dutch-Indonesian expedition to Mt. Rorekautimbu in 1979 (van Balgooy \& Tantra, 1986) was the only survey to have yielded a sizable collection of tree species from a high mountain peak of Central Sulawesi, which is now based at the National Herbarium of the Netherlands 
at Leiden ( $L$ ) and includes several species new to science. Indeed, many tree species have not yet been formally described or catalogued - a problem called the Linnean shortfall (Whittaker et al., 2005) - and among the $>3000$ specimens that we collected during our tree inventory survey in Lore Lindu National Park, Central Sulawesi (Culmsee et al., 2010), were several species that could neither be identified from available literature (floras, published and unpublished identification keys, primary descriptions, expert consultation), nor by comparison with herbarium material from Leiden. Some could be identified as new species of families that had already been systematically treated within Flora Malesiana (van Steenis, 19482010) or related studies. This resulted in the description of new species in Meliaceae (Culmsee, 2008), Moraceae (Berg \& Culmsee, 2011) and Magnoliaceae (Brambach et al., 2013). Others were identified as new species, such as a Reinwardtiodendron Koord. sp. nov. (Meliaceae), but a proper formal description was not feasible as flowers and fruit were lacking. Within the large group of Syzygium Gaertn. (Myrtaceae), only morpho-species were distinguished, as the detailed systematics of the group remain unsolved. However, of the 3,408 tree individuals that we surveyed during several field campaigns from 2006 to 2008 , 3,197 trees were identified to the species level (including 12 morpho-species of the Myrtaceae), 165 trees to the genus and 20 trees to family level, with less than $1 \%$ remaining unidentified (Culmsee et al., 2010).

With regard to species that are known, a second problem that applies to Sulawesi in that there is inadequate knowledge on the distribution of many taxa at various spatial scales - the so-called Wallacean shortfall (Whittaker et al., 2005). At the local scale, collections from mountain forest plots along elevational transects can lend insight into elevational distribution patterns of certain tree taxa (Culmsee et al., 2010; Culmsee \& Leuschner, 2013). At the regional and continental scales, through comparison with the 'Checklist of Woody Plants of Sulawesi' (Keßler et al., 2002), we revealed a large number of new records for Sulawesi or the Central Sulawesi province (see figures in Culmsee \& Pitopang, 2009; Culmsee et al., 2011). With new records for Central Sulawesi, it would be possible to close regional distribution gaps at the administrative level of provinces. One good example highlighting the implications of effective interpretation of the biogeographical history of taxonomic groups at the continental scale is an initial record developed for Dysoxylum acutangulum Miq. (Meliaceae) for Sulawesi (Culmsee, 2008). This record facilitated the completion of the species' distribution map based on the phytogeographical subdivisions of Malesia (cp. Fig. 2) and closed the distribution gap between the two subspecies in favour of Dysoxylum acutangulum Miq. subsp. foveolatum (Radlk.) Mabb. that occurs in the eastern parts of Malesia and Sulawesi.

\subsection{Tree inventories as a basis for the analysis of regional patterns in tree diversity along an elevational transect in Sulawesi}

Elevational gradients provide a natural experimental background for assessing the extent to which tree communities respond to gradual environmental change (Körner, 2007). In the humid tropics, the most ecologically important factor associated with increasing elevation is the monotonic decline in air temperature, which not only influences growth and respiratory processes in trees but also other components of the ecosystem, such as organic matter storage and decomposition (Letts et al., 2010). Assuming that declining temperature with elevation is a major driver of directional ecological sorting (sensu Ackerly, 2003), two 
complementary trends have been identified with regard to taxonomic diversity patterns in tree assemblages of tropical mountain forests (Culmsee \& Leuschner, 2013). First, the number of species, genera and families in tree assemblages decreases with increasing elevation (e.g. Gentry, 1988; Aiba \& Kitayama, 1999). Second, the rapid change in environmental conditions with elevation is associated with high taxonomic turnover along the slope. The marked shift in tree species composition is the basis for concepts of elevational floristic zonation of tree communities on wet tropical mountains (van Steenis, 1984; Ashton, 2003).

A set of papers reporting on our elevational transect study in Lore Lindu National Park, Sulawesi, covering an elevational range of approximately $1400 \mathrm{~m}$ from the submontane to the upper montane belt provide an overview of elevational changes in the abundance of tree taxa and the composition of tree assemblages occurring across 130.24 -ha plots in four oldgrowth forest stands (Culmsee \& Pitopang, 2009; Culmsee et al., 2010, 2011). The forests were highly species-rich, with 236 tree species from 62 families (Culmsee et al., 2010), and included a high number of unexpected distribution records and a number of new species (see Chapter 2.3). The submontane forest contained the largest number of families (42), with family numbers decreasing progressively with increasing elevation to a minimum of 26 in the upper montane forest. The elevational zones were characterised by distinct family distribution patterns. While magnoliids were most important at submontane elevations, eurosids I (including Fagaceae) were important at all elevations, but with the highest number of individuals occurring at mid-montane elevations and in co-dominance with tree ferns, Podocarpaceae, Trimeniaceae and asterids/euasterids II at upper montane elevations (Culmsee et al., 2010).

Because vegetation surveys and vegetation analysis approaches in temperate compared to tropical regions of the world meet fundamentally different conditions, a brief outline of the rarely documented differences is provided as follows:

First, plot-sizes are usually much larger in tropical than in temperate forest inventories. Phytosociological approaches use plots sizes of $100-400 \mathrm{~m}^{2}$ for sampling European forest vegetation (Chytrý \& Otýpková, 2003), which primarily covers a minimum area of the forest ground vegetation rather than the (relatively species-poor) tree layer. In comparison, the German National Forest Inventory uses angel-count sampling for tree inventories of larger forest stands with four systematic samples being taken on a squared track with an edge length of $150 \mathrm{~m}$ (BMELV, 2011).

In contrast, a standard size of 1 ha per plot is used most often for tropical lowland forest tree inventories (Corlett, 2009b). However, the CTFS permanent plots are sized at 16-52 ha (Condit, 1998), but the scope of these plots extends to the investigation of forest dynamics, which needs a larger area than that required for diversity studies. In tropical mountain forest tree inventories, using the appropriate plot size is crucial. On the one hand, high stem densities at upper elevations make surveying a 1 ha-plot unfeasible. On the other hand, the local tree species pool that is characteristic for the forest community should be sufficiently represented in the sample. Forest stand structure usually changes along elevational gradients, with a decline in mean tree diameter at breast height (d.b.h., at $1.3 \mathrm{~m}$ ) and mean tree height occurring with increasing elevation along with an increase in stem density (e.g. Liebermann et al., 1996; Aiba \& Kitayama, 1999; Moser et al., 2008). Such patterns were also observed along the elevational transect in Sulawesi (Culmsee et al., 2010). In elevational transect studies, species numbers are consequently not directly comparable 
when they are based on the same plot size, and the minimum area that is needed to represent the local tree species pool of a community is larger at lower than at higher elevations. This problem was solved by using a descending number of replicated plots (clusters of plots) in each of the four forest stands with increasing elevation (6, 3, 2 and 2 plots of 0.24 ha, i.e. a total area of 1.44-0.48 ha, from 1050-2400 m a.s.l.). Rarefaction analysis (Gotelli \& Colwell, 2001) was used to confirm that the sampled area at each elevational zone was sufficiently large to represent the tree species pool of the forest community (see Fig. 1 in Culmsee \& Pitopang, 2009; Fig. 2 in Culmsee et al., 2010). In addition, species richness can be projected to the standard size of a 1 ha-plot, which is used for lowland forest tree inventories as a fundamental measure of community richness. Based on a sample-based rarefaction analysis, the estimated number of tree species ha ${ }^{-1}$ (with $\geq 2$ $\mathrm{cm}$ d.b.h.) in our Sulawesi mountain forest plots was highest in the submontane forest (114 tree species ha- ${ }^{-1}$, Culmsee \& Pitopang, 2009) and steadily declined with increasing elevation (Culmsee et al., 2010, 2011).

Second, surveys may differ greatly in terms of the objectivity of species abundance measurements. In temperate forests, the relatively low number of tree species and the nature of the plant species assemblage of the forest floor usually allowed to be rapidly identified, and species abundances can be measured by more or less objective methods (Kent \& Coker, 1992). This may range from the most commonly used, but relatively subjective, estimation of percentage cover by eye (e.g. by using the Braun-Blanquet cover scale; BraunBlanquet, 1964) to more precise measures such as individual counts, as in the angle-count sampling method adopted for trees of the German National Forest Inventory (BMELV, 2011).

In contrast, tropical tree assemblages are inventoried to the individual based on the complete plot area, which is much more time consuming. This is necessary because species in the seemingly impenetrable forests are numerous and often not easily distinguishable. Usually, all tree individuals $\geq 10 \mathrm{~cm}$ d.b.h. in a plot are surveyed (see protocols in Condit, 1998) and, specifically in mountain forests, a subset of smaller trees is added ( $\geq 2-5 \mathrm{~cm}$ d.b.h.; e.g. Culmsee et al, 2010; Aiba et al., 2002). Each individual is visited and pre-identified (taking notes of characteristic bark, wood and leaf features and collection of reference material), with its position on the plot ( $X Y$ coordinates) and structural parameters (at least d.b.h. and tree height) being recorded. The individuals are usually permanently tagged in the first inventory, thus, individuals can be visited repeatedly (e.g. for the collection of flowering material) and plot dynamics can be monitored by re-census. In Germany, such an approach of tree individual-based permanent plots is only applied to total reserves and is then generally based on a systematic grid of circle-shaped plots of $0.05-0.10$ ha plot sizes (Meyer et al., 2001, 2007). However, such individual-based surveys offer the opportunity of applying randomisation techniques for a standardised comparison of forest plots with different plot sizes, as demonstrated by Culmsee \& Leuschner (2013).

Third, the number of forest vegetation data sets available differs tremendously, which leads to differences in the availability of opportunities to analyse data. Large databases have been created based on the rapid assessment techniques undertaken in temperate forest vegetation surveys. These provide opportunities for a consistent classification to be established (see Euroveg.org for examples of ongoing classification projects). For instance, a classification of temperate forests of Lower Saxony may review a set of 5,338 relevés available from literature (Culmsee et al., 2014). Although mostly at the species-level and considering all plant life-forms (but with the exception of mushrooms and epiphytic 
cryptogams), diagnostic taxa can be identified that delimit plant associations from the regional to the continental scales (Chytrý et al., 2002b). Phytosociologists have almost entirely catalogued Central European plant communities (e.g. Rennwald, 2000). Multivariate analyses on plant community-environmental relationships (recorded in parallel) are possible by using additional environmental data (e.g. soil values, management data) or existing trait databases (see Chapter 1.5).

In contrast, relatively few data sets on tropical forests are available as inventories are time consuming and expensive to establish in the field and they demand particular expertise in species identification. In addition, considering the overwhelming species richness of tropical forests, inventories are usually limited to one life form (e.g. trees) or even to a single large taxonomic group (e.g. palms; see Chapter 2.5). In our case, given the remoteness of the study area, access issues and tree density, it took a team of 7-10 botanists, technicians and tree climbers one to two weeks to sample trees across a single 0.24 ha plot. Thereafter, tree species identification took up to several months in some cases. However, the result is an analysis of well-elaborated mountain forest plots across 12 tropical mountain forests from western and central Malesia (Culmsee \& Leuschner, 2013), and the study can count toward more comprehensive tropical forest plot studies, such as a classification study of tropical lowland forests on Sundaland undertaken by Slik et al. (2011), which was based on survey results from 111 plots.

It is widely believed that Malesian rain forests are distinguished from other rain forests by the presence of plant genera with numerous coexisting species (Primack \& Corlett, 2005). The species-rich tree assemblages of our study also contained many speciose genera, with a high number of species found on only one plot (Culmsee \& Pitopang, 2009; Culmsee et al., 2011). Accordingly, species based beta-diversity analysis indicated a high dissimilarity between plots. There are several alternative means for describing the turnover of higher taxonomic levels along environmental gradients. The family importance value (FIV, Mori et al., 1983) can be used to assess the contribution of each family to a forest stand. FIV combines relative richness (number of species), relative density (number of individuals) and relative dominance (basal area) into one value. We described similarities between our plots using FIV (Culmsee \& Pitopang, 2009; Culmsee et al., 2011). The importance of families can alternatively be expressed by their aboveground biomass in a forest stand (Culmsee et al., 2010). It has been shown that floristic patterns of genera closely resemble those among species (Higgins \& Ruokolainen, 2004). We could therefore perform the analysis of the 12 mountain forest plots at the genus level (Culmsee \& Leuschner, 2013). Furthermore, phylogenetic diversity can be used instead of taxonomic diversity to reveal similarities between tree communities containing many closely related taxa (Webb et al., 2002, 2008; Culmsee et al., 2010; Culmsee \& Leuschner, 2013). 


\subsection{Studying diversity patterns of coexisting groups: The example of bryophyte communities occurring on tree trunks in relation to tree species traits}

Plant alpha diversity reaches extremely high levels in tropical forests, with species richness of trees $\geq 10 \mathrm{~cm}$ d.b.h. surpassing 200 species ha $^{-1}$ in Malaysia, Sarawak, Ecuador and Peru (Medina, 2007). Other plant life forms augment alpha diversity in tropical rain forests, where trees comprise just 25\% of the plant species (Wright, 2002). Because of such overwhelming richness, plant communities of tropical rain forests are usually investigated separately for different life forms (trees, herbs and ferns of the forest floor, ephiphytic bryophytes etc.), while other studies even focus on single large taxonomic groups (e.g. Palmaceae, Bromeliaceae). As such, diversity patterns of coexisting groups and their interactions are rarely studied comparatively in the same forest stand.

Bryophytes are an important component of moist tropical montane forests and, much like tree communities, bryophyte communities show distinct elevational zonation patterns (Frahm $\&$ Gradstein, 1991). Within the area of our intensively studied tree inventory plots (in a lower montane forest at $1400 \mathrm{~m}$ a.s.I. in Lore Lindu National Park, near Bariri village; Culmsee \& Pitopang, 2009), Prof. Dr. S.R. Gradstein sampled bryophyte assemblages occurring on tree trunks of randomly selected trees (18 trees $>20$ d.b.h., following Ariyanti et al., 2008). We combined the tree inventory and bryophyte survey data sets in a joint study (Gradstein \& Culmsee, 2010) in order to analyse the environmental influence of tree features on the assemblage of epiphytic bryophytes, an approach that had rarely been undertaken for tropical forests (e.g. Frahm, 1990). We found that bark traits of tree species played an important role in the formation of their colonizing bryophyte communities; tree species with a rough bark generally had a higher number of moss species and possessed some moss species that did not occur on trees with smooth bark.

\subsection{Analysing biogeographical processes across Malesian mountain forests}

Biogeographical processes occur over broad spatial and long temporal scales, and they involve dispersal, speciation and extinction (see Fig. 1 and Chapter 1.6; Cavender-Bares et al., 2009). In mountainous areas, another influential factor is land area, which gradually decreases towards mountain-tops, resulting in a relative geographical isolation of highelevation ecosystems that may be considered climatic or habitat islands (Körner, 2000). However, Ackerly (2003) argues that in contrast to isolated oceanic islands, such island-like montane or upper montane habitats can be continuous in environmental space, as colonizers can arrive from nearby habitats at lower elevations. In response to changing environmental conditions in the course of evolutionary history, populations may have experienced local shifts in their elevational distribution, large-scale changes in geographical distribution, adaptive evolution in response to new environments, or extinction (Ackerly, 2003).

Present-day patterns found in tree communities of tropical mountains should therefore reflect the prevailing biogeographical processes when analysed in a larger spatial context. Based on plot-based tree inventories conducted in Sulawesi, such large scale analyses have been performed using different methodological approaches. In an initial approach, ecological patterns within and among tree communities were interpreted in comparison to phylogenetic 
diversity patterns for a regional mountain forest transect in Sulawesi (Culmsee et al., 2010). In addition, an in-depth study at the continental scale was undertaken for 12 old-growth mountain forests of western and central Malesia, which included supplementary plot data from Borneo, Java and the Philippines (Culmsee \& Leuschner, 2013).

In order to measure phylogenetic diversity, the phylogeny of 204 genera occurring in tropical mountain forests across Malesia was resolved based on the angiosperm consensus tree (Davies et al., 2004), the APG3 megatree (Stevens, 2001 onwards) and a number of other published phylogenies (see detailed description in Culmsee \& Leuschner, 2013, with the Appendices S1 and S2 in the Supporting Information). The resulting Newick phylogeny was scaled to the estimated time of evolutionary origin using known family ages (Wikström et al., 2011). In an earlier study comprising transect plots in Sulawesi (Culmsee et al., 2010), Rao's quadratic entropy $\left(\mathrm{PD}_{\mathrm{Q}}\right.$; Rao, 1982) was used to describe the phylogenetic alpha diversity of forests stands. However, as discussed for taxonomic diversity measures (see Chapter 1.4), in the case of the analysis of phylogenetic communities, it is also imperative to use effective diversity measures in order to produce stable and easily interpretable results, especially if phylogenetic and taxonomic diversity measures are to be jointly interpretable. Therefore, in the later continental-scale study (Culmsee \& Leuschner, 2013), measures of standardized effect size were employed, which related the phylogenetic distances of taxa in a sample (where phylogenetic alpha diversity was measured) and among samples (where phylogenetic beta diversity was measured) relative to the phylogeny of the species pool (i.e. randomly generated null communities).

Phylogenetic community analyses revealed strong elevational changes in the patterns of tree assemblages both at the regional and continental scales (Culmsee et al., 2010; Culmsee \& Leuschner, 2013). In Sulawesi, larger phylogenetic clades showed distinct distributions, with the highest phylogenetic diversity occurring in upper montane elevations where basal clades (conifers, tree ferns, Austrobaileyales) met young clades (asterids/euasterids II). Effective taxonomic richness and effective phylogenetic alpha diversity exhibited opposite trends with elevation (see Fig. 2 in Culmsee \& Leuschner, 2013). While generic richness decreased with elevation, high-elevation forests showed a phylogenetic overdispersion, indicating a convergent trait evolution. Effective phylogenetic beta diversity analysis showed that the influence of region (considering western and central Malesia) was surprisingly low. We could therefore conclude that the major clades of the contemporary mountain forest trees must have evolved before the formation of the Malay Archipelago (sympatric speciation).

In a second approach, ecological patterns within and among tree communities were interpreted in the context of the distribution patterns of their component taxa. Using geographical family distribution patterns and richness centres (as described by Heywood et al., 2007), we found a progression from dominant tropical families at submontane elevations, to tropical Fagaceae at lower/mid-montane elevations, to conifers and Australasian endemics at upper montane elevations of the Sulawesi transect (see Fig. 5 in Culmsee et al., 2010). The unique biogeographical structure of the Sulawesi high-elevation forests was specifically explored by a new phytogeographical analysis approach (Culmsee et al., 2011). Using distribution records of the species across the phytogeographical regions of Malesia (Fig. 2) collated from published Floras and by checking herbarium collections, occurrence probabilities were calculated based on nearest neighbour distances of the Sulawesi mountain top forests to the other islands of the Malesian archipelago. It was shown that the high-mountain flora of Sulawesi comprised both eastern and western Malesian elements, 
with the nearest neighbouring islands of Borneo and Maluku both sharing species with Sulawesi, which reflects the complex palaeogeography of the island (Hall, 2009; see Chapter 2.2). However, the unique upper montane forests of Sulawesi had a number of typical elements of Papuasia/eastern Malesia and the Philippines. These may be interpreted as a result of historical patterns of land connection to the East and the relatively late emergence of mountain ranges (Spakman \& Hall, 2010; Stelbrink et al, 2012). In conclusion, these results strongly support Ackerly's (2003) biogeographical hypothesis of mountain-top communities being subject to continued colonization by taxa from lower elevations.

\subsection{Abstracts of original publications}

Berg, C.C., Culmsee, H., 2011. Ficus schwarzii redefined and two new species of Ficus (Moraceae) from Sulawesi (Indonesia) described. Blumea, 56: 265-269.

Ficus sulawesiana and F. gorontaloensis are described as new species and the description of $F$. schwarzii is emended. A modified key is included.

Brambach, F., Nooteboom, H.P., Culmsee, H., 2013. Magnolia sulawesiana described, and a key to the species of Magnolia (Magnoliaceae) occurring in Sulawesi. Blumea, 58: 271-276.

Magnolia sulawesiana is described as new species and a modified key of Magnolia subsect. Elmerrillia is included. In addition, a new key of the ten Magnolia species occurring in Sulawesi is provided based on vegetative characters for easy identification in the field.

Culmsee, H., 2008. Dysoxylum quadrangulatum, and notes on Meliaceae in Sulawesi. Blumea, 53: 602-606.

Dysoxylum quadrangulatum Culmsee (Meliaceae) is described as a new species from Sulawesi. Dysoxylum acutangulum Miq. subsp. foveolatum (Radlk.) Mabb. is reported as a new record for Sulawesi, closing the distribution gap between the two Western and Eastern Malesian distributed subspecies.

Culmsee, H., Leuschner, C., 2013. Consistent patterns of elevational change in tree taxonomic and phylogenetic diversity across Malesian mountain forests. Journal of Biogeography, 40: 1997-2010.

Aim: In order to investigate the relative importance of ecological (habitat specialization) and biogeographical (speciation, geographical dispersal limitation) processes as causes of non-random spatial distribution of tree species in the mountain forests of Malesia, we analysed the elevational change in the taxonomic and phylogenetic diversity of tree assemblages in different biogeographical subregions.

Location: Malesia (Borneo, Java, Sulawesi and the Philippines).

Methods: Tree inventory data of 12 old-growth forests from a wide elevational range (650$3080 \mathrm{~m}$ a.s.l.) were taxonomically harmonized and standardized (50 random draws of 245 individuals each per plot), and the phylogeny of 204 genera was resolved and scaled to its evolutionary origin. The taxonomic and phylogenetic diversities were calculated using effective generic measures, and the diversity patterns analysed by regression, ordination and classification. 
Results: The primary factor determining the diversity patterns of the tree assemblages was elevation, whereas the influence of region was surprisingly low. This results in common elevational patterns in taxonomic and phylogenetic community structure across western and central Malesia. The major clades of the contemporary mountain forest trees must therefore have evolved before the formation of the Malay Archipelago in its present form (sympatric speciation). Taxonomic richness and phylogenetic diversity exhibited opposite trends with elevation. Generic richness decreased linearly with elevation; the phylogenetic structure of high-elevation forests revealed overdispersion, indicating convergent trait evolution towards higher elevations, whereas the submontane and colline assemblages showed clustering with a considerable number of confamilials. The upper montane forests of Borneo and Sulawesi were characterized by the dominance of Southern Hemisphere conifers, which differentiated them from lower-elevation communities.

Main conclusions: Our results indicate that ecological, evolutionary and biogeographical processes (environmental filtering, sympatry and long-distance dispersal) have shaped the contemporary community structure of Malesian mountain forests. Wallace's Line may represent a significant barrier between the lowland tree floras of Borneo and Sulawesi, but this is not true for those at higher elevations. The uniqueness of high-elevation forests in terms of their high phylogenetic diversity and of their unusual structure calls for a high priority in conservation programmes.

Culmsee, H., Leuschner, C., Moser, G., Pitopang, R., 2010. Forest aboveground biomass along an elevational transect in Sulawesi, Indonesia, and the role of Fagaceae in tropical montane forests. Journal of Biogeography, 37: 960-974.

Aim: This study investigates how estimated tree aboveground biomass (AGB) of tropical montane rain forests varies with elevation, and how this variation is related to elevational change in floristic composition, phylogenetic community structure and the biogeography of the dominant tree taxa.

Location: Lore Lindu National Park, Sulawesi, Indonesia.

Methods: Floristic inventories and stand structural analyses were conducted on 13 plots (each $0.24 \mathrm{ha}$ ) in four old-growth forest stands at 1050, 1400, 1800 and $2400 \mathrm{~m}$ a.s.l. (submontane to upper montane elevations). Tree AGB estimates were based on d.b.h., height and wood specific gravity. Phylogenetic diversity and biogeographical patterns were analysed based on tree family composition weighted by AGB. Elevational trends in AGB were compared with other Southeast Asian and Neotropical transect studies $(n=7)$.

Results: AGB was invariant from sub- to mid-montane elevation (309-301 Mg ha)1) and increased slightly to $323 \mathrm{Mg}$ ha)1 at upper montane elevation. While tree and canopy height decreased, wood specific gravity increased. Magnoliids accounted for most of the AGB at submontane elevations, while eurosids I (including Fagaceae) contributed substantially to AGB at all elevations. Phylogenetic diversity was highest at upper montane elevations, with co-dominance of tree ferns, Podocarpaceae, Trimeniaceae and asterids/euasterids II, and was lowest at lower/mid-montane elevations, where Fagaceae contributed $>50 \%$ of AGB. Biogeographical patterns showed a progression from dominant tropical families at submontane to tropical Fagaceae (Castanopsis, Lithocarpus) at lower/mid-montane, and to conifers and Australasian endemics at upper montane 
elevations. Cross-continental comparisons revealed an elevational AGB decrease in transects with low/no presence of Fagaceae, but relatively high AGB in montane forests with moderate to high abundance of this family.

Main conclusions: AGB is determined by both changes in forest structure and shifts in species composition. In our study, these two factors traded off so that there was no net change in AGB, even though there were large changes in forest structure and composition along the elevational gradient. Southeast Asian montane rain forests dominated by Fagaceae constitute important carbon stocks. The importance of biogeography and species traits for biomass estimation should be considered by initiatives to reduce emissions from deforestation and forest degradation (REDD) and in taxon choice in reforestation for carbon offsetting.

Culmsee, H., Pitopang, R., 2009. Tree diversity in sub-montane and lower montane primary rain forests in Central Sulawesi. Blumea, 54: 119-123.

The tree diversity of sub-montane and lower montane primary forests is studied in plotbased inventories on two sites in Lore Lindu National Park, Central Sulawesi. Out of 166 species in total, $50 \%$ are new records for Sulawesi (19\%) or the Central Sulawesi province $(31 \%)$. Species richness decreases with altitude. In the submontane forest, the highest Family Importance Values (FIV) are reached by the Lauraceae, Fagaceae, Sapotaceae, Moraceae and Euphorbiaceae. In the lower montane forest, the Fagaceae are of major importance (FIV 71.9), followed at some distance by the Myrtaceae, Elaeocarpaceae and Lauraceae. For each site, a group of important families is identified that is of minor importance or absent on the other site. The comparison of basal area (BA), number of species and FIV with published plot-based studies in sub-montane and lower montane primary forests in Malesia (Borneo, Sulawesi, Papua New Guinea) reveals: 1) with 35.4 and $37.1 \mathrm{~m}^{2}$ ha-1, the BA is comparable to that measured in Borneo and Papua New Guinea, but does not support previous findings of extremely high BA in Sulawesi forests; 2) species richness is comparable to that in Borneo and other Sulawesi forests, but lower than in Papua New Guinea; 3) decrease in diversity with altitude is in accordance with findings in Borneo; 4) in sub-montane forests, the Lauraceae are generally important; the Sulawesi studies are closely related to those from Papua New Guinea; 5) the lower montane forests have the Fagaceae and Myrtaceae as most important families in common.

Culmsee, H., Pitopang, R., Mangopo, H., Sabir, S., 2011. Tree diversity and phytogeographical patterns of tropical high mountain rain forests in Central Sulawesi, Indonesia. Biodiversity and Conservation, 20: 1103-1123.

Tropical high mountain forests in Lore Lindu National Park, Sulawesi, Indonesia, were described by their floristic composition and the importance of tree families (Family importance values, FIV), based on tree inventories conducted on 4 plots (each $0.24 \mathrm{ha}$ ) in old-growth forest stands at c. 1800 and $2400 \mathrm{~m}$ a.s.l. (mid- and upper montane elevations). To identify general patterns and regional peculiarities of the forests in the SE Asian and SW Pacific context, the biogeography of the tree species was analysed using distribution records. Out of the total of 87 tree species, only 18 species were found at both elevational zones. The discovery of new species and new distribution records ( $28 \%$ of the data set) highlights the deficiencies in the taxonomic and distribution data for Sulawesi. Sulawesi endemism rate was $20 \%$. In the mid-montane Fagaceae-Myrtaceae forests, 
Lithocarpus spp. (Fagaceae) were overall important (4 spp. occupying around half of the total basal area) and the Myrtaceae the most species rich (8 spp.), thus showing typical features of Malesian montane forests. The upper montane conifer-Myrtaceae forest contained several high mountain tree taxa and showed affinity to the forests of New Guinea. The mountain flora comprised both eastern and western Malesian elements, with the nearest neighbouring islands Borneo and Maluku both sharing species with Sulawesi, reflecting the complex palaeogeography of the island. A separate analysis showed the midmontane forest to possess greatest biogeographical affinity to Borneo/western Malesia, and the upper montane forest had a number of typical elements of Papuasia/eastern Malesia and the Phillipines, which may be a result of historical patterns in land connection and the emergence of mountain ranges.

Gradstein, S., Culmsee, H., 2010. Bryophyte diversity on tree trunks in montane forests of Central Sulawesi, Indonesia. Tropical Bryology, 31: 95-105.

Previous studies have shown that submontane forests of Sulawesi harbor a very rich bryophyte flora, with more than 150 species occurring on eight canopy trees. We explore the relationships of trunk base bryophyte communities with elevation and tree characteristics (tree diameter, bark roughness) in montane forests of Sulawesi. The study showed that submontane, lower montane and upper montane forests of Sulawesi are characterized by very different bryophyte taxa. Calymperaceae, Fissidentaceae, Hypopterygiaceae, Lejeuneaceae, Leucobryaceae, Lophocoleaceae, Meteoriaceae, Neckeraceae, Porellaceae, Pterobryaceae, Radulaceae and Thuidiaceae are mainly found at low elevations, while Herbertaceae, Lepidoziaceae, Mastigophoraceae, Scapaniaceae, Schistochilaceae and Trichocoleaceae predominate at high elevations. Lejeuneaceae are the most important family in submontane and lower montane forests in terms of number of species, and Lepidoziaceae in upper montane forest. Plagiochilaceae are prevalent in lower montane forest. In general, species richness of liverworts increases towards higher elevation whereas moss richness decreases. Similar trends are observed elsewhere in the Tropics. Trunk community similarity decreases with distance and is about $25 \%$ between Sulawesi and Borneo, and virtually nil across continents. A few species showed a significant preference for rough bark but none for smooth bark. In general, trees with rough bark had more species than those with smooth bark. Trunk diameter correlated with the distribution of a few species but not with community composition or species richness. Our data are first statistically-supported evidence for bark roughness and trunk diameter specificity of bryophyte diversity in tree-species rich tropical forest. 


\section{Carbon pools of tropical montane forests from the local to global scales}

\subsection{Overview}

- Ecosystems explored: Tropical montane old-growth rain forests; cacao agroforests

- Study area: Lore Lindu National Park, Sulawesi, Indonesia (own field data); crosscontinental comparisons of tropical montane forests (literature data)

- Spatial scales in focus: Local, regional, global

- Grain of the individual unit of observation: 0.24-ha to 1.44-ha plots

- Diversity patterns investigated: (a) Regional patterns in tree aboveground biomass (AGB) of tropical montane rain forests in relation to forest structure, functional traits (wood density), floristic composition and phylogenetic community structure; (b) Elevational patterns of AGB in tropical montane forests in relation to the distribution of lineages in the Palaeo- and Neotropics; (c) Patterns in AGB, aboveground and belowground production of palaeotropical and neotropical (colline-)submontane forests; (d) Local patterns in below- and aboveground biomass and net primary productivity in a tropical submontane old-growth forest in comparison to a cacao agroforest

- Ecosystem processes examined: Environmental filtering, including (a) the elevational (= climatic/temperature) gradient, and (b) anthropogenic pressure (= forest conversion to agroforest); Biogeographical processes (by interpretation of global distribution patterns of the lineages)

- Methodological advances: Specific calculation procedures for estimating AGB of some taxa as a result of their distinct growth patterns and allometry developed for multi-stemmed Castanopsis acuminatissima Blume (Fagaceae) and for stranglers of the genus Ficus L. (Moraceae)

- Key results and conclusions:

I. At the regional scale of the Sulawesi transect, AGB was invariant from sub- to midmontane elevations (309-301 Mg ha ${ }^{-1}$ ) and increased slightly to $323 \mathrm{Mg} \mathrm{ha}^{-1}$ at upper montane elevations. While tree and canopy height decreased, wood specific gravity increased.

II. Cross-continental comparisons of palaeo- and neotropical montane forest studies revealed a decline in AGB with elevation in transects with a low/no presence of Fagaceae, but along transects with a moderate to high abundance of the family, a relatively high level of AGB prevailed. Southeast Asian montane rain forests dominated by Fagaceae constitute important carbon stocks. The importance of biogeography and species traits for biomass estimation should be considered by initiatives to reduce emissions from deforestation and forest degradation (REDD) and in taxon choice in reforestation for carbon offsetting.

III. The detailed local-scale study of the submontane forest of Sulawesi (divided into 6 subplots) showed that the mean total above- and belowground biomass was $303 \mathrm{Mg}$ 
$\mathrm{ha}^{-1}$ (or $128 \mathrm{Mg} \mathrm{Cha}^{-1}$ ). The total above- and belowground production was estimated at 15.2 $\mathrm{Mg} \mathrm{ha}^{-1} \mathrm{yr}^{-1}$ (or $6.7 \mathrm{Mg} \mathrm{C} \mathrm{ha}^{-1} \mathrm{yr}^{-1}$ ) with $14 \%$ of the stand total being invested belowground and $86 \%$ representing aboveground net primary production. The estimated aboveground biomass and production of this Fagaceae-rich forest stand was high in relation to the mean calculated for submontane forests at the global scale and much higher than for neotropical forests, but it was markedly lower than recorded for dipterocarp forests in Southeast Asia.

IV. The comparison of the total biomass and productivity of the submontane forest and a cacao agroforest on Sulawesi leads to the conclusion that the replacement of tropical moist forest by cacao agroforest reduces the biomass carbon (C) pool by approximately $130 \mathrm{Mg} \mathrm{C}^{-1}$; another $50 \mathrm{Mg} \mathrm{C}$ ha $^{-1}$ may be released from the soil. Further, the replacement results in a $70-80 \%$ decline in the annual $\mathrm{C}$ sequestration potential due to a significantly smaller stem increment.

\subsection{Estimating the aboveground biomass of tropical forests}

Guidelines have been published for setting up tropical forest inventory plots and for censusing trees (see Chapter 2.4; Condit, 1998). The conversion of plot census data into accurate estimates of aboveground biomass (AGB) stocks and productivity from these data sets includes several uncertainties in the estimation procedure, such as the choice of the best fitting regression model and the availability of measures for biomass calculation (Clark et al., 2001a, 2001b; Chave et al., 2004, 2005, 2006; Feldpausch et al., 2011).

The choice of the allometric regression model for converting tree structural data into AGB estimates is one of the most important sources of uncertainty in estimates of carbon stocks in tropical forests (Araújo et al., 1999; Chave et al., 2005). In a pantropical analysis of Chave et al. (2005), which included a large data set of 2,410 harvested trees from 27 study sites, wood-specific gravity, trunk diameter and forest type were identified as being the variables with the highest predictive power. The consideration of tree height further increased the accuracy of the models. A recent study of Feldpausch et al. (2011) stressed the importance of tree height. They found that the mean relative error in biomass estimates of destructively harvested trees when including tree height was half that when excluding tree height.

One of the most important components is wood-specific gravity $\rho$ (oven-dry weight, in $\mathrm{g} \mathrm{cm}^{-}$ ${ }^{3}$ ). Usually, instead of wood-specific gravity, a density value based on the mass of a sample at 12 or $15 \%$ moisture is given (Chave et al., 2006). Wood density has traditionally been regarded as a key functional trait. Bounded by 0.1 and $1.5 \mathrm{~g} \mathrm{~cm}^{-3}$, it describes the carbon investment or carbon storage per unit volume of a stem (Chave et al., 2009). Wood density is a taxonomically conserved trait (Baker et al., 2004; Slik, 2006; Swenson \& Enquist, 2007). Regional-scale patterns of tree species composition and associated wood density therefore define the variation of carbon content across environmental gradients (Baker et al., 2004; Malhi et al., 2006; Chave et al., 2009).

The AGB calculations of old-growth montane forests of Sulawesi used in Culmsee et al. (2010), Hertel et al. (2009) and Leuschner et al. (2013) adopted the most widely recognized equation used by Chave et al. (2005) for AGB estimation of wet forest stands. The analysis considered the bioclimatic conditions in the study area of Sulawesi (see Chapter 2.2) and 
included the available parameters of trunk diameter, total tree height and wood-specific gravity. Potential errors in AGB estimation were reduced by using specific calculation procedures for certain taxa with respect to their distinct growth patterns, including the multistemmed Castanopsis acuminatissima Blume (Fagaceae) and stranglers of the genus Ficus L. (Moraceae) (see details in Culmsee et al., 2010).

\subsection{The role of tropical montane forests as global carbon stores}

Tropical forests represent a substantial terrestrial carbon sink and play a key role in the global carbon cycle (Grace \& Meir, 2009). However, the magnitude of carbon stored and any regional variation is not well understood (Dixon et al., 1994; Clark et al., 2001b; Clark, 2004; Malhi \& Phillips, 2004; Chave et al., 2005). Syntheses on aboveground biomass (AGB) in Amazonian forests (Baker et al., 2004; Malhi et al., 2006; Saatchi et al., 2007; Baraloto et al., 2011; Quesada et al., 2012), African forests (Lewis et al., 2013) and Asian forests on Borneo (Paoli et al., 2008; Slik et al., 2010; Budiharta et al., 2014) have greatly increased our understanding of intact old-growth forest AGB variation across environmental gradients in the lowlands.

The amounts of AGB in tropical montane rain forests and changes in tree biomass carbon pools along elevational gradients have seldom been studied. While forest stand structure usually changes along elevational gradients, with a decline in mean tree diameter and mean tree height and an increase in stem density with increasing elevation (see Chapter 2.4), existing studies indicate that the pattern in AGB varies significantly along elevational gradients and between different tropical mountain ranges (Weaver \& Murphy, 1990; Lieberman et al., 1996; Raich et al., 1997; Kitayama \& Aiba, 2002; Wang et al., 2003; Moser et al., 2008; Culmsee et al., 2010).

In our regional-scale elevational transect study of tropical montane forests of Sulawesi (Culmsee et al., 2010), we found that AGB was invariant from sub- to mid-montane elevations (309-301 Mg ha ${ }^{-1}$ ), while it increased slightly to $323 \mathrm{Mg} \mathrm{ha}^{-1}$ at upper montane elevations. These results demonstrate a relatively large, but more or less invariant, carbon pool of intact old-growth montane forests on the mountains of Sulawesi. However, the AGB across different tree families showed significant elevational variation. For the first time, we related plot-level AGB estimates to phylogenetic (see Chapter 2.6) and biogeographical distribution patterns of tree families. Biogeographical patterns showed a progression from dominant tropical families at submontane elevations, through to tropical Fagaceae (Castanopsis, Lithocarpus) at lower/mid-montane elevations and to conifers and Australasian endemics at upper montane elevations (see Culmsee et al., 2010, Fig. 5). A crosscontinental comparison revealed declining AGB with elevation in transects with low/no presence of Fagaceae but relatively high AGB in montane forests with a moderate to high abundance of the family. Present-day genus-level diversity within Fagaceae is concentrated in the montane forests of Southeast Asia (Manos \& Stanford, 2001; Manos et al., 2008). In the Tropics outside Southeast Asia, Fagaceae play a similar ecological role in terms of AGB only in upper montane neotropical Quercus forests of Central America (see Culmsee et al., 2010, Fig. 6). Thus, the results of Spracklen \& Righelato (2014), who generally found relatively high $A G B$ in tropical mountain forests without considering regional trends along 
elevational or edaphic gradients and large continental-scale variations due to biogeographical patterns, have to be interpreted with care.

The study of Hertel et al. (2009) compared above- and belowground biomass and net primary productivity of the submontane forest of Sulawesi (i.e. the same submontane oldgrowth forest as in Culmsee et al., 2010) to other palaeotropical and neotropical natural forests. The AGB of the Sulawesi forest was found to be, on average, much higher than that of submontane forests in the Neotropics but lower compared to that of other submontane forests in the Palaeotropics, in particular when compared to dipterocarp forests in Malesia. This discrepancy may, on the one hand, be explained by the absence of Fagaceae in the Neotropics. On the other hand, Southeast Asian lowland to submontane forests of western Malesia dominated by ectomycorrhizal Dipterocarpaceae are generally taller than rain forests elsewhere (de Gouvenain \& Silander, 2003) and can achieve substantially higher AGB values (Paoli et al., 2008; Slik et al., 2010).

These exemplary personal field studies (Hertel et al., 2009; Culmsee et al., 2010) demonstrate that the AGB of tropical forests may be largely determined by the biogeography of the component clades of tree communities. The importance of biogeography and species traits for biomass estimates should therefore be considered by initiatives to reduce emissions from deforestation in developing countries (REDD) and in a suitable taxon choice in reforestation for carbon offsetting.

Tropical forests are exposed to large scale deforestation and degradation. In (sub)tropical Southeast Asia, more than $170.000 \mathrm{~km}^{2}$ of land was deforested for the period 2000-2010 (Kissinger et al., 2012). The main driver of deforestation was the conversion of forests for commercial and local/subsistence agriculture. Forest degradation was mainly (>80\%) driven by timber logging. Shearman et al. (2009) differentiated between deforestation of mountain forests in Papua New Guinea mainly related to subsistence agriculture, and deforestation of lowland forests that are commercially logged on a large scale. In particular, in remote frontier areas such as the mountainous regions of Central Sulawesi, expanding small-scale agriculture accounts for a large proportion of forest conversion (de Sherbinin et al., 2007). Conversion of natural or near-natural forests to agroforests, including cacao, is a key driver of forest conversion in this region (Koch, 2009).

Carbon storage in tree AGB is directly affected by deforestation and degradation. However, the magnitude of carbon released with the conversion of forests into various types of agriculture is poorly quantified (e.g. McGrath et al., 2000; Schroth et al., 2002). The local detailed study of Leuschner et al. (2013) investigated the implications of the conversion of submontane forests to cacao agroforests. The exemplary comparison of the total biomass and productivity of a submontane forest (as in Hertel et al., 2009 and Culmsee et al., 2010) and a cacao agroforest lead to the conclusion that the replacement of tropical moist forest by cacao agroforest reduces the extent of the biomass carbon (C) pool by approximately 130 $\mathrm{Mg} \mathrm{C} \mathrm{ha-1}$, while another $50 \mathrm{Mg} \mathrm{C}$ ha $^{-1}$ may be released from the soil. Further, the replacement results in a $70-80 \%$ reduction in annual C sequestration potential, due to the resultant significantly smaller stem increment. Our results on carbon losses with forest conversion to agroforest are higher than that typically reported in the literature where the subsoil is often ignored. This is further evidence for the outstanding role of natural forests for carbon sequestration in comparison to land use forms that replace them. 


\subsection{Abstracts of original publications}

Culmsee, H., Leuschner, C., Moser, G., Pitopang, R., 2010. Forest aboveground biomass along an elevational transect in Sulawesi, Indonesia, and the role of Fagaceae in tropical montane forests. Journal of Biogeography, 37: 960-974.

Please see Chapter 2.7.

Hertel, D., Moser, G., Culmsee, H., Erasmi, S., Horna, V., Schuldt, B., Leuschner, C., 2009. Below- and above-ground biomass and net primary production in a palaeotropical natural forest (Sulawesi, Indonesia) as compared to neotropical forests. Forest Ecology and Management, 258: 1904-1912.

Data on the biomass and productivity of southeast Asian tropical forests are rare, making it difficult to evaluate the role of these forest ecosystems in the global carbon cycle and the effects of increasing deforestation rates in this region. In particular, more precise information on size and dynamics of the root system is needed.

In six natural forest stands at pre-montane elevation (c. $1000 \mathrm{~m}$ a.s.I.) on Sulawesi (Indonesia), we determined above-ground biomass and the distribution of fine $(d<2 \mathrm{~mm})$ and coarse roots $(d>2 \mathrm{~mm}$ ), estimated above- and below-ground net production, and compared the results to literature data from other pre-montane palaeo- and neotropical forests.

The mean total biomass of the stands was $303 \mathrm{Mg} \mathrm{ha}^{-1}$ (or $128 \mathrm{Mg} \mathrm{C} \mathrm{ha}^{-1}$ ), with the largest biomass fraction being recorded for the above-ground components (286 Mg ha-1) and 11.2 and $5.6 \mathrm{Mg} \mathrm{ha}^{-1}$ of coarse and fine root biomass (down to $300 \mathrm{~cm}$ in the soil profile), resulting in a remarkably high shoot:root ratio of c. 17. Fine root density in the soil profile showed an exponential decrease with soil depth that was closely related to the concentrations of base cations, soil $\mathrm{pH}$ and in particular of total $\mathrm{P}$ and $\mathrm{N}$. The aboveground biomass of these stands was found to be much higher than that of pre-montane forests in the Neotropics, on average, but lower compared to other pre-montane forests in the Palaeotropics, in particular when compared with dipterocarp forests in Malesia. The total above- and below-ground net primary production was estimated at $15.2 \mathrm{Mg}$ ha-1 $\mathrm{yr}^{-1}$ (or $6.7 \mathrm{Mg} \mathrm{C} \mathrm{ha}^{-1} \mathrm{yr}^{-1}$ ) with $14 \%$ of this stand total being invested below-ground and $86 \%$ representing above-ground net primary production. Leaf production was found to exceed net primary production of stem wood. The estimated above-ground production was high in relation to the mean calculated for pre-montane forests on a global scale, but it was markedly lower compared to data on dipterocarp forests in South-east Asia.

We conclude that the studied forest plots on Sulawesi follow the general trend of higher biomasses and productivity found for palaeotropical pre-montane forest compared to neotropical ones. However, biomass stocks and productivity appear to be lower in these Fagaceae-rich forests on Sulawesi than in dipterocarp forests of Malesia.

Leuschner, C., Moser, G., Hertel, D., Erasmi, S., Leitner, D., Culmsee, H., Schuldt, B., Schwendenmann, L., 2013. Conversion of tropical moist forest into cacao agroforest: Consequences for carbon pools and annual C sequestration. Agroforestry Systems, 87: 1173-1187.

Tropical forests store a large part of the terrestrial carbon and play a key role in the global carbon (C) cycle. In parts of Southeast Asia, conversion of natural forest to cacao 
agroforestry systems is an important driver of deforestation, resulting in C losses from biomass and soil to the atmosphere.

This case study from Sulawesi, Indonesia, compares natural forest with nearby shaded cacao agroforests for all major above and belowground biomass $C$ pools ( $n=6$ plots) and net primary production ( $n=3$ plots). Total biomass (above- and belowground to $250 \mathrm{~cm}$ soil depth) in the forest (approx. $150 \mathrm{Mg} \mathrm{C} \mathrm{ha}^{-1}$ ) was more than eight times higher than in the agroforest (19 $\mathrm{Mg} \mathrm{C} \mathrm{ha-1).} \mathrm{Total} \mathrm{net} \mathrm{primary} \mathrm{production} \mathrm{(NPP,} \mathrm{above-} \mathrm{and}$ belowground) was larger in the forest than in the agroforest (approx. 29 vs. $20 \mathrm{Mg}$ dry matter (DM) ha ${ }^{-1}$ year $^{-1}$ ), while wood increment was twice as high in the forest (approx. 6 vs. $3 \mathrm{Mg} \mathrm{DM} \mathrm{ha}^{-1}$ year $^{-1}$ ). The SOC pools to $250 \mathrm{~cm}$ depth amounted to 134 and $78 \mathrm{Mg} \mathrm{C}$ $\mathrm{ha}^{-1}$ in the forest and agroforest stands, respectively.

Replacement of tropical moist forest by cacao agroforest reduces the biomass $\mathrm{C}$ pool by approximately $130 \mathrm{Mg} \mathrm{C} \mathrm{ha}^{-1}$; another $50 \mathrm{Mg} \mathrm{C} \mathrm{ha}^{-1}$ may be released from the soil. Further, the replacement of forest by cacao agroforest also results in a 70-80 \% decrease of the annual $\mathrm{C}$ sequestration potential due to a significantly smaller stem increment. 


\section{Regional plant diversity patterns in temperate forests of northwest Germany}

\subsection{Overview}

- Ecosystems explored: Temperate forests

- Study areas: The states of Lower Saxony, Bremen and Schleswig-Holstein, Germany

- Spatial scales in focus: Regional

- Grain of the individual unit of observation: Latitude-longitude grid-cells of $\sim 30 \mathrm{~km}^{2}$

- Diversity patterns investigated: (a) The composition of forest communities and associated diagnostic species across a spatial extent encompassing Lower Saxony (synopsis); (b) The predicted occurrence of Natura 2000 forest habitat types derived from cumulative distributions of forest community indicator species assemblages (richness per grid-cell) and proven forest habitat occurrences; (c) Distribution patterns of forest communities across natural landscapes (coast, lowlands, uplands) and their spatial configuration (Moran's I); (d) The distribution of 'ancient woodland indicator plants' as a subset of the larger group of 'ancient woodland vascular plants' and in relation to ancient woodland cover data on the lowlands of northwest Germany

- Ecosystem processes examined: Environmental filtering (a broad range of habitats mainly created by gradients in soil conditions and current and former land use practices, with fairly homogeneous macro-climatic conditions and biogeographical history); dispersal limitation (the low mobility of particular plant species that are not able to overcome barriers created by the spatial configuration of certain habitats, such as ecologically valuable forests and ancient woodlands in landscapes)

- Methodological advances: (a) A consistent classification of forest communities based on a large data set of 5,338 relevés from forests in Lower Saxony. This resulted in assemblages of indicator species derived using fidelity measures narrowed to species with high forest affinity, which was used as an ecological trait of the species' realized habitats; (b) The prediction of the distribution of Natura 2000 forest habitat types using large-scale, grid-based data sets on indicator species. These data are readily available from plant species monitoring programs, thereby providing a new approach for systematic conservation planning; (c) The identification of 'ancient woodland indicator species' that are valid at the regional scale, based on a systematic evaluation of plant distribution data of floristic surveys relating to ancient woodland cover using consistent and repeatable statistical methods

- Key results and conclusions:

I. Based on a state-wide review of vegetation survey data, 26 distinct forest communities were identified for Lower Saxony at the association level (including basal communities) according to the German vegetation classification system. Of these, 17 were assigned to 12 different ecologically valuable forest habitat types, as defined in the Natura 2000 habitat classification. 
II. The majority of the 17 ecologically valuable forest habitat types were well characterised by three or more indicator species with close affinities to forest habitats.

III. At the regional scale, the distribution of Natura 2000 forest habitats could be predicted from large-scale raster data on plant species distributions, for which only indicator species with close associations to forest habitats and high fidelity to single communities were selected.

IV. The success of the approach for localising Natura 2000 forest habitats was evidenced by ground-truth appraisals conducted in test areas with predicted, and thus far unknown, habitat occurrences.

$\mathrm{V}$. The method of predicting the distribution of forest habitat types using indicator species distributions is easily applicable to other European countries. This is because vascular plant monitoring programs are available in most regions, and it is possible to use large vegetation databases for qualitative information on community composition. The approach may facilitate a review of the existing Natura 2000 forest conservation network, be used to identify additional conservation areas or to monitor the success of forest conservation management measures.

VI. A list of 67 'ancient woodland indicator plants' was developed that is valid for the entire lowland area of northwest Germany.

VII. The widely applicable 'ancient woodland indicator plants' list may be a useful tool for future forest nature conservation. Potential applications include: (a) the identification of ancient woodlands in areas for which no historical maps are available, (b) the identification of biodiversity hotspots of ancient woodland indicator plants, and (c) locating ancient semi-natural woodlands. Ancient woodland habitats frequently contain a typical and rich forest biodiversity, and can often be regarded as biodiversity hotspots. Conservation management should therefore strongly focus on the preservation of remaining ancient woodlands and should inhibit the conversion of ancient woodlands to coniferous or mixed forests.

\subsection{Forest conditions and nature conservation value of forests in northwest Germany}

The complex landscape patterns of Central Europe have largely been formed by humans over thousands of years (Culmsee, 2013). While forests are the potential natural vegetation of more than $90 \%$ of the area of temperate Europe (Bohn et al., 2003), forest cover in Germany is approximately 11.1 million ha (31\% of the terrestrial area), which represents an increase in area by c. 1 million ha over the last four decades (BMELV, 2009). In spite of such gains, the conservation value of forests is continuously declining, because harvesting rates are high (40-60\% net harvesting rate in Germany for the year 2005) and the proportion of old-growth stands is critically low (EEA, 2010). In response, the 'National Strategy on Biological Diversity' (BMU, 2007) of the German Federal Government sets out a number of goals including: to protect $14 \%$ of the terrestrial area of Germany within the European Natura 2000 network by 2010; to allow $2 \%$ of the territory to naturally develop in large areas (wilderness areas), and to prevent commercial exploitation of $5 \%$ of the forests, allowing natural processes occurring largely undisturbed by 2020 . 
Among the German states, Lower Saxony and Schleswig-Holstein have the lowest forest cover. Only $11 \%$ of Schleswig-Holstein is covered by forest (BMEL, 2014). In Lower-Saxony, about $22 \%$ of the total area is forested; this ranges from $1 \%$ in coastal areas and $22 \%$ in the lowlands to a substantial 32\% in the uplands (Culmsee et al., 2014). Of the upland forests of Lower Saxony, 90\% are regarded as 'historically old' or 'ancient', i.e. current woodland has been continuously wooded since as early as the year 1800 (Glaser \& Hauke, 2004). In the Pleistocene lowlands of northwest Germany, the majority of woodlands (74\%) are conifer plantations, which are mostly established on infertile heathland, i.e. recent woodlands younger than c. 200 years. However, even deciduous stands on ancient woodland sites have been converted to conifer plantations or mixed forests, leaving only $7 \%$ of deciduous ancient woodland (Schmidt et al., 2014). Such ancient woodland habitats are mostly of high nature conservation value. In closely resembling the potential natural vegetation, they are often classified as Natura 2000 forest habitat types or other protected habitat types in accordance with national conservation law. Furthermore, they frequently contain a typical and rich forest biodiversity and can often be regarded as biodiversity hotspots. There are a number of vascular plant species that are closely linked to ancient woodlands (Hermy et al., 1999). Specifically, ancient woodlands provide sanctuaries for slowly colonising species that are typically characterised by low dispersal ability (Verheyen et al., 2003; Kimberley et al., 2013).

The European Union Habitats Directive (Council Directive 92/43/EEC) has played a large role in promoting nature conservation across Europe for the last 20 years. The goal to protect $14 \%$ of the terrestrial area of Germany within the European Natura 2000 network by 2010 is approaching completion. Despite these efforts, the 2010 target to efficiently protect habitats and species in Europe has not been reached (European Commission, 2011). The German National Habitats Directive Report (BfN, 2014) indicates that most of the forest habitats of the Atlantic region, which largely overlaps with the study area of northwest Germany, have remained in 'unfavourable-inadequate' or 'unfavourable-bad' condition since 2007, whereas the conservation status of oak forest types (habitat codes 9160 and 9190) and lichen-pine forests (habitat code 91T0) had deteriorated even further. Beech forests (habitat codes 9110 and 9130) have maintained an 'unfavourable-inadequate' conservation status in the Atlantic region but a 'favourable' conservation status in the larger Continental region of Germany (BfN, 2014). However, Germany bears responsibility for safeguarding beech forest ecosystems at the global level. The country is the biogeographical centre of Fagus sylvatica L. and covers about a quarter of the global distribution area of natural beech forest (BfN, 2008).

One of the reasons for such failure is that the selection of Natura 2000 areas has mostly not been based on systematic conservation planning; a conclusion drawn for the situation in Germany by Jedicke (2012). Reviewing the planning and implementation processes in European protected areas, Gaston et al. (2008) also came to the conclusion that although the Natura 2000 process has undoubtedly been the most important attempt to select additional protected areas across Europe, the program failed to properly exploit the full potential that a more systematic conservation planning approach could otherwise provide. A systematic approach would adopt strategic development options and consider locations of ecologically valuable habitats within the distribution ranges of the species and habitats beyond the existing Natura 2000 network of protected areas (as proposed by European Commission, 2006). With a view to addressing the shortfall, the EU Biodiversity Strategy to 2020 formulated the goal of integrating species and habitat protection into key land use 
policies both within and outside the existing Natura 2000 areas (European Commission, 2011). This target will likely result in the need to identify additional areas outside the protected areas where valuable habitats are present with reference to Annex I of the Habitats Directive.

\subsection{Advancing methodological approaches of identifying indicator species to facilitate systematic forest conservation planning}

Localising additional habitats with high ecological value can often be problematic, because adequate information is rarely available. In Germany, state-wide habitat mapping campaigns had already started in the 1980s before the establishment of the Natura 2000 protected areas network, but have not been updated. A deficit with respect to the identification of ecologically valuable areas beyond the actual Natura 2000 network has been identified, specifically for the states of Schleswig-Holstein and Lower Saxony (Kaiser et al., 2013). A possible option to address this deficit is high resolution remote sensing techniques, which can be employed for habitat mapping and for distinguishing habitat types even with relatively low levels of contrast (Nagendra et al., 2013). Remote sensing has been used for mapping the extent of forest cover and tree communities by identifying canopy trees to the species or genus levels (e.g. Bunting et al., 2010; Dickinson et al., 2013). The extent and degradation state of semi-natural habitats can be precisely mapped and monitored using satellite data, as shown for Wales, UK (Lucas et al., 2011). Remote sensing may however be less useful in the case of broad-leaved forests of temperate Europe, such as those considered in the Habitats Directive. These are characterised by only a few tree species and primarily by the herb layer, which cannot be identified by remote sensing techniques. Therefore, in addition to updating the state-wide habitat mapping, which is time consuming and costly, a possible practical solution to fill the information gap on potential forest conservation areas is to facilitate systematic conservation planning offered by models that predict habitat occurrences by means of indicator plant species distributions.

Systematic conservation planning requires clear decisions to be made on the features used as indicators of overall biodiversity (Margules \& Pressey, 2000). Two papers of this thesis provide detailed insight into such methodological approaches that aim to systematically predict distribution patterns of ecologically valuable forest communities across the large test region of northwest Germany. The first paper (Culmsee et al., 2014) presents new methods for modelling the distribution of Natura 2000 forest habitat types in relation to associated narrowly delimited forest community indicator species. The second paper (Schmidt et al., 2014) presents new methods for identifying ancient woodlands and forest biodiversity hotspots using ancient woodland indicator plants.

Both approaches use vascular plant species occurrences readily available on latitudelongitude grid-cells of c. $30 \mathrm{~km}^{2}$ covering the complete area of northwest Germany. Of the large vascular plant distribution databases, a selection of indicator species for ecologically valuable forest habitats was identified that corresponds to the objectives of the habitats of interest, i.e. Natura 2000 habitat types or hotspots of ancient woodlands.

Indicator species of Natura 2000 forest habitat types were derived from vegetation classification using fidelity measures, narrowed to species with high forest affinity (Culmsee et al., 2014). The EU approach of defining Natura 2000 habitat types largely adopts the 
methods of vegetation classification (Evans, 2010), but the interpretation of habitat types by diagnostic species is constrained by the spatial extent of the underlying data set (see also Chapter 1.3). It may range from the local scale to larger areas, and, correspondingly, the ranges of species available for classification can vary. Furthermore, the definition of indicator species is dependent on the scope of the planned comparison of habitats and communities. This either leads to the selection of characteristic species within a narrowly delimited forest community or within a synopsis of forest habitat types, or in the definition of species suitable for differentiating a forest community from other non-forest habitats. Criteria for defining indicator species should therefore be adapted to the specific context at the national or regional scales. As a benchmark approach, a regional classification of forest communities based on 5,338 phytosociological relevés recorded within the area of Lower Saxony and covering all naturally occurring forest communities was performed. First, characteristic species of each plant community were defined by means of fidelity measures in a synoptic table (Chytrý et al., 2002a; Tichy \& Chytrý, 2006; Tsiripidis et al., 2009). In order to eliminate those species with wide ecological ranges and frequent occurrence in non-forest habitats, the set of characteristic species was then narrowed to species that are closely bound to forest habitats according to the German Forest Vascular Plant Species List (Schmidt et al., 2011). Thus, the indicator species for specific communities were characteristic species in the sense of Braun-Blanquet (1964) with more or less exclusive occurrence in that association, while differential species used for separating related communities from each other were mostly excluded (see Fig. 1 in Culmsee et al., 2014). The majority of the 17 ecologically valuable forest habitat types, assignable to 12 Natura 2000 forest habitat types, was well characterised by three or more indicator species with close affinity to forest habitats. Threshold values required to ensure a high probability of occurrence in terms of cumulative numbers of indicator species necessary for each grid-cell were checked against habitat records derived from recent habitat surveys available for some selected areas and with that indicated in the literature ('ground-truth data'). Finally, the success of the approach for localising Natura 2000 forest habitats was evidenced by further ground-truth appraisals conducted in test areas with thus far unknown habitat occurrences.

Forest affinity was again one of the main criteria for the selection of 'ancient woodland indicator species' (Schmidt et al., 2014). According to Hermy et al. (1999), due to the distinct local variation in the ecological behaviour of forest plant species, regional lists of ancient woodland indicator plants are more appropriate than one Pan-European list. This point of view has been supported by numerous other authors (e.g., Rose, 1999; Wulf, 2004; Glaves et al., 2009; Perrin \& Daly, 2010). However, for the application of ancient woodland indicator lists (e.g. by nature conservation authorities or woodland surveyors), it is more convenient to cover larger areas at the regional scale in order to achieve enhanced validity and comparability. Of the group of forest plants, 'ancient woodland indicator species' valid for the region of northwest Germany were identified based on a systematic evaluation of plant distribution data from the available grid-based floristic surveys in relation to ancient woodland cover data using consistent and repeatable statistical methods. Whilst indicator species for Natura 2000 habitat types were identified based on phytosociological relevé data, ancient woodland indicator plants were identified based on their response to layers of ancient woodland cover data as indicative parameters. A consistent classification of all forest species considered for the study area $(n=390)$ resulted in seven groups, of which three were closely related to ancient woodlands of varying soil conditions. The necessary cross-validation for 
setting a threshold between 'ancient woodland indicator plants' (i.e. species with a high reliability of ancient woodland occurrences) and the larger group of 'ancient woodland plants' was performed by using ground-truth data of ancient woodland inventories available for some selected areas. The final list of 67 'ancient woodland indicator plants' is valid for the entire lowland area of northwest Germany.

Such data of vascular plant monitoring programs are available in most regions of temperate Europe (see Table 6 in Culmsee et al., 2014). It is possible to use large databases such as SynBioSys (Schaminée et al., 2007) or to find further data through the GIVD catalogue of vegetation databases (Dengler et al., 2011) for qualitative information on community composition. Furthermore, high-resolution data on historical and recent land cover are becoming increasingly available. Therefore, both approaches of identifying indicator species should be widely applicable to other large areas or countries, and should thereby contribute to a more systematic approach to forest conservation planning.

\subsection{Abstracts of original publications}

Culmsee, H., Schmidt, M., Schmiedel, I., Schacherer, A., Meyer, P., Leuschner, C., 2014. Predicting the distribution of forest habitat types using indicator species to facilitate systematic conservation planning. Ecological Indicators, 37: 131-144.

Recent assessments have identified significant shortfalls in the current Natura 2000 network approach for identifying protected areas throughout the European Union. A more systematic conservation network planning approach that adopts strategic development options and considers the occurrences of species and habitats within the distribution ranges of species across larger areas is needed in order to support decision making processes on the potential expansion, establishment and/or maintenance of conservation areas.

Using high-nature-value forest habitats across a large test region, i.e. the state of Lower Saxony in Germany, we developed a method aimed at systematically locating and appraising temperate forest habitats using indicator species distribution maps. Forest community indicator species were determined using forest habitat affinity criteria (derived from an existing database) and community fidelity (based on a review of 5338 vegetation relevés). Known habitat occurrences were derived from habitat surveys and relevant literature and were related to model data on indicator species distribution on a grid of 1739 raster cells (each $30 \mathrm{~km}^{2}$ ) using logistic regression.

The predictive power of the distribution models increased with the number of indicator species. However, tight correlations between indicator species distribution and habitat occurrence were only found when indicator species with a high affinity to forests were used exclusively. Field inspection of grid cells with outlying occurrences of five upland forest communities revealed several new forest habitat locations and led to greatly improved distribution models.

We conclude that the distribution of high-nature-value forest habitats can be predicted from large-scale raster data on plant species distributions when only indicator species with close association to forest habitats and a high fidelity to a single community are selected. Our approach may therefore facilitate a review of the existing Natura 2000 forest 
conservation network, be used to identify additional conservation areas or to monitor the success of forest conservation management measures.

Schmidt, M., Mölder, A., Schönfelder, E., Engel, F., Schmiedel, I., Culmsee, H., 2014. Determining ancient woodland indicator species for practical use: A new approach developed in northwest Germany. Forest Ecology and Management, 330: 228-239.

Ancient woodlands that have been in continuous existence for hundreds of years have a floristic composition which greatly differs from younger afforestations. The occurrence of certain associated vascular plant species, termed "ancient woodland indicator plants", can be used to recognise the continuity of woodland cover. Ancient woodland habitats frequently contain a typical and rich forest biodiversity and can often be regarded as "biodiversity hotspots". To pinpoint these habitats for nature conservation, there is a need to compile ancient woodland indicator lists with a widespread validity.

In this study, we introduce a new methodical approach that enables the compilation of such lists from the readily available resources of plant species monitoring programs, archive records, and land cover data. Using northwest Germany as a model region, we have developed an ecologically grounded list of 67 ancient woodland indicator plants for this area. In this context, we consider the "ancient woodland indicator plants" as a subset of the larger group of "ancient woodland plants".

The widely applicable ancient woodland indicator plants list presented here may be a useful tool for future forest nature conservation. Potential applications include: (a) the identification of ancient woodlands in areas where historical maps are lacking, (b) the identification of biodiversity hotspots of ancient woodland indicator plants, and (c) locating ancient semi-natural woodlands.

Finally, we highlight the importance of effective conservation management, which should seek to promote the typical plant diversity of ancient semi-natural woodlands. In doing so, conservation management should promote the preservation of remaining ancient deciduous woodlands and inhibit the conversion of ancient woodlands to coniferous or mixed forests.

Additionally, conservation management should strengthen the connections between recent and ancient woodlands through habitat corridors. Furthermore, careful forest management of deciduous ancient woodland sites with high typical woodland plant diversity has to be ensured to avoid soil damage. 


\section{The implications of land use change for the diversity of ecologically valuable grasslands and arable plant communities of annual crop fields in north and central Germany}

\subsection{Overview}

- Ecosystems explored: Managed temperate grasslands and arable plant communities of annual crop fields

- Study areas: The north German Pleistocene lowlands, the Lower Saxon hills and the Thuringian basin in the central German uplands

- Spatial scales in focus: Habitat, local, regional

- Time periods in focus: The present-day situation as compared to significant turning points that occurred over time in land use policy, including (a) the beginning of land use intensification in the end of the 19th century; (b) the advent of the European Union's Common Agricultural Policy in the former West Germany and, in parallel, the beginning of intensification campaigns in the former East Germany in the 1950/60s; (c) the recent rise in energy cropping since 2000

- Grain of the individual unit of observation: $16 \mathrm{~m}^{2}$ to $25 \mathrm{~m}^{2}$ grassland plots; varying sizes of grassland habitat patches within the landscape matrix of defined study areas; two plots of $100 \mathrm{~m}^{2}$ at the field margin and in the field interior of annual crop fields

- Diversity patterns investigated: (a) Grassland community composition, species richness and pollination types in relation to habitat continuity and current management; (b) The spatial extent and fragmentation of current and historical floodplain meadows, and the replacement of historical floodplain meadows by other land use types; (c) Temporal changes in floodplain grassland community composition, species diversity and functional trait composition based on historical and current vegetation samples; (d) Arable plant diversity (weed cover, species richness and species composition) within field, between fields, between crops and between regions in relation to light transmissivity and management intensity

- Ecosystem processes examined: Environmental filtering (habitat conditions created by former and current land use practices but with fairly homogeneous macro-climatic conditions and biogeographical history)

- Methodological advances: (a) An analysis of taxonomic and functional plant diversity patterns in grassland communities, resulting in spatially explicit quantitative data on grasslands with different ecological quality at the local scale. This is based on a stratified random sample of plots within a defined landscape in combination with historical land cover data, which are used for deducing the temporal perspective; (b) The quantification of changes in the area (total class area and percentage of the landscape) and spatial configuration (patch density, area-weighted mean of patch size and effective mesh size) at the level of grassland communities. This is based on historical and current high-resolution vegetation maps (scale c. 1:10,000) and by using 
repeatable geo-statistical methods; (c) A stratified random sampling approach for resampling historical phytosociological relevés, for which the exact location is unknown; (d) Linking light measurements in modern high-yield regular annual crop stands (not experimental stands) to the weed vegetation at local to regional scales using a systematic, replicated sampling design.

\section{- Key results and conclusions:}

I. At the local scale in the Lower Saxon hills, six grassland types ranging from speciespoor (<15 plant spp.) to extremely species-rich (>27 spp.) occurred under dry to mesic site conditions. Natura 2000 habitat types comprised only 1\% of the surveyed grasslands and medium-rich, high-nature-value grasslands a further 5\%. Grassland community composition was best explained by soil factors and species richness and pollination type composition by combined effects of current management and habitat continuity. The few ecologically valuable species-rich grasslands were all grassland remnants with $>100$ years of management continuity, i.e. dating back to the beginning of land use intensification in the end of the 19th century. Medium-rich Arrhenatherion grasslands were established primarily on less productive former arable fields $(<30$ years). While the number of wind-pollinated plant species was equal among all grassland types, there was a parallel decline in insect-pollinated plants and overall median species richness in the grassland communities along a gradient of increasing land use intensity (mowing, nutrient supply).

II. From the local-scale case study on the distribution and ecological quality of grasslands can be concluded that conservation efforts in such grassland-rich upland areas should focus on extant species-rich grassland types and should aim to implement traditional land use practices such as sheep grazing. Additional restoration efforts should focus on establishing new grasslands on less productive sites in the surroundings of speciesrich grasslands to facilitate seed dispersal, but nitrogen deposition should be buffered where appropriate. These measures would enhance the interaction between nature reserves and agricultural grasslands and thus improve the ecological quality of grasslands at the landscape scale.

III. At the regional scale in north and central Germany, unprotected floodplain meadows were investigated in 2008 in comparison to their past situation in the 1950/60s, i.e. the advent of the European Union's Common Agricultural Policy in the former West Germany and, in parallel, the beginning of intensification campaigns in the former East Germany. These floodplain landscapes showed alarming losses in the area of wet and species-rich mesic meadows in the past 50 years $(>80 \%)$. Wet meadows were largely fragmented, whilst changes in landscape structure were less consistent in mesic meadows. Wet meadows were mainly substituted by species-poor, intensively managed grasslands (26-60\%), and species-rich mesic meadows were mainly transformed to arable fields (42-72\%).

IV. The wet and mesic grasslands in unprotected floodplain areas surveyed at the plotlevel in the 1950/60s and resampled in 2008, showed tremendous changes in plant community composition, which was related to increasing Ellenberg Indicator Values for nutrient availability. The regional species pool was similarly large in the 1950/60s (299 spp.) and in 2008 (289 spp.), but species turnover was high with only 189 species observed in both censuses. Species richness at the plot-level decreased from a 
median of 27 species in the 1950/60s to a median of 19 in 2008, equivalent to losses by $30-50 \%$ over the period. Losses in functional diversity were equally large. The results indicate a consistent trend towards much more species-poor communities dominated by mowing-tolerant and $\mathrm{N}$-demanding competitive grasses. In contrast, species with more ruderal strategies, species flowering early in the season and, in particular, insect-pollinated herbs have all decreased.

V. Both studies on floodplain grasslands of north Germany document for the first time consistent trends in the loss and change of habitats and diversity of such ecosystems for a large region in the past 50 years. This urgently calls for high-priority conservation measures.

VI. Investigations of the arable plant diversity of conventionally managed annual crop fields, including maize and oilseed rape fields (mainly used as energy crops) and winter cereal fields (mainly used as food/fodder crops), in the uplands of central Germany clearly showed the extreme impoverishment of the field interior. This supported an average of five species per plot, with only very small differences in species richness between fields, and neither light availability nor crop type nor region explained this small variation. At the habitat scale, the soil surface of field margins experienced higher light levels than in field centres, and light availability was lowest in maize stands compared to other crop types. Maize fields contained fewer species than other crops at the field margin, which was probably related to higher levels of shading. Highest light transmissivity was measured on fields managed under an agri-environmental scheme (57\%), which was associated with elevated plant diversity (mean of $33 \mathrm{spp} .100 \mathrm{~m}^{-2}$ ).

VII. Regardless of crop type, the conventionally managed weed flora was generally impoverished. It was concluded that, on the landscape scale, the main effect of the recent expansion of energy cropping on farmland habitat diversity is the loss of extensively managed farmland where light availability is higher. Reduced fertilizer use on conventional field margins will increase light availability and thus improve habitat conditions for arable plant species.

\subsection{A brief historical outline of land use change in Central European rural landscapes}

Agricultural intensification has driven large-scale changes in the composition and structure of European landscapes (e.g. Gustavsson et al., 2007; Krauss et al., 2010; Flohre et al., 2011; Culmsee, 2013; Hötker \& Leuschner, 2014). This chapter discusses some of the issues surrounding the implications of land use change for plant diversity of agricultural ecosystems in Central Europe. It covers significant historical turning points in land use intensification, ranging from the time of traditional cultural landscapes (Plieninger et al., 2006) to that of the agro-industrial landscapes at present (Vos \& Meekes, 1999; BfN, 2010; Nitsch et al., 2012).

Rural landscapes today are the result of the variety of land uses that have overlaid, refined or replaced each other throughout history (Plieninger et al., 2006). The traditional agricultural landscape, in Europe widespread from Renaissance until the $19^{\text {th }}$ century (Vos \& Meekes, 1999), remains only locally. Traditional land uses include all "practices which have been out of fashion for many years and techniques which are not generally part of modern agriculture" 
(Bignal et al., 1995, cited in Plieninger et al., 2006). Most forms of traditional land use systems are characterised by relatively low nutrient input and relatively low output per ha. These are related to multiple low-intensity and rotational uses of common and private land, which often has created high spatial and temporal heterogeneity. They have mostly persisted in uplands or marginal areas where physical constraints have prevented a modernisation of agriculture. Because such remnants present species-rich, rare and endangered habitat types (e.g. heathlands, grasslands and low-input arable fields), most of them are extremely important for biodiversity conservation according to national law (BNatschG, 2009) and the European Union Habitats Directive (Council Directive 92/43/EEC).

During the period of industrialisation at the end of the $19^{\text {th }}$ century, land use practices became more intensive. Sheep farming declined, because the urban population developed a greater demand for cow milk, and wool of Australian origin and cotton conquered the German textiles market. The emergence of mineral fertilizers made agriculture more productive. While grasslands that were created by traditional pasturing and mowing over many centuries were dominated by grasses intermingled with herbs, this initial land use intensification exponentially accelerated the change in grassland community composition (Dierschke \& Briemle, 2002). Extensive grasslands changed to species-rich semi-intensive grasslands. In a local-scale study in the uplands of Lower Saxony (Krause \& Culmsee, 2013), we showed that the few semi-natural and species-rich meadows and pastures in the study area were all remnants of such grassland types that had persisted locally for more than 100 years.

Land use intensification further accelerated with the advent of the Common Agricultural Policy (CAP) in Western Europe in the late 1950s. Intensification campaigns followed in East Germany with a delay of about one decade (Bauerkämper, 2004). Despite the differences caused by the contrasting political systems, landscape composition and structure changed tremendously in both former German states as a result of intensification (Weiger, 1990). As a consequence thereof, intensively managed, species-poor grasslands, dominated by few productive grass species largely expanded over the following decades. In the local scale study in the Lower Saxon hills (Krause \& Culmsee, 2013), which have experienced an increase in grassland area since the late 1950s, specifically the extant mesic grasslands created between 1956/1962 and the early 1990s were mostly species-poor. However, in marginal areas, newly established grasslands had an intermediate species-richness. At the regional scale, wet and species-rich mesic floodplain meadows experienced dramatic losses in habitat area, species-richness of characteristic species and functional diversity since the 1950/1960s (Krause et al., 2011; Wesche et al., 2012).

Land use intensification since the 1950s was identified as being responsible for increasing habitat degradation and biodiversity loss (Stoate et al., 2001). Dramatic losses were evidenced for north and central Germany for grasslands (Krause et al., 2011; Wesche et al., 2012) as well as for arable weed communities (Meyer et al., 2013). The CAP was reformed in several stages from the late 1980s until the European Union Agenda 2000 (Henle et al., 2008), and has now resulted in an additional CAP reform with a 2014-2020 perspective (EU, 2013). However, it is unlikely that 'greening' as the present form of agricultural subsidies will be sufficient to stop the ongoing tremendous losses of biodiversity in Germany's agricultural landscapes (Hötker \& Leuschner, 2014). Meanwhile, the recent rise in energy cropping since 2000 has again increased pressure on farmland biodiversity. Germany, currently the largest producer of energy crops in the EU (Don et al., 2012), has declared an ambitious agenda for 
the transition from fossil to renewable energies, the so-called 'Energiewende' (BMU \& BMELV, 2010), and the government is pushing the transition with strong financial support (Britz \& Delzeit, 2013). As a consequence, the area cultivated with energy crops in Germany tripled from less than 0.7 million ha in 2000 to c. 2.1 million ha in 2012, equalling about $18 \%$ of the arable land (FNR, 2013a). This rapid expansion is currently mostly related to annual ('first-generation') energy crops ( $>90 \%$ of all energy crops grown on farmland) as these can be cultivated and handled with well-established, widely available machinery (FNR, 2013a, b). The two major energy crops in Germany are maize (Zea mays L.) and oilseed rape (Brassica napus L.) (FNR, 2013a, b). In 2012, maize for biogas production (representing 32\% of the total maize acreage) was grown on approximately $7 \%$ of the arable land, and oilseed rape for biofuel and vegetable oil (representing $70 \%$ of the total rapeseed acreage) was grown on $8 \%$ of the arable land (Destatis, 2013; FNR, 2013a,b). Political strategies project that the proportion of land used for energy crop cultivation might increase up to $34 \%$ by 2020 (BMU \& BMELV, 2010). It is assumed that this fundamental change in crop frequencies and land use intensity will also alter the environmental conditions determining the biodiversity in bioenergy landscapes. Therefore, in a regional study in the central German uplands (Seifert et al., 2014) we investigated the inter-relationships between crop type, management intensity and light transmissivity and their effects on arable plant diversity from the habitat to regional scales. We found a generally impoverished conventionally managed weed flora, regardless of energy or food/fodder crop types. We concluded that the main detrimental effect of the recent expansion of energy cropping on farmland habitat diversity is, on the landscape scale, the loss of extensively managed farmland where light availability is higher. Reduced fertilizer use on conventional field margins will increase light availability and thus improve habitat conditions for arable plant species.

\subsection{Analysing temporal changes in plant diversity patterns at different spatial scales}

Temporal changes in plant diversity can be detected by a monitoring scheme, which is defined as the repeated survey of vegetation patterns and processes and the comparative evaluation of the recorded data sets (Hellawell, 1991). Such a temporal comparison of vegetation can be based on land cover data (e.g. vegetation maps), plant species lists for a defined area or vegetation plots. Detailed and spatial referenced vegetation data have been becoming increasingly available over the last two or three decades due to the emergence of remote sensing techniques (e.g. Inse, 1995; Weiers et al., 2004; Wozniak et al., 2009), systematic state-wide habitat mapping campaigns (see an overview for Germany in Kaiser et al., 2013), plant species monitoring programs (see chapter 4.3; Table 6 in Culmsee et al., 2014) and the installation of regional (e.g. the ecological area sampling of 170 randomly selected sites in North Rhine-Westphalia, established in 1997) or even supra-regional permanent plot networks (e.g. The Long Term Ecological Research Network, established in 1980). However, long-term studies based on detailed ground-truth vegetation data that refer to the time before agricultural intensification ( $>50$ years ago) have rarely been conducted, mainly because historical spatially explicit vegetation data are rare (Prach, 2008). Especially the lack of replicated studies at multiple locations, which include detailed spatial information, is a major shortcoming. 
For analysing temporal changes in plant diversity related to land use change from the time period before agricultural intensification until today, we applied two approaches.

In a first approach, for the regional-scale study of changes in wet and species-rich mesic floodplain meadows since the 1950/60s, we used historical and recent vegetation maps (Krause et al., 2011) and vegetation plots (Wesche et al., 2012). Chytrý et al. (2014) tested different approaches for assessing vegetation change using vegetation plot databases, and concluded that re-visitation studies of historical phytosociological plots may be the best strategy to assess past vegetation change, while new networks of carefully stratified permanent plots are preferable for monitoring future change. We used seven original studies conducted according to the phytosociological approach of Braun-Blanquet (1964), but by different authors and based on different classifications as mapping units and varying plot sizes. Furthermore, the exact spatial location of the historical plots was not permanently marked. Therefore, it was necessary to apply data standardisation and harmonisation procedures and to develop standardised resurveying procedures. The phytosociological system has experienced major changes over the past decades and different underlying classification schemes had been applied in the seven areas. Therefore, we decided to standardise the habitat categories identified in the historical vegetation maps using a widely applied key for habitat surveys developed by nature protection agencies in Germany (von Drachenfels, 2004). The habitat key was used in the historical maps and was also applied in the resurvey. The historical and recent vegetation maps were then digitised using the standard map resolution (scale c. 1:10,000) and were analysed by using repeatable geostatistical methods (McGarigal et al., 2002). Since the exact location of the historical vegetation relevés was not known, we applied a stratified random sampling approach for resampling. In addition, particularly species-rich meadow stands were selected in a similar manner as had been practised in historical surveys (Chytrý, 2001). Our relevés thus included both average and particularly well-developed (species-richer) grassland stands, ensuring that observed effects were not solely caused by artefacts introduced by concentrating on extreme samples alone (Palmer, 1993). The two data sets showed qualitatively similar trends, and we thus reported results from both randomly and deliberately positioned relevés together.

In a second approach, for the local-scale study on mesic and dry grasslands in the Lower Saxon uplands (Krause \& Culmsee, 2013), we applied a space-for-time substitution procedure. At the landscape scale, quantitative conclusions on ecologically valuable habitats could be drawn from stratified random sampling of plots within a defined landscape using the geo-statistical approach of mass point triangulation. Furthermore, in combination with spatially explicit historical land cover data (historical maps), conclusions could be drawn on the temporal perspective. As spatial autocorrelation can be problematic in the interpretation of results especially in studies at the local scale, the spatial structure of the vegetation data was decomposed using advanced variation partitioning techniques (Borcard \& Legendre, 2002). This made it possible to interpret present-day vegetation data in relation to land use change over the last $>100$ years. A similar approach was also applied to the analysis of arable plant diversity in relation to light transmissivity and management intensity in bioenergy landscapes (Seifert et al., 2014). Within the relatively recent bioenergy landscapes, crops for biofuel versus food/fodder production were investigated in parallel, and predications of changes were made based on probable future developments. 


\subsection{Abstracts of original publications}

Krause, B., Culmsee, H., 2013. The significance of habitat continuity and current management on the compositional and functional diversity of grasslands in the uplands of Lower Saxony, Germany. Flora, 208: 299-311.

There is a growing concern that land use intensification is having negative effects on semi-natural grass-lands and that it leads to a general loss of biodiversity among all types of formerly extensively managed grasslands of poor to medium nutrient richness. Since the 1950s, many Central European uplands have been subject to an increase in grassland cover as a result of changes in land use practices. Using such a landscape in Lower Saxony, Germany, as a model region, we assessed environmental factors that control grassland diversity, including plant community composition, species richness and pollination trait com-position. In 2007, 189 vegetation sampling sites were randomly distributed among grasslands covering some 394 ha within a 2500 ha study area. Plant communities were classified using TWINSPAN and the effects of environmental factors (soil, topography, current management and habitat continuity) were analysed by canonical correspondence analysis and regression analysis reducing for the effects of spatial autocorrelation by using principal coordinates of neighbour matrices.

We found a wide range of six species-poor ( $<15$ plant spp.) to extremely species-rich ( $>27$ spp.) grassland types under mesic to dry site conditions, including sown, Cynosurion, Arrhenatherion and semi-natural grasslands. Grassland community composition was best explained by soil factors and species richness and pollination type composition by combined effects of current management and habitat continuity. During the 1950/60s, the extent of grassland area within the studied landscape rapidly increased to more than double its previous extent, and in 2007, grasslands comprised 16\%. Natura 2000 grassland types comprised $1 \%$ of the surveyed site and medium-rich, high-nature-value grasslands a further $5 \%$. While the number of wind-pollinated plant species was equal among all grassland types, there was a parallel decline in insect-pollinated plants and overall median species richness in the grassland communities along a gradient of increasing land use intensity (mowing, nutrient supply). Moreover, insect-pollinated plants occurring in intensively managed grasslands were found to additionally have the ability for self-pollination. Species-rich grasslands - including semi-natural grasslands and a semiimproved, species-rich Arrhenatherion community - occurred exclusively on old sites (with $>100$ years of habitat continuity) that had been used for traditional sheep grazing (environmental contracting).Medium-rich Arrhenatherion grasslands were established primarily on less productive, formerly arable fields ( $<30$ years). We conclude that conservation efforts should focus on extant species-rich grassland types and should aim to implement traditional land use practices such as sheep grazing. Additional restoration efforts should focus on establishing new grasslands on less productive sites in the proximate surroundings of species-rich grasslands to facilitate seed dispersal, but nitrogen deposition should be buffered where appropriate. These measures would enhance the interaction between nature reserves and agricultural grasslands and thus improve the ecological quality of grasslands at the landscape scale. 
Krause, B., Culmsee, H., Wesche, K., Bergmeier, E., Leuschner, C., 2011. Habitat loss of floodplain meadows in north Germany since the 1950s. Biodiversity and Conservation, 20: 2347-2364.

Floodplain meadows are severely threatened by land use change and intensification in Central Europe. This study investigates quantitative and qualitative changes in the vegetation of wet and species-rich mesic meadows in the floodplains of north Germany since the 1950s, considering their spatial extent, fragmentation, and replacement by other land use types. Historical high-resolution vegetation maps were compared with recent vegetation surveys in seven study regions (six unprotected areas, one protected reference area) in the former West and East Germany.

The unprotected sites showed alarming losses in wet and species-rich mesic meadows in the past 50 years $(>80 \%)$. Wet meadows were substituted by species-poor, intensively managed grasslands (26-60\% of the former area), arable fields (0-47\%) or set-asides (2$33 \%)$. Species-rich mesic meadows were transformed to arable fields (42-72\%) or species-poor, intensively managed meadows (14-72\%). Decreases in effective mesh size and patch size indicated increasing fragmentation of wet meadows, whilst changes in landscape structure were less consistent in mesic meadows. Only slight changes in the protected floodplain study area indicate that landscape change is mostly caused by local effects such as fertilisation and drainage, but not by general trends such as atmospheric $\mathrm{N}$ deposition or climate warming. Despite the contrasting political systems in West and East Germany with different agroeconomic frames, all unprotected study areas showed similar losses and increasing fragmentation of floodplain meadows, which may negatively influence the natural dynamics of, and the gene flow between, meadow plant populations. We conclude that floodplain meadows in north Germany urgently call for high-priority conservation measures.

Seifert, C., Leuschner, C., Meyer, S., Culmsee, H., 2014. Inter-relationships between crop type, management intensity and light transmissivity in annual crop systems and their effect on farmland plant diversity. Agriculture, Ecosystems and Environment, 195: 173182.

The recent boost of energy cropping in Central and Western Europe has greatly increased the demand for farmland leading to rapid land use change in many cultural landscapes. First-generation energy crops are now cultivated at more than $15 \%$ of Germany's arable land, but the consequences of this change in crop frequencies for agro-biodiversity are largely unknown. Concerns have been raised that this development might accelerate biodiversity loss due to high crop cover and reduced light availability in energy crop stands, which could further deteriorate the growing conditions for declining arable plant species.

We analysed the transmissivity for photosynthetically active radiation (TPAR) in conventionally managed maize and oilseed rape fields (energy crops) and winter cereal fields (food/fodder crops) in Central Germany and contrasted it with TPAR measured in wheat fields managed according to agri-environmental schemes (AES). Secondly, we analysed the relation between light intensity and arable plant diversity metrics with respect to effects of field management and geographical differences. 
Light availability was lowest in maize stands (6\% TPAR), followed by winter cereals and oilseed rape (10-13\%). Field margins were brighter than field centres (17\% vs.10\%). Highest light transmissivity was measured on AES fields (57\%), which was associated with elevated plant diversity. Light availability explained a significant fraction of the variation in species richness also on conventionally managed field margins ( $r 2=8 \%$ ). Effects of light availability on community composition were found only when the least intensive systems (margins of conventional and AES wheat fields) were analysed.

The main detrimental effect of the expansion of energy cropping on farmland habitat diversity is the loss of extensively managed farmland where light availability is higher. Reduced fertilizer use on conventional field margins will increase light availability and thus improve habitat conditions for arable plant species.

Wesche, K., Krause, B., Culmsee, H., Leuschner, C., 2012. Fifty years of change in Central European grassland vegetation: large losses in species richness and animalpollinated plants. Biological Conservation, 150: 76-85.

There is growing concern that biodiversity loss in European agricultural landscapes is having negative effects on functional trait diversity. Long-term studies examining vegetation changes from the period before agricultural industrialisation are however rare. Here, we ask how management intensification and increased nutrient input initiated in the 1950/1960s have altered grassland plant community composition, species diversity and functional trait composition using comprehensive data sets from five floodplain regions (plus one protected reference region) in northern Germany. Sites with available historical relevés and vegetation maps (1950/1960s, 1990s) were resampled in 2008 to facilitate the analysis of a period spanning four to five decades.

Plant community composition changed tremendously in all study regions during the 50 year period, which was related to increasing Ellenberg indicator values for nutrient availability. Species richness at the plot-level fell by 30-50\% over the period, and losses in functional diversity were equally large. A non-formal comparison with the results from the protected reference study region indicates that the changes may mostly be attributable to local nutrient input rather than to supra-regional climate change. Our results indicate a consistent trend towards much more species-poor communities dominated by mowtolerant, N-demanding competitive grasses, whereas species with more ruderal strategies, species flowering early in the season and, in particular, insect-pollinated herbs have all decreased. The substantial loss of nectar-producing grassland herbs is likely to have negative effects on the abundance of pollinating insects, with consequences for the grassland animal communities. This highlights the growing need for adequate grassland management schemes with low $\mathrm{N}$ input to preserve high-nature-value grassland. 


\section{Zusammenfassung der Veröffentlichungen}

Die Habilitationsschrift besteht aus 16 Veröffentlichungen, die in der folgenden deutschsprachigen Übersicht zusammengefasst werden.

Literaturhinweise werden an dieser Stelle nur gegeben, wenn es zur Einordnung in den wissenschaftlichen Zusammenhang der Arbeit oder für das methodische Verständnis erforderlich ist. Die Gesamtliste der berücksichtigten Referenzen ist den jeweiligen Originalpublikationen zu entnehmen.

Berg, C.C., Culmsee, H., 2011. Ficus schwarzii redefined and two new species of Ficus (Moraceae) from Sulawesi (Indonesia) described. Blumea, 56: 265-269.

Korrektur der Beschreibung von Ficus schwarzii und Beschreibung zweier neuer Ficus-Arten (Moraceae) aus Sulawesi (Indonesien)

Auf Grundlage von neuen Aufsammlungen von Ficus subg. Sycomorus (Moraceae), die von Culmsee in tropischen Bergregenwäldern Sulawesis (Indonesien) in den Jahren 2006-2007 getätigt wurden, war eine Revision des Subgenus notwendig. Hier werden zwei neue Arten, Ficus sulawesiana und Ficus gorontaloensis, beschrieben und die bisherige Beschreibung von Ficus schwarzii Koord. korrigiert. Ein modifizierter Schlüssel für die auf Sulawesi vorkommenden Arten des Subgenus Sycomorus wird bereitgestellt (vgl. Berg \& Corner, 2005: 328-330).

Brambach, F., Nooteboom, H.P., Culmsee, H., 2013. Magnolia sulawesiana described, and a key to the species of Magnolia (Magnoliaceae) occurring in Sulawesi. Blumea, 58: 271-276.

Beschreibung von Magnolia sulawesiana mit einem Bestimmungsschlüssel der auf Sulawesi vorkommenden Magnolia-Arten (Magnoliaceae)

Die Familie der Magnoliaceae ist in Malesia gründlich untersucht. Aus der Region waren bisher 36 Arten der Gattung Magnolia bekannt, von denen 25 endemisch sind. Hier wird nun eine neue Art, Magnolia sulawesiana, beschrieben, die in den Jahren 2007 und 2011 von Culmsee und Brambach in Bergregenwäldern Sulawesis gesammelt wurde. Bisher sind nur Belege der Art aus der zentralen Gebirgsregion Sulawesis bekannt. Dort kann sie in Primärregenwäldern der montanen Stufe (1600 bzw. 1900 m ü. NN) die Baumkronenschicht (co-)dominieren. Der Bestimmungsschlüssel für Magnolia subsect. Elmerrillia (Section Michelia) wird erweitert (vgl. Nooteboom, 1988; Figlar \& Nooteboom, 2004). Es wird außerdem ein neuer, auf vegetativen Merkmalen basierender Bestimmungsschlüssel für die auf Sulawesi vorkommenden Arten der Gattung Magnolia vorgestellt, mit dem die Feldansprache erleichtert werden soll. 


\section{Culmsee, H., 2008. Dysoxylum quadrangulatum, and notes on Meliaceae in Sulawesi.} Blumea, 53: 602-606.

Dysoxylum quadrangulatum und Bemerkungen zu Meliaceae auf Sulawesi

Die Gattung Aglaia Lour. ist die artenreichste Gattung der Familie der Meliaceae und besitzt einen deutlichen Diversitätsschwerpunkt in Malesia. Die meisten übrigen malesischen Vertreter der Familie gehören den nah verwandten Gattungen Dysoxylum Blume und Chisocheton Blume an. Bisher wurden 21 Aglaia-, neun Dysoxylum- und sieben Chisocheton-Arten für Sulawesi nachgewiesen (davon zwei Endemiten in Chisocheton). Hier wird nun eine neue Art, Dysoxylum quadrangulatum, beschrieben und in den bestehenden Bestimmungsschlüssel eingeordnet (Mabberley et al., 1995: 63-66). Die Art kommt im Unterstand eines ungestörten Bergregenwalds der submontanen Stufe (1050 m ü. NN) im Lore Lindu Nationalpark (Sulawesi, Indonesien) vor. Bisher sind keine weiteren Belege anderer Fundorte bekannt.

Bei umfassenden Bauminventuren in diesem Primärregenwald, bei denen Bäume mit einem Brusthöhendurchmesser $\geq 2 \mathrm{~cm}$ berücksichtigt wurden, waren die Meliaceae mit elf Arten die zweit-artenreichste Familie. Durch den Erstnachweis von Dysoxylum acutangulum Miq. auf Sulawesi konnte die Verbreitungslücke zwischen den beiden im westlichen und östlichen Teil Malesias vorkommenden Unterarten zugunsten des östlich verbreiteten Dysoxylum acutangulum Miq. subsp. foveolatum (Radlk.) Mabb. geschlossen werden.

Culmsee, H., Leuschner, C., 2013. Consistent patterns of elevational change in tree taxonomic and phylogenetic diversity across Malesian mountain forests. Journal of Biogeography, 40: 1997-2010.

Einheitliche Muster in den Veränderungen der taxonomischen und phylogenetischen Diversität von Baumgemeinschaften entlang des Höhengradienten in Bergregenwäldern verschiedener Malesischer Subregionen

Um aufzuklären, welche relative Bedeutung ökologische Prozesse (Spezialisierung für bestimmte Habitate) und biogeographische Prozesse (Artbildung, geographische Ausbreitungsgrenzen) für eine nicht-zufällige räumliche Verteilung von Baumarten in Malesischen Bergregenwäldern besitzen, wurden Veränderungen in der taxonomischen und phylogenetischen Diversität von Baumgemeinschaften entlang des Höhengradienten und in verschiedenen biogeographischen Subregionen analysiert.

Untersuchungsgrundlage waren Baumbestandsinventuren von 12 Primärregenwäldern Malesias (eigene Inventuren aus Sulawesi und vergleichbare Aufnahmen aus Borneo, Java und den Philippinen, d.h. Inventuren mit Angaben zu Individuenzahlen aller Bäume mit Brusthöhendurchmesser $\geq 10 \mathrm{~cm}$ und Bestimmung von $>95 \%$ der Individuen mindestens bis zur Gattung). Die Waldbestände decken einen weiten Höhengradienten von 650-3080 m ü. NN ab (colline, submontane, montane und subalpine Stufen). Die 12 Datensätze wurden zunächst hinsichtlich der verwendeten systematischen Nomenklatur harmonisiert (Analysen auf Genus-Ebene wegen hoher Anzahl von Morphospecies in bisher noch nicht systematisch aufgearbeiteten Gruppen; Abgleich von Synonymen nach van Steenis, 1948-2010 und Verwendung der gültigen Nomenklatur von Stevens, 2001 ff.). Da die Größe der Untersuchungsflächen und die Anzahl der aufgenommenen Individuen stark variierten, wurden die Datensätze standardisiert (alle Analyseergebnisse beruhen auf Mittelwerten von 
je 50 randomisierten Ziehungen von 245 Baumindividuen pro Aufnahmefläche). Für die phylogenetische Diversitätsanalyse wurde eine Phylogenie der 204 vorkommenden Genera erstellt, die auf den evolutionären Ursprungs skaliert wurde (vgl. Supporting Information der Publikation, Appendix S1). Es wurden ausschließlich effektive Diversitätsmaße angewendet. Bei der Berechnung der taxonomische alpha-Diversität kam der Exponent der ShannonEntropie $[\exp (\mathrm{H})$, Chao \& Shen, 2003; Jost, 2006] und als beta-Diversitätsmaß Whittakers effektiver Artenumsatz ( $\beta_{\mathrm{Mt}-1}$, Tuomisto, 2010b) zur Anwendung. Als phylogenetische Diversitätsmaße wurden standardisierte Größen für die Gesellschaftsstruktur (NRI, Net Relatedness Index bzw. NTI, Nearest Taxon Index; Webb et al., 2009) und phylogenetische Distanz ( $\beta_{\mathrm{NTl}}$, inter-sample phylogenetic distance; Webb et al., 2009) verwendet. Diversitätsmuster wurden mit Hilfe von Regressionsanalysen, Ordinations- und Klassifikationsverfahren untersucht.

Der Höhengradient war der Hauptfaktor, der die Muster in der Diversität der untersuchten Baumgemeinschaften bestimmte, während der Einfluss der Subregion überraschend gering ausfiel. Entlang des Höhengradienten waren Muster in der taxonomischen und phylogenetischen Gesellschaftsstruktur (auf Genus-Ebene) in den West- und ZentralMalesischen Untersuchungsräumen also einheitlich ausgebildet. Die großen Abstammungslinien der zeitgenössischen Baum-Gattungen der Bergregenwälder müssen also vor der Ausbildung des Malaiischen Archipels entstanden sein (Sympatrie).

Taxonomische und phylogenetische alpha-Diversität zeigten entlang des Höhengradienten gegensätzliche Tendenzen. Die effektive Anzahl der Gattungen nahm mit aufsteigender Höhe linear ab. Die phylogenetische Struktur von höher gelegenen Bergregenwäldern wies eine Überdispersion (eine höhere Variabiliät als erwartet) auf, was eine konvergente Evolution von Merkmalen anzeigt. Die Zusammensetzung der in den tieferen submontanen und collinen Stufen gelegenen Bergregenwälder zeigte dagegen einen phylogenetischen Klumpungseffekt mit einer beachtlichen Menge an Gattungen, die derselben Familie angehören.

Die hochmontanen Wälder von Borneo und Sulawesi unterschieden sich von den tiefer gelegenen Bergregenwäldern hauptsächlich durch die Dominanz von Koniferen der südlichen Hemisphäre (Podocarpaceae, Phyllocladaceae).

Die Ergebnisse zeigen, dass ökologische, evolutionäre und biogeographische Prozesse (umweltbedingte Filterung, Sympatrie und Ausbreitungsfähigkeit über weite Distanzen) die heutige Zusammensetzung der Waldgesellschaften malesischer Bergregenwälder geprägt haben. Die Wallace-Linie mag eine maßgebliche Barriere hinsichtlich der floristischen Zusammensetzung der Tieflandregenwälder sein. Für die Flora der Bergregenwälder gilt dies jedoch nicht. Die Einzigartigkeit der hochmontanen Regenwälder in Hinsicht auf ihre außerordentliche phylogenetische Diversität und ihre ungewöhnliche Struktur macht eine hohe Priorität dieser Wälder für Naturschutzprogramme unbedingt erforderlich.

Culmsee, H., Leuschner, C., Moser, G., Pitopang, R., 2010. Forest aboveground biomass along an elevational transect in Sulawesi, Indonesia, and the role of Fagaceae in tropical montane rain forests. Journal of Biogeography, 37: 960-974.

Die oberirdische Biomasse von Wäldern entlang eines Höhengradienten auf Sulawesi, Indonesien, und die Rolle der Fagaceae in tropischen Bergregenwäldern 
Es wurde der Frage nachgegangen, wie sich die oberirdische Biomasse der Bäume tropischer Bergregenwälder entlang eines Höhengradienten ändert und wie diese Änderung in Beziehung zur Veränderungen in der floristischen Zusammensetzung, der phylogenetischen Gesellschaftsstruktur und der Biogeographie der dominanten Baumarten steht.

Die Felduntersuchungen fanden im Lore Lindu Nationalpark, Sulawesi, Indonesien, statt. Auf 13 Probeflächen (à 0,24 ha) wurden in vier alten Waldbeständen baumindividuenbasiert floristische und strukturelle Aufnahmen durchgeführt. Die Bestände lagen auf 1050, 1400, 1800 und $2400 \mathrm{~m}$ ü. NN und bildeten somit ein Transekt von der submontanen bis zur hochmontanen Höhenstufe. Die oberirdische Biomasse der Einzelbäume wurde auf Grundlage des Brusthöhendurchmessers, der Baumhöhe und der (art- bzw. gattungsspezifischen) Holzdichte nach der Formel für die humiden Tropen von Chave et al. (2005) berechnet. Phylogenetische Diversität und biogeographische Muster wurden auf Familien-Ebene, gewichtet mit den berechneten Werten der oberirdischen Biomasse, analysiert. Darüber hinaus wurde der generelle Trend von Veränderungen in den oberirdischen Biomassewerten entlang des Höhengradienten analysiert, indem das in dieser Studie untersuchte Transekt aus Sulawesi mit sieben weiteren Transekten aus Südost-Asien und den Neotropen verglichen wurde.

Die untersuchten Bestände des Transekts auf Sulawesi zeigten eine mehr oder weniger gleichbleibende oberirdische Biomasse von der submontanen bis zur mittleren montanen Stufe (309-301 Mg ha-1); erst in der hochmontanen Stufe stieg die oberirdische Biomasse leicht auf $323 \mathrm{Mg} \mathrm{ha}^{-1}$ an. Während mittlere Stamm- und Kronenhöhe mit aufsteigender Höhenstufe abnahmen, nahm die Holzdichte zu. Baumarten, die den Magnoliids zugehören (vgl. Angiosperm Phylogeny Group, Stevens, $2001 \mathrm{ff}$.), bildeten den überwiegenden Teil der oberirdischen Biomasse in der submontanen Stufe, während Eurosids I (inkl. Fagaceae) auf allen Höhenstufen ganz erhebliche oberirdische Biomasse bildeten.

Die phylogenetische Diversität (Rao's quadratic entropy, $\mathrm{PD}_{\mathrm{Q}}$ ) war in der oberen montanen Stufe am höchsten; dort co-dominierten Baumfarne, Podocarpaceae, Trimeniaceae und Asterids/Euasterids II. Am niedrigsten war $\mathrm{PD}_{\mathrm{Q}}$ in den unteren und mittleren montanen Stufen; dort bildeten die Fagaceae $>50 \%$ der oberirdischen Biomasse.

Die Analyse der biogeographischen Muster zeigte eine Progression von dominanten tropischen Familien in der submontanen Stufe, zu tropischen Fagaceae (Castanopsis, Lithocarpus) in der unteren und mittleren montanen Stufe, und zu Koniferen und australasischen Endemiten in der hochmontanen Stufe.

Der Vergleich von unterschiedlichen Transektstudien verschiedener Kontinente zeigte eine Abnahme der oberirdischen Biomasse mit steigender Höhenstufe, wenn nur ein geringer Anteil oder keine Fagaceae vertreten waren, aber eine relativ hohe Biomasse in den Bergregenwäldern, in denen Vertreter der Fagaceae in mäßiger bis hoher Menge vorhanden waren.

Es wird geschlussfolgert, dass die Höhe der oberirdischen Biomasse in tropischen Bergregenwäldern zum einen durch Unterschiede in der Waldstruktur, zum anderen in Veränderungen in der Baumartenzusammensetzung bestimmt wird. Obwohl in dem untersuchten Höhentransekt auf Sulawesi große Veränderungen in der Waldstruktur und in der Artenzusammensetzung festgestellt werden konnten, glichen sich die beiden Faktoren 
soweit aus, dass netto keine Veränderung in der oberirdischen Biomasse ersichtlich war. Südostasiatische Bergregenwälder, die von Fagaceae dominiert werden, bilden wichtige Kohlenstoffspeicher. Die Bedeutung der Biogeographie und von funktionellen Merkmalen (Holzdichte) der bestandsbildenden Baumarten sollten stärker von REDD-Initiativen (Reducing the Emissions from Deforestation and Forest Degradation) und bei der Auswahl von Baumarten, die für Aufforstungsmaßnahmen als Kohlenstoffausgleich verwendet werden, berücksichtigt werden.

\section{Culmsee, H., Pitopang, R., 2009. Tree diversity in sub-montane and lower montane primary rain forests in Central Sulawesi. Blumea, 54: 119-123.}

Die Baumdiversität submontaner und unterer montaner Bergregenwälder in Zentral-Sulawesi

Die Baumdiversität submontaner und unterer montaner primärer Bergregenwälder wurde in zwei Waldbeständen im Lore Lindu Nationalpark, Zentral-Sulawesi, untersucht. Diese Studie war eine der ersten, in der für Sulawesi Diversitätsmuster von Bergregenwäldern verschiedener Höhenstufen miteinander verglichen wurden.

Inventuren in einem submontanen Wald (1050 m ü. NN) umfassten 1,44 ha (6 Probeflächen à $0,24 \mathrm{~h}$ ). In einem unteren montanen Wald (1400 $\mathrm{m}$ ü. NN) fanden Inventuren auf einer geringeren Fläche von 0,72 ha statt (3 Probeflächen à 0,24 ha). Es wurden alle Baumindividuen mit einem Brusthöhendurchmesser $(B H D) \geq 10 \mathrm{~cm}$ aufgenommen. Auf je einem Viertel der Fläche wurden zusätzlich alle Bäume mit BHD = 2,0-9,9 cm verzeichnet. Die Artenzahlen wurden mit Hilfe einer Rarefaction-Analyse (Gotelli \& Colwell, 2001) vergleichbar gemacht. Anhand des Family Importance Values (FIV, Mori et al., 1983) wurde der Beitrag jeder Familie zum Gesamtbestand berechnet.

Insgesamt wurden 166 Baumarten bestimmt. Davon waren die Hälfte Neunachweise entweder für die Insel Sulawesi (19\%) oder für die Provinz Zentral-Sulawesi (31\%) (vgl. Keßler et al., 2002). Die (rarifizierte) Artenzahl war in der unteren montanen Stufe kleiner als in der submontanen Stufe. Im submontanen Wald waren die wichtigsten Familien (FIV) die Lauraceae, Fagaceae, Sapotaceae, Moraceae und Euphorbiaceae. Im unteren montanen Wald erreichten die Fagaceae den höchsten FIV-Wert (FIV = 71,9); es folgten in einigem Abstand Myrtaceae, Elaeocarpaceae und Lauraceae. Für jeden der beiden Wälder konnte eine Gruppe von Familien identifiziert werden, die in dem anderen jeweils nicht oder nur in geringem Maße von Bedeutung waren.

Aus dem Vergleich der eigenen Ergebnisse zur Basalfläche, Artenzahl und FIV mit anderen publizierten aufnahmeflächenbasierten Bauminventuren von submontanen und unteren montanen Primärregenwäldern Malesias (Borneo, Sulawesi und Papua-Neuguinea) konnte gefolgert werden: (1) Die Basalfläche der beiden untersuchten Wälder (35,4 bzw. 37,1 $\mathrm{m}^{2}$ ha$\left.{ }^{1}\right)$ war vergleichbar mit der von Wäldern auf Borneo und Papua-Neuguinea, konnte dagegen die früher aus Sulawesi beschriebene ungewöhnlich hohe Basalfläche von Wäldern nicht unterstützen; (2) die Artenzahl war vergleichbar mit der von Wäldern auf Borneo und anderen Wäldern auf Sulawesi, aber geringer als die von Wäldern Papua-Neuguineas; (3) die beobachtete abnehmende Baumartenzahl mit der Höhenstufe korrespondierte zu anderen Studien auf Borneo; (4) die Lauraceae waren eine wichtige Baumfamilie der submontanen Stufe; die Baumartenzusammensetzung der Wälder auf Sulawesi war der von 
Wäldern auf Papua-Neuguinea sehr ähnlich; (5) untere montane Wälder hatten die Fagaceae und Myrtaceae als wichtige Familien gemein.

Culmsee, H., Pitopang, R., Mangopo, H., Sabir, S., 2011. Tree diversity and phytogeographical patterns of tropical high mountain rain forests in Central Sulawesi, Indonesia. Biodiversity and Conservation, 20: 1103-1123.

Baumdiversität und phytogeographische Muster tropischer Hochgebirgswälder ZentralSulawesis, Indonesien

Die Baumartenzusammensetzung und die Bedeutung der vorkommenden Baumfamilien von tropischen Hochgebirgswäldern im Lore Lindu Nationalpark, Sulawesi, Indonesien, wurde auf Grundlage von Bauminventuren (vier Probeflächen à 0,24 ha) in der mittleren montanen und hochmontanen Höhenstufe (1800 und $2400 \mathrm{~m}$ ü. NN) beschrieben. Um allgemeingültige Muster und regionale Besonderheiten dieser Wälder im südostasiatischen und südwestpazifischen Kontext zu identifizieren, wurde die Biogeographie der Baumarten anhand von Verbreitungsmustern in Malesia analysiert. Für die biogeographische Analyse wurde die Verbreitung der untersuchten Baumarten in den neun Hauptregionen Malesias (vgl. phytogeographisches Konzept nach Brummitt, 2001) anhand umfangreicher Revisionen der Flora Malesiana und der im Nationalherbarium der Niederlande (Universität Leiden) vorhandenen Herbarbelege der Baumarten recherchiert.

Von den insgesamt 87 Baumarten wurden nur 18 Arten in beiden Höhenstufen vorgefunden. Die Entdeckung von neuen Arten und neuen Verbreitungsnachweisen (28\% der Baumarten in diesem Datensatz) zeigte das hohe Defizit in der taxonomischen Bearbeitung und der Kenntnis der Verbreitung der Arten auf Sulawesi auf. Die Endemismusrate unter den bearbeiteten Baumarten betrug $20 \%$ (Vorkommen begrenzt auf Sulawesi). Die FagaceaeMyrtaceae-Wälder der mittleren montanen Stufe wiesen typische Merkmale der montanen Wälder Malesias auf; Lithocarpus sp. (Fagaceae) war die absolut dominierende Gattung (4 Arten, die etwa die Hälfte der Basalfläche des Bestandes abdeckten) und die Myrtaceae waren die artenreichste Familie (8 Arten). Die hochmontanen Koniferen-Myrtaceae-Wälder enthielten zahlreiche hochmontane Baumtaxa und wiesen eine hohe Affinität zu Wäldern von Neu-Guinea auf. Die Gebirgsflora von Sulawesi umfasste sowohl ost- als auch westmalesische Elemente, wobei Sulawesi die meisten Baumarten mit den beiden nächstgelegenen Inselgruppen, Borneo und Molukken, gemeinsam hatte. Dies spiegelt die komplexe Paläogeographie der Insel Sulawesi wider. Eine separate Analyse der mittleren montanen und hochmontanen Wälder zeigte, dass der mittlere montane Wald eine größere biogeographische Affinität zu Borneo/dem west-malesischen Raum besaß. Der hochmontane Wald besaß dagegen eine Vielzahl von typischen Elementen von Papuasia/dem ost-malesischen Raum und den Philippinen, was vermutlich auf historische Landverbindungen und Gebirgsbildungsprozesse zurückzuführen ist.

Culmsee, H., Schmidt, M., Schmiedel, I., Schacherer, A., Meyer, P., Leuschner, C., 2014. Predicting the distribution of forest habitat types using indicator species to facilitate systematic conservation planning. Ecological Indicators, 37: 131-144.

Die Prognose der Verbreitung von Waldhabitaten anhand von Indikatorarten zur Erleichterung einer systematischen Naturschutzplanung 
Kürzlich vorgelegte Evaluationsberichte haben ein bedeutendes Defizit im bestehenden Ansatz zur Identifizierung von Natura 2000-Schutzgebieten in ganz Europa festgestellt. Ein systematisch ausgerichteter Ansatz zur Planung des Schutzgebietsnetzes, bei dem strategische Weiterentwicklungsmöglichkeiten sowie räumliche Verteilungsmuster und das Areal von Arten und Habitaten berücksichtigt werden, ist unbedingt notwendig, um Entscheidungsprozesse zur potentiellen Ausweitung, der Umsetzung und/oder der Erhaltung von Schutzgebieten zu unterstützen.

In dieser Studie wurde eine Methode entwickelt, mit der in einer großen Modellregion, dem Land Niedersachsen, Waldlebensräume der gemäßigten Zone, die einen hohen Naturschutzwert besitzen, anhand von Verbreitungskarten von Indikatorarten systematisch lokalisiert und bewertet werden können. Indikatorarten der Waldgesellschaften wurden aufgrund ihrer Waldbindung (Waldartenliste, Schmidt et al., 2011) und ihrer Gesellschaftstreue (basierend auf einer Übersicht von 5.338 Vegetationsaufnahmen) ermittelt. Bekannte Vorkommen von Beständen dieser Waldgesellschaften (Habitate) wurden aus Biotopkartierungen und Fundortangaben in der Literatur abgeleitet. Basierend auf einem Raster von 1.739 räumlichen Einheiten von ca. $30 \mathrm{~km}^{2}$ (Rasterzellen) wurde der Zusammenhang von Habitatvorkommen und Indikatorartenverteilungen mit logistischen Regressionen analysiert.

Die Vorhersagekraft der aus räumlichen Indikatorartenverteilungen abgeleiteten Verbreitungsmodelle der Waldlebensraumtypen stieg mit der Anzahl der Indikatorarten an. Eine enge Korrelation von Indikatorartenverteilung und Habitatvorkommen konnte jedoch nur nachgewiesen werden, wenn ausschließlich Indikatorarten verwendet wurden, die eine enge Waldbindung aufzeigten. Feldüberprüfungen von Rasterzellen, in denen die Modelle eine hohe Vorkommenswahrscheinlichkeit von Waldgesellschaften vorhersagten, führten zu zahlreichen Neunachweisen von Waldbeständen wertvoller Waldgesellschaften des Hügellandes. Durch die Einbeziehung dieser Neufunde konnten wiederum die Verbreitungsmodelle erheblich verbessert werden.

Es wurde geschlussfolgert, dass die Verbreitung von für den Naturschutz wertvollen Waldhabitaten aus Artenverbreitungskarten, die auf relativ großräumigen Rasterdatensätzen beruhen, abgeleitet werden kann, wenn ausschließlich Indikatorarten mit hoher Waldbindung und einer hohen Bindung an eine einzige Gesellschaft für die Verbreitungsmodelle ausgewählt werden. Der hier vorgestellte methodische Ansatz kann eine Nachbearbeitung des bestehenden Natura 2000-Waldschutzgebietsnetzes erleichtern und bietet die Grundlage für ein Monitoring zur Erfolgskontrolle von Maßnahmen des Waldnaturschutzes.

\section{Gradstein, S., Culmsee, H., 2010. Bryophyte diversity on tree trunks in montane forests of Central Sulawesi, Indonesia. Tropical Bryology, 31: 95-105.}

\section{Moosdiversität an Baumstämmen in Bergregenwäldern Zentral-Sulawesis, Indonesien}

Frühere Untersuchungen haben gezeigt, dass submontane Wälder Sulawesis eine äußerst reiche Moosflora beherbergen, wobei schon mehr als 150 Arten an nur acht Bäumen, die das Kronendach erreichen, nachgewiesen werden konnten. Hier wurde nun die Beziehung von Moosgesellschaften an der Stammbasis von Bäumen mit der Höhenstufe und mit Merkmalen der Bäume (Stammdurchmesser, Rauhigkeit der Rinde) in montanen Wäldern Sulawesis untersucht. 
Die Untersuchungen zeigten, dass submontane, untere montane und hochmontane Wälder in Sulawesi durch sehr unterschiedliche Moos-Taxa charakterisiert werden. In den tieferen Höhenlagen wurden hauptsächlich Calymperaceae, Fissidentaceae, Hypopterygiaceae, Lejeuneaceae, Leucobryaceae, Lophocoleaceae, Meteoriaceae, Neckeraceae, Porellaceae, Pterobryaceae, Radulaceae und Thuidiaceae gefunden. In höheren Lagen herrschten dagegen Herbertaceae, Lepidoziaceae, Mastigophoraceae, Scapaniaceae, Schistochilaceae und Trichocoleaceae vor. Lejeuneaceae waren in submontanen und unteren montanen Wäldern, Lepidoziaceae im hochmontanen Wald die wichtigsten Familien in Hinsicht auf ihre Artenzahl. Plagiochilaceae waren im unteren montanen Wald verbreitet.

Die Artenzahl der Lebermoose stieg mit der Höhenstufe des Gebirges an, während die der Laubmoose sank. Ähnliche Trends konnten auch in anderen Gebieten der Tropen aufgezeigt werden. Die Ähnlichkeit der die Basis von Baumstämmen besiedelnden tropischen Moosgemeinschaften sank mit der räumlichen Distanz. Im Vergleich von Borneo und Sulawesi beträgt sie nur noch $25 \%$ und ist im inter-kontinentalen Vergleich nicht mehr nachweisbar. Einige Arten bevorzugten deutlich eine raue Baumrinde, aber es gab keine Arten mit einer Präferenz für eine glatte Rinde. Bäume mit rauer Rinde beherbergten generell mehr Moosarten als solche mit glatter Rinde. Der Stammdurchmesser korrelierte mit der Verteilung einiger Moosarten, aber nicht mit der Zusammensetzung oder der Artenzahl der Moosgesellschaften. Die hier vorgestellten Daten sind die ersten, die einen statistisch überprüften Zusammenhang der Rauhigkeit der Baumrinde bzw. des Stammdurchmessers mit der Moosdiversität in baumartenreichen tropischen Wäldern belegen.

Hertel, D., Moser, G., Culmsee, H., Erasmi, S., Horna, V., Schuldt, B., Leuschner, C., 2009. Below- and above-ground biomass and net primary production in a paleotropical natural forest (Sulawesi, Indonesia) as compared to neotropical forests. Forest Ecology and Management, 258: 1904-1912.

Unter- und oberirdische Biomasse und Netto-Primärproduktion in einem paläotropischen Naturwald (Sulawesi, Indonesien) im Vergleich zu neotropischen Wäldern

Daten zur Biomasse und Produktivität tropischer Wälder Südost-Asiens sind selten. Dies erschwert die Bewertung der Rolle, die diese Waldökosysteme für den globalen Kohlenstoffkreislauf besitzen, und der Auswirkungen, die die zunehmende Abholzung in der Region hat. Genauere Informationen werden insbesondere über das Ausmaß und die Dynamik von Wurzelsystemen benötigt.

Oberirdische Biomasse, Verteilung von Feinwurzeln $(<2 \mathrm{~mm}$ Durchmesser $)$ und Grobwurzeln ( $>2 \mathrm{~mm}$ Durchmesser) sowie geschätzte ober- und unterirdische NettoPrimärproduktion wurden in sechs submontanen Naturwaldbeständen (ca. $1000 \mathrm{~m}$ ü. NN) in Sulawesi (Indonesien) bestimmt. Die Ergebnisse wurden mit Literaturdaten anderer submontaner Wälder der Paläo- und Neotropen verglichen.

Die mittlere Gesamtbiomasse der Bestände auf Sulawesi betrug $303 \mathrm{Mg} \mathrm{ha}^{-1}$ (oder $128 \mathrm{Mg} \mathrm{C}$ $\mathrm{ha}^{-1}$ ). Den größten Biomasseanteil hatte das oberirdische Kompartiment (286 Mg ha ${ }^{-1}$ ). Grobund Feinwurzeln bildeten eine Biomasse von 11,2 und $5,6 \mathrm{Mg} \mathrm{ha}^{-1}$ (bis $300 \mathrm{~cm}$ Bodenprofiltiefe). Dies führte zu einem bemerkenswert hohen Spross-Wurzelverhältnis von ca. 17. Die Feinwurzeldichte im Bodenprofil wies eine exponentielle Abnahme mit der Bodentiefe auf; dies stand in enger Beziehung zu basischen Kationenkonzentrationen, $\mathrm{pH}$ - 
Wert des Bodens und besonders zum Gesamt-Phosphor und Gesamt-Stickstoff. Die oberirdische Biomasse der untersuchten Bestände war wesentlich höher als der durchschnittliche Wert für neotropische Wälder, aber niedriger als in anderen submontanen Wäldern der Paläotropen, insbesondere den Dipterocarpaceae-Wäldern Malesias.

Die gesamte ober- und unterirdische Netto-Primärproduktion wurde auf $15,2 \mathrm{Mg} \mathrm{ha}^{-1} \mathrm{yr}^{-1}$ (oder 6,7 Mg C ha-1 $\mathrm{yr}^{-1}$ ) geschätzt. Davon waren $14 \%$ unterirdische und $86 \%$ oberirdische Netto-Primärproduktion. Die Blattproduktion war größer als die Stammproduktion. Im globalen Mittel der submontanen Tropenwälder war die geschätzte oberirdische Produktion hoch, sie war aber wesentlich niedriger als in Dipterocarpaceae-Wäldern Südost-Asiens.

Es wurde geschlussfolgert, dass die auf Sulawesi untersuchten submontanen Wälder dem generellen Trend einer höheren Biomasse und Produktivität von paläotropischen im Vergleich zu neotropischen Wäldern folgen. Biomassevorräte und Produktivität sind jedoch in den Wäldern Sulawesis, die besonders reich an Fagaceae sind, niedriger als in den Dipterocarpaceae-Wäldern West-Malesias.

\section{Krause, B., Culmsee, H., 2013. The significance of habitat continuity and current management on the compositional and functional diversity of grasslands in the uplands of Lower Saxony, Germany. Flora, 208: 299-311.}

Die Bedeutung von Habitatkontinuität und aktueller Nutzung für die kompositorische und funktionale Diversität von Grasländern im Niedersächsischen Hügelland

Es herrscht eine zunehmende Besorgnis darüber, dass die Intensivierung der Landnutzung in Mitteleuropa nicht nur einen negativen Einfluss auf halbnatürliches Grasland hat, sondern auch zu einem generellen Biodiversitätsverlust aller ehemals extensiv genutzten nährstoffarmen und mäßig nährstoffreichen Grünlandtypen führt.

Seit den 1950er Jahren ist im mitteleuropäischen Hügelland die als Grünland genutzte landwirtschaftliche Fläche infolge des Landnutzungswandels gestiegen. In dieser Studie wurde eine solche Landschaft in Niedersachsen als Modellregion genutzt. Dabei wurden die Umweltfaktoren, die die Diversität des Grünlandes hinsichtlich Artenzusammensetzung, Artenzahl und Bestäubungsmerkmalen beeinflussen, untersucht. In einem 2500 ha großen Untersuchungsgebiet wurde die Vegetation auf 189 Probeflächen, die zufällig auf 394 ha Grünlandfläche verteilt waren, aufgenommen. Pflanzengesellschaften wurden mit der TWINSPAN-Methode (Hill \& Šmilauer, 2005) klassifiziert. Der Einfluss von Umweltfaktoren (Boden, Topographie, aktuelle Nutzung und Habitatskontinuität) wurde mit Kanonischen Korrespondenzanalysen und Regressionsanalysen ausgewertet, wobei der Einfluss der räumlichen Autokorrelation anhand einer Hauptkoordinatenanalyse von Nachbarschaftsmatrizen reduziert wurde (PCNM-Analyse nach Borcard et al., 1992; Borcard \& Legendre, 2002).

Es wurden sechs artenarme (< 15 Gefäßpflanzenarten) bis sehr artenreiche ( $>27$ Arten) Grünlandtypen mittlerer bis trockener Standorte unterschieden. Diese umfassten Grünlandeinsaaten, Grünlandgesellschaften der Verbände Cynosurion und Arrhenatherion und halbnatürliches Grasland (Magerrasen). Die Artenzusammensetzung der Grünlandgesellschaften wurde am besten durch Bodeneigenschaften, Artenzahl und Bestäubungsmerkmale der Gesellschaften dagegen durch den kombinierten Effekt der aktuellen Nutzung und der Habitatkontinuität erklärt. In den 1950/60er Jahren stieg die 
Grünlandfläche im Untersuchungsgebiet sprunghaft auf mehr als das Doppelte der früheren Ausdehnung an. Im Jahr 2007 bedeckte Grünland 16 \% der Landschaft. Natura 2000Lebensraumtypen waren nur in $1 \%$ der untersuchten Grünlandflächen vorhanden und Wirtschaftsgrünland mit hohem ökologischem Wert umfasste weitere $5 \%$ der Gründlandfläche.

Während die Zahl der windbestäubten Pflanzenarten in allen Grünlandtypen gleich hoch war, war eine parallele Abnahme von insektenbestäubten Pflanzenarten und mittlerer Pflanzenartenzahl in den Grünlandgesellschaften entlang eines Gradienten zunehmender Landnutzungsintensität (Mahdfrequenz, Nährstoffversorgung) festzustellen. Die insektenbestäubten Arten, die im Intensivgrünland vorkamen, hatten zusätzlich die Fähigkeit zur Selbstbestäubung.

Artenreiches Grasland (Magerrasen und wenig melioriertes, artenreiches Grünland des Arrhenatherion) kam ausschließlich auf historisch alten Gründlandstandorten vor ( $>100$ Jahre Habitatkontinuität), das aktuell als traditionelle Schafweide genutzt wurde (Maßnahmen des Vertragsnaturschutzes). Mittelartenreiches Grünland des Arrhenatherion war hauptsächlich auf weniger produktiven früheren Ackerstandorten etabliert $(<30$ Jahre Habitatkontinuität).

Es wurde geschlussfolgert, dass sich Naturschutzmaßnahmen auf noch vorhandene artenreiche Gründlandtypen konzentrieren und traditionelle Landnutzungsformen zur Anwendung gebracht werden sollten. Zusätzlich sollte mit Renaturierungsmaßnahmen neues Grünland auf wenig produktiven Standorten in der unmittelbaren Nähe von artenreichen Grünlandstandorten etabliert werden, wodurch der Sameneintrag erleichtert wird und gleichzeitig Stickstoffeinträge abgepuffert werden können. Diese Maßnahmen würden die Interaktionen zwischen ökologisch wertvollem Grasland in Schutzgebieten und landwirtschaftlicher Grünlandfläche und damit die ökologische Qualität des Gründlands auf Landschaftsebene verbessern.

Krause, B., Culmsee, H., Wesche, K., Bergmeier, E., Leuschner, C., 2011. Habitat loss of floodplain meadows in north Germany since the 1950s. Biodiversity and Conservation, 20: 2347-2364.

Habitatverluste des Auengrünlands in Norddeutschland seit den 1950er Jahren

Auengrünland ist in Mitteleuropa besonders stark durch Landnutzungswandel und Intensivierung der Landwirtschaft gefährdet. In dieser Studie werden qualitative und quantitative Veränderungen in der Vegetation des Feuchtgrünlands und des artenreichen Frischgrünlands in Auengebieten Norddeutschlands seit den 1950er Jahren untersucht. Dabei werden die räumliche Ausdehnung, die Fragmentierung und die Ersetzung durch andere Landnutzungstypen betrachtet.

Historische, hochauflösende Vegetationskarten wurden mit aktuellen Vegetationskartierungen in sieben Untersuchungsgebieten (Auenlandschaften, davon sechs Normallandschaften, ein Schutzgebiet) des Nordwest- und Nordostdeutschen Tieflands verglichen (geostatistische Analysen mit FRAGSTATS 3.0, McGarigal et al., 2002).

Die Auengebiete in der Normallandschaft wiesen alarmierend hohe Verluste $(>80 \%$ der ursprünglichen Fläche) des Feuchtgrünlands und des artenreichen Frischgrünlands in den 
letzten 50 Jahren auf. Feuchtgrünland war durch artenarmes Intensivgrünland (26-60\% der früheren Fläche), Ackerland (0-47\%) oder Brachen (2-33\%) ersetzt worden. Artenreiches Frischgrünland war in Ackerland (42-72\%) oder artenarmes Intensivgrünland (14-72 \%) überführt worden. Die effektive Maschenweite und die Größe der einzelnen Flächen (PatchGröße) des Feuchtgrünlands nahmen ab, was eine zunehmende Fragmentierung des feuchten Auengrünlands anzeigte. Solch einheitliche Veränderungen in der Landschaftsstruktur waren für das Frischgrünland weniger deutlich nachzuweisen. In der untersuchten geschützten Auenlandschaft hatten dagegen nur geringe Veränderungen stattgefunden. Dies deutet darauf hin, dass die Habitatverluste des Auengrünlands auf lokale Einflusse wie Düngung und Entwässerung zurückzuführen sind, nicht jedoch auf generelle Trends wie Luftstickstoffeinträge oder den Klimawandel.

Trotz der verschiedenen politischen systeme und den damit einhergehenden unterschiedlichen agrarökonomischen Rahmenbedingungen in West- und Ostdeutschland bis zur Wende 1989 wiesen alle Auengebiete der Normallandschaft vergleichbare Trends im Verlust und der Fragmentierung des Auengrünlands auf. Dies dürfte die natürliche Dynamik dieser Ökosysteme und auch den Genfluss zwischen den Populationen von Pflanzenarten des Feuchtgrünlands in verschiedenen Auengebieten erheblich negativ beeinflusst haben. Naturschutzmaßnahmen für die Erhaltung und Wiederherstellung des Auengrünlands Norddeutschlands sollten daher hohe Priorität besitzen.

Leuschner, C., Moser, G., Hertel, D., Erasmi, S., Leitner, D., Culmsee, H., Schuldt, B., Schwendenmann, L., 2013. Conversion of tropical moist forest into cacao agroforest: Consequences for carbon pools and annual C sequestration. Agroforestry Systems, 87: 1173-1187.

Umwandlung von tropischem Regenwald in Kakao-Agroforst: Folgen für Kohlenstoffvorräte und jährliche Kohlenstoffbindung

Tropenwälder speichern einen großen Teil des terrestrischen Kohlenstoffs und spielen eine Schlüsselrolle im globalen Kohlenstoffkreislauf. In einigen Gebieten Südost-Asiens trägt die Umwandlung von tropischem Regenwald in Kakao-Agroforst wesentlich zur Abholzung von Regenwäldern bei. Dies führt zur Kohlenstofffreisetzung aus Biomasse und Boden in die Atmosphäre. In der vorliegenden Fallstudie aus Sulawesi, Indonesien, wird ein Naturwald mit in der Nähe gelegenen, unter Schattenbäumen gepflanzten Agro-Forstsystemen verglichen. Dabei werden alle wesentlichen oberirdischen und unterirdischen Kohlenstoffspeicher (Biomasse; jeweils $n=6$ Flächen) und die Netto-Primärproduktion (jeweils $n=3$ Flächen) untersucht.

Die Gesamt-Biomasse (oberirdisch und unterirdisch bis $250 \mathrm{~cm}$ Bodentiefe [Feinwurzeln, Grobwurzeln inkl. Wurzelstock]) des Naturwaldes (c. $150 \mathrm{Mg} \mathrm{C} \mathrm{ha}^{-1}$ ) war achtmal so hoch wie im Agroforst (19 Mg C ha ${ }^{-1}$ ). Die Netto-Primärproduktion (NPP, oberirdisch und unterirdisch) war im Naturwald größer als im Agroforst (c. 29 vs. 20 Mg Trockengewicht ha-1 $\mathrm{y}^{-1}$ ), während der Holzzuwachs im Naturwald doppelt so hoch war (ca. 6 vs. $3 \mathrm{Mg}$ Trockengewicht ha $\mathrm{ha}^{-1} \mathrm{y}^{-1}$ ). Die Bodenkohlenstoffvorräte betrugen im Naturwald 134 und im Agroforst $78 \mathrm{Mg} \mathrm{C}^{-1}$. Die Umwandlung von Regenwald in Kakao-Agroforst verringert den Kohlenstoffvorrat um etwa $130 \mathrm{Mg} \mathrm{C} \mathrm{ha}{ }^{-1}$. Weitere $50 \mathrm{Mg} \mathrm{C}^{-1}$ können aus dem Boden freigesetzt werden. Darüber hinaus verringert sich dadurch, dass Naturwald durch Kakao- 
Agroforst ersetzt wird, die jährliche Kohlenstoffbindung wegen wesentlich geringeren Stammzuwachsraten um 70-80\%.

Schmidt, M., Mölder, A., Schönfelder, E., Engel, F., Schmiedel, I., Culmsee, H., 2014. Determining ancient woodland indicator species for practical use: A new approach developed in northwest Germany. Forest Ecology and Management, 330: 228-239.

Die Bestimmung von Indikatorarten historisch alter Waldstandorte für die praktische Anwendung: Ein neuer, in Nordwest-Deutschland entwickelter Ansatz

Historisch alte Waldstandorte, die seit mehreren hundert Jahren kontinuierlich als Waldfläche bestanden haben, unterscheiden sich deutlich von jüngeren Aufforstungen. Anhand des Vorkommens bestimmter assoziierter Gefäßpflanzenarten, die als ,Indikatorarten historisch alter Waldstandorte' bezeichnet werden, kann man die Kontinuität der Waldbedeckung erkennen. Die Lebensräume historisch alter Wälder beherbergen eine typische und reiche Waldbiodiversität und können oft als ,Biodiversitätshotspots' bezeichnet werden. Um solche für den Naturschutz wertvollen Lebensräume identifizieren zu können, ist es notwendig, Listen von Indikatorarten historisch alter Waldstandorte mit überregionaler Gültigkeit zusammenzustellen.

In dieser Studie führen wir einen neuen methodischen Ansatz ein, der die Erstellung solcher Listen auf Grundlage von bereits vorhandenen Datensätzen aus Pflanzenartenerfassungsprogrammen, Archivdaten und Landnutzungsdaten ermöglicht. Für die Modellregion Nordwest-Deutschlands wurde eine ökologisch interpretierbare Liste von 67 Indikatorarten historisch alter Waldstandorte erarbeitet. Diese Indikatorarten historisch alter Waldstandorte stellen dabei eine Teilmenge einer größeren Gruppe von Arten historisch alter Wälder dar.

Die großräumig gültige Indikatorartenliste kann in Zukunft als nützliches Werkzeug für den Waldnaturschutz dienen. Mögliche Anwendungen sind: (a) die Identifizierung von historisch alten Wäldern in Gebieten, in denen keine historischen Karten vorhanden sind, (b) die Identifizierung von Biodiversitätshotspots von Indikatorarten historisch alter Waldstandorte und (c) die Lokalisierung von alten, halbnatürlichen Wäldern.

Schließlich stellen wir heraus, wie wichtig effektive Naturschutzmaßnahmen für die Erhaltung und Förderung der typischen Pflanzenartenvielfalt historisch alter, halbnatürlicher Wälder sind. Das Naturschutzmanagement sollte darauf abzielen, insbesondere die letzen alten Laubwälder zu erhalten und die Umwandlung von alten Wäldern in Nadel- oder Laubmischwälder zu verhindern.

Außerdem sollten solche Naturschutzmaßnahmen ergriffen werden, durch die Verbindungen zwischen neunen und alten Waldbeständen über Habitatkorridore hergestellt werden. Dabei sollte besonders in alten Laubwäldern mit einer hohen Artenvielfalt nur eine extensive Bewirtschaftung stattfinden, um Bodenstörungen zu verhindern und damit die Biodiversität zu erhalten. 
Seifert, C., Leuschner, C., Meyer, S., Culmsee, H., 2014. Inter-relationships between crop type, management intensity and light transmissivity in annual crop systems and their effect on farmland plant diversity. Agriculture, Ecosystems and Environment, 195: 173-182.

Wechselwirkungen von Fruchtart, Bewirtschaftungsintensität und Lichtgenuss am Boden von einjährigen Kulturen und deren Effekte auf die Pflanzenvielfalt auf Äckern

Der kürzlich erfolgte starke Anstieg in der Nutzung landwirtschaftlicher Flächen für den Energiepflanzenanbau hat in Mittel- und West-Europa zu einer verstärkten Nachfrage nach Ackerflächen und damit $\mathrm{zu}$ einem schnellen Landnutzungswandel in vielen Kulturlandschaften geführt. Anbaukulturen zur Gewinnung von Bioenergie der ersten Generation werden nun auf mehr als 15\% der Ackerfläche Deutschlands kultiviert. Die Folgen dieses Wandels in der Fruchtfolge für die Agrarbiodiversität sind jedoch weitestgehend unbekannt. Bedenken wurden vorgebracht, dass durch diese Entwicklung der Biodiversitätverlust durch die hohe Deckung der Kulturpflanzen und des damit verbundenen geringeren Lichtgenusses am Boden von Energiepflanzenkulturen beschleunigt werden könnte, da sich damit die Wachstumsbedingungen für die ohnehin schon zurückgehenden Ackerwildkräuter noch verschlechterten.

Wir untersuchten die Bestandesdurchlässigkeit für photosynthetisch wirksames Licht (TPAR) von konventionell bewirtschafteten Mais- und Rapsfeldern (Energiepflanzenanbau) und von Wintergetreidefeldern (Nahrungs- und Futtermittelproduktion) und verglichen diese mit der in Getreidefeldern, die nach den Vorgaben von Agrarumweltmaßnahmen bewirtschaftet wurden. Zweitens analysierten wir die Beziehung zwischen Beleuchtungsstärke am Boden und Ackerwildkraut-Diversität, wobei der Einfluss der Bewirtschaftungsweise und von geographisch bedingten Unterschieden berücksichtigt wurden.

Die Beleuchtungsstärke am Boden von Maisbeständen war am geringsten (6\% TPAR), gefolgt von Wintergetreide- und Rapsbeständen (10-13\% TPAR). Feldränder waren heller als das Feldinnere ( $17 \%$ vs.10\% TPAR). Der höchste Lichtgenuss wurde am Boden von Feldern, die nach den Vorgaben von Agrarumweltmaßnahmen bewirtschaftet wurden, gemessen (57\% TPAR); hier wiesen auch die Ackerwildkraut-Gemeinschaften eine größere Diversität auf. Durch die Beleuchtungsstärke am Boden konnte auch ein signifikanter Anteil der Streuung in der Ackerwildkraut-Artenzahl auf konventionell bewirtschafteten Feldrändern erklärt werden $\left(r^{2}=8 \%\right)$. Auswirkungen der Beleuchtungsstärke auf die Zusammensetzung der Ackerwildkraut-Gemeinschaften konnte jedoch nur für die am wenigsten intensiv bewirtschafteten Anbausysteme (die Feldränder von konventionellen und nach den Vorgaben von Agrarumweltmaßnahmen bewirtschafteten Weizenfeldern) nachgewiesen werden.

Der starke Anstieg der Nutzung landwirtschaftlicher Flächen für den Energiepflanzenanbau wirkt sich auf die Agrarbiodiversität nachteilig aus, da insbesondere der Anteil extensiv bewirtschafteter Felder, in denen der Lichtgenuss am Boden relativ hoch ist, zurückgeht. Eine reduzierte Düngung würde die Beleuchtungsstärke konventionell bewirtschafteter Feldränder erhöhen und damit die Lebensbedingungen für Ackerwildkräuter verbessern. 
Wesche, K., Krause, B., Culmsee, H., Leuschner, C., 2012. Fifty years of change in Central European grassland vegetation: large losses in species richness and animalpollinated plants. Biological Conservation, 150: 76-85.

Wandel in der mitteleuropäischen Grasland-Vegetation in den vergangenen 50 Jahren: große Verluste in der Artenzahl und in tierbestäubten Pflanzenarten

Der Biodiversitätsverlust in der europäischen Agrarlandschaft hat einen besorgniserregend negativen Einfluss auf die funktionelle Diversität. Langzeitstudien, die den Vegetationswandel seit der Industrialisierung der Agrarlandschaft untersuchen, sind jedoch selten. Hier wird der Frage nachgegangen, wie Nutzungsintensivierung und gestiegener Nährstoffeintrag, die in den 1950/60er Jahren begannen, Pflanzengesellschaften des Graslands hinsichtlich ihrer Artenzusammensetzung, Diversität und funktionellen Merkmale verändert haben. Hierfür wurde ein umfangreicher Datensatz aus fünf Auenlandschaften (plus eine Referenzfläche in einem Schutzgebiet) in Norddeutschland ausgewertet. Für die Gebiete waren historische Vegetationsaufnahmen (Plot-Ebene) und Vegetationskarten (Landschafts-Ebene) aus den 1950er, 1960er und 1990er Jahren verfügbar, die im Jahr 2008 wiederholt aufgenommen wurden, sodass für die Analyse Daten über eine Zeitperiode von vier bis fünf Dekaden zur Verfügung standen.

Die Zusammensetzung der Pflanzengesellschaften veränderte sich in allen Untersuchungsgebieten über den Zeitraum von 50 Jahren sehr stark und stand in Beziehung zu steigenden Stickstoffzahlen (Ellenberg-Zeigerwerte, Ellenberg et al., 2001). Auf PlotEbene sank in diesem Zeitraum die Artenzahl um 30-50\%; Verluste in der funktionellen Diversität waren ähnlich hoch. Ein Vergleich der Ergebnisse mit der Referenzfläche in einem Schutzgebiet zeigte, dass die Veränderungen hauptsächlich auf lokale Stickstoffeinträge zurückzuführen sind, weniger jedoch auf einen überregionalen Klimawandel. Es ließ sich ein einheitlicher Trend zu sehr viel artenärmeren Grünlandgesellschaften, in denen mahdtolerante, Stickstoff verlangende, konkurrenzstarke Gräser dominierten, beobachten. Rückläufig waren dagegen Ruderalstrategen, frühblühende Arten und insbesondere insektenbestäubte Kräuter. Der erhebliche Verlust von Nektar produzierenden Kräutern dürfte einen negativen Einfluss auf die Verbreitung von Bestäubern, und dies wiederum Konsequenzen für die Diversität von Tiergemeinschaften in Grasländern haben. Hervorzuheben ist daher die Notwendigkeit von adäquaten Programmen für ein GraslandManagement mit geringen Nährstoffgaben, durch das ökologisch wertvolles Grasland erhalten wird. 


\section{References}

Ackerly, D.D., 2003. Community assembly, niche conservatism, and adaptive evolution in changing environments. International Journal of Plant Sciences, 163: S165-S184.

Aiba, S-I., Kitayama, K., 1999. Structure, composition and species diversity in an altitudesubstrate matrix of rain forest tree communities on Mount Kinabalu, Borneo. Plant Ecology, 140: 139-157.

Aiba, S-I., Kitayama, K., Repin, R., 2002. Species composition and species-area relationships of trees in nine permanent plots in altitudinal sequences on different geological substrates of Mount Kinabalu. Sabah Parks Nature Journal, 5: 7-69.

Araújo, T.M., Higuchi, N., Carvalho, J.A., 1999. Comparison of formulae for biomass content determination in a tropical rain forest site in the state of Pará, Brazil. Forest Ecology and Management, 117: 43-52.

Ariyanti, N.S., Bos, M.M., Kartawinata, K., Tjitrosoedirdjo, S.S., Guhardja, E., Gradstein, S.R., 2008. Bryophytes on tree trunks in natural forests, selectively logged forests and cacao agroforests in Central Sulawesi, Indonesia. Biological Conservation, 141: 25162527.

Ashton, P.S., 2003. Floristic zonation of tree communities on wet tropical mountains revisited. Perspectives in Plant Ecology, Evolution and Systematics, 6: 87-104.

Baker, T.R. et al. (18 authors), 2004. Variation in wood density determines spatial patterns in Amazonian forest biomass. Global Change Biology, 10: 201-220.

Baraloto, C. et al. (11 authors), 2011. Disentangling stand and environmental correlates of aboveground biomass in Amazonian forests. Global Change Biology, 17: 2677-2688.

Bauerkämper, A., 2004. The industrialization of agriculture and its consequences for the natural environment: an inter-German comparative perspective. Historical Social Research, 29: 124-149.

Berg, C.C., Corner, E.J.H., 2005. Moraceae, Ficus. Flora Malesiana, Ser. I, 17/2: 1-730.

Berg, C.C., Culmsee, H., 2011. Ficus schwarzii redefined and two new species of Ficus (Moraceae) from Sulawesi (Indonesia) described. Blumea, 56: 265-269.

BfN, 2008. Naturerbe Buchenwälder. Situationsanalyse und Handlungserfordernisse. Bonn/Insel Vilm.

BfN, 2010. Bioenergie und Naturschutz. Synergien fördern, Risiken vermeiden. Bonn.

BfN, 2014. Die Lage der Natur in Deutschland. Ergebnisse von EU-Vogelschutz- und FFHBericht. Zustand der Lebensräume. Berlin/Bonn. Available at: http://www.bfn.de/fileadmin/MDB/documents/presse/2014/Ergebnisse_FFH-

Bericht_2013_LRT_EHZ_Trend.pdf.

Bignal, E.M., McCracken, D.I., 1996. Low-intensity farming systems in the conservation of the countryside. Journal of Applied Ecology, 33: 413-424.

BMEL, 2014. Der Wald in Deutschland. Ausgewählte Ergebnisse der dritten Bundeswaldinventur. Berlin.

BMELV, 2009. Waldbericht der Bundesregierung 2009. Berlin.

BMELV, 2011. Aufnahmeanweisung für die dritte Bundeswaldinventur (BWI3) (2011-2012). 2nd ed., Bonn.

BMU, 2007. Nationale Strategie zur biologischen Vielfalt. Berlin.

BMU, BMELV, 2010. Nationaler Biomasseaktionsplan für Deutschland. Berlin. 
BNatSchG., 2009. Gesetz über Naturschutz und Landschaftspflege. Bundesgesetzblatt, 1 (51): 2542-2579.

Boege, K., Marquis, R.J., 2005. Facing herbivory as you grow up: the ontogeny of resistance in plants. Trends in Ecology and Evolution, 20: 441-448.

Bohn, U., Neuhäusle, R., Gollub, G., Hettwer, C., Neuhäuslová, Z., Raus, T., Schlüter, H., Weber, H., 2003. Map of the natural vegetation of Europe. Explanatory text with CD-ROM. German Federal Agency for Nature Conservation, Bonn.

Borcard, D., Legendre, P., 2002. All-scale spatial analysis of ecological data by means of principal coordinates of neighbour matrices. Ecological Modelling, 153: 51-68.

Borcard, D., Legendre, P., Drapeau, P., 1992. Partialling out the spatial component of ecological variation. Ecology, 73: 1045-1055.

Brambach, F., Nooteboom, H.P., Culmsee, H., 2013. Magnolia sulawesiana described, and a key to the species of Magnolia (Magnoliaceae) occurring in Sulawesi. Blumea, 58: 271276.

Braun-Blanquet, J., 1964. Pflanzensoziologie: Grundzüge der Vegetationskunde, 3rd ed. Springer, Wien.

Britz, W., Delzeit, R., 2013. The impact of German biogas production on European and global agricultural markets, land use and the environment. Energy Policy, 62: 1268-1275.

Brummitt, R.K., 2001. World geographical scheme for recording plant distributions. Plant Taxonomic Database Standards No. 2, 2nd edn. Carnegie Mellon University, Pittsburgh, PA.

Bruno, J.F., Stochowicz, J.J., Bertness, M.D., 2003. Inclusion of facilitation into ecological theory. Trends in Ecology and Evolution, 18: 119-125.

Budiharta, S., Slik, F., Raes, N., Meijaard, E., Erskine, P.D., Wilson, K.A., 2014. Estimating the aboveground biomass of Bornean forests. Biotropica, 46: 507-511.

Bunting, P., Lucas, R.M., Jones, K., Bean, A.R., 2010. Characterisation and mapping of forest communities by clustering individual tree crowns. Remote Sensing of Environment, 114: 2536-2547.

Cadotte, M., Albert, C.H., Walker, S.C., 2013. The ecology of differences: assessing community assembly with trait and evolutionary distances. Ecology Letters, 16: 12341244.

Cadotte, M.,W., Davies, T.J., Regetz, J., Kembel, S.W., Cleland, E., Oakley, T.H., 2010. Phylogenetic diversity metrics for ecological communities: integrating species richness, abundance and evolutionary history. Ecology Letters, 13: 96-105.

Callaway, R.M., Walker, L.R., 1997. Competition and facilitation: a synthetic approach to interactions in plant communities. Ecology, 78: 1958-1965.

Cannon, C.H., Summers, M., Harting, J.R., Keßler, P.J.A., 2007. Developing conservation priorities based on forest type, condition, and threats in a poorly known ecoregion: Sulawesi, Indonesia. Biotropica, 39: 747-759.

Carstensen, D.W., Lessard, J.P., Holt, B.G., Borregaard, M.K., Rahbek, C., 2013. Introducing the biogeographic species pool. Ecography, 36: 1310-1318.

Cavender-Bares, J., Kozak, K.H., Fine, P.V.A., Kembel, S.W., 2009. The merging of community ecology and phylogenetic biology. Ecology Letters, 12: 693-715.

Cavender-Bares, J., Wilczek, A., 2003. Integrating micro- and macroevolutionary processes in community ecology. Ecology, 84: 592-597.

CBD, 1992. Convention on Biological Diversity. United Nations, New York. 
Chao, A., Shen, T-J., 2003. Nonparametric estimation of Shannon's index of diversity when there are unseen species in the sample. Environmental and Ecological Statistics, 10: 429443.

Chao, A., Shen, T-J., 2010. SPADE (Species Prediction And Diversity Estimation). Program and user's guide available at: http://chao.stat.nthu.edu.tw/; version 2/2009.

Chave, J. (16 authors), 2005. Tree allometry and improved estimation of carbon stocks and balance in tropical forests. Oecologia, 145: 87-99.

Chave, J., 2008. Spatial variation in tree species composition across tropical forests: pattern and process. In: Carson, W.P., Schnitzer, S.A. (eds.), Tropical forest community ecology, pp. 11-30, Wiley-Blackwell, Chichester.

Chave, J., 2013. The problem of pattern and scale in ecology: what have we learned in 20 years? Ecology Letters, 16: 4-16.

Chave, J., Condit, R., Aguilar, S., Hernandez, A., Lao, S., Perez, R., 2004. Error propagation and scaling for tropical forest biomass estimates. Philosophical Transactions of the Royal Society B: Biological Sciences, 359: 409-420.

Chave, J., Coomes, D., Jansen, S., Lewis, S.L., Swenson, N.G., Zanne, A.E., 2009. Towards a worldwide wood economics spectrum. Ecology Letters, 12: 351-366.

Chave, J., Muller-Landau, H.C., Baker, T.R., Easdale, T.A., ter Steege, H., Webb, C.O., 2006. Regional and phylogenetic variation of wood density across 2456 Neotropical tree species. Ecological Applications, 16: 2356-2367.

Chesson, P., 2000. Mechanisms of maintenance of species diversity. Annual Review of Ecology and Systematics, 31: 343-366.

Chytrý M., Tichý L., Hennekens S.M., Schaminée J.H.J., 2014. Assessing vegetation change using vegetation-plot databases: a risky business. Applied Vegetation Science, 17: 32-41.

Chytrý, M., 2001. Phytosociological data give biased estimates of species richness. Journal of Vegetation Science, 12: 439-444.

Chytrý, M., Exner, A., Hrivnák, R., Ujházy, K., Valchovič, M., Willner, W., 2002b. Contextdependence of diagnostic species: a case study of the Central European spruce forests. Folia Geobotanica, 37: 403-417.

Chytrý, M., Otýpková, Z., 2003. Plot sizes used for phytosociological sampling of European vegetation. Journal of Vegetation Science, 14: 563-570.

Chytrý, M., Tichý, L., Holt, J., Botta-Dukát, Z., 2002a. Determination of diagnostic species with statistical fidelity measures. Journal of Vegetation Science, 13: 79-90.

Clark, D.A., 2004. Sources or sinks? The response of tropical forests to current and future climate and atmospheric composition. Philosophical Transactions of the Royal Society B: Biological Sciences, 359: 477-491.

Clark, D.A., Brown, S., Kicklighter, D.W., Chambers, J.Q., Thomlinson, J.R., Ni, J., 2001a. Measuring net primary production in forests: Concepts and field methods. Ecological Applications, 11: 356-370.

Clark, D.A., Brown, S., Kicklighter, D.W., Chambers, J.Q., Thomlinson, J.R., Ni, J., Holland, E.A., 2001b. Net primary production in tropical forests: an evaluation and synthesis of existing field data. Ecological Applications, 11: 371-384.

Colwell, R., 2013. EstimateS v. 9.1.0. Statistical Estimation of Species Richness and Shared Species from Samples. Available at: http://viceroy.eeb.uconn.edu/estimates/ (accessed on 06/01/2014).

Condit, R., 1998. Tropical Forest Census Plots: Methods and results from Barro Colorado Island, Panama and a comparison with other plots. Springer, Berlin Heidelberg. 
Condit, R., Hubbell, S.P., LaFrankie, J.V., Sukumar, R., Manokaran, N., Foster, R.B., Ashton, P.S., 1996. Species-area and species-individual relationships for tropical trees: a comparison of three 50-ha plots. Journal of Ecology, 84: 549-562.

Coomes, D.A., Grubb, P.J., 2003. Colonization, tolerance, competition and seed-size variation within functional groups. Trends in Ecology and Evolution, 18: 283-291.

Corlett, R.T., 2009a. Seed dispersal distances and plant migration potential in tropical East Asia. Biotropica, 41: 592-598.

Corlett, R.T., 2009b. The ecology of tropical East Asia. OUP, Oxford.

Cornelissen, J.H.C. et al. (12 authors), 2003. A handbook of protocols for standardised and easy measurement of plant functional traits worldwide. Australian Journal of Botany, 51: 335-380.

Culmsee, H., 2008. Dysoxylum quadrangulatum, and notes on Meliaceae in Sulawesi. Blumea, 53: 602-606.

Culmsee, H., 2013. Biodiversität in der mitteleuropäischen Kulturlandschaft. In: Siegesmund, S., Snethlage, R. (eds.), Naturstein in der Kulturlandschaft, pp. 30-38, Mitteldeutscher Verlag, Halle.

Culmsee, H., Leuschner, C., 2013. Consistent patterns of elevational change in tree taxonomic and phylogenetic diversity across Malesian mountain forests. Journal of Biogeography, 40: 1997-2010.

Culmsee, H., Leuschner, C., Moser, G., Pitopang, R., 2010. Forest aboveground biomass along an elevational transect in Sulawesi, Indonesia, and the role of Fagaceae in tropical montane rain forests. Journal of Biogeography, 37: 960-974.

Culmsee, H., Pitopang, R., 2009. Tree diversity in sub-montane and lower montane primary rain forests in Central Sulawesi. Blumea, 54: 119-123.

Culmsee, H., Pitopang, R., Mangopo, H., Sabir, S., 2011. Tree diversity and phytogeographical patterns of tropical high mountain rain forests in Central Sulawesi, Indonesia. Biodiversity and Conservation, 20: 1103-1123.

Culmsee, H., Schmidt, M., Schmiedel, I., Schacherer, A., Meyer, P., Leuschner, C., 2014. Predicting the distribution of forest habitat types using indicator species to facilitate systematic conservation planning. Ecological Indicators, 37: 131-144.

Davies, T.J., Barraclough, T.G., Chase, M.W., Soltis, P.S., Soltis, D.E., Savolainen, V., 2004. Darwin's abominable mystery: insights from a supertree of the angiosperms. Proceedings of the National Academy of Sciences of the United States of America, 101: 1904-1909.

de Gouvenain, R.C., Silander, J.A., 2003. Do tropical storm regimes influence the structure of tropical lowland rain forests? Biotropica, 35: 166-180.

de Sherbinin, A., Carr, D., Cassels, S., Jiang, L., 2007. Population and environment. Annual Review of Environment and Resources, 32: 345-373.

Dengler, J. et al. (14 authors), 2011. The Global Index of Vegetation-Plot Databases (GIVD): a new resource for vegetation science. Journal of Vegetation Science, 22: 582-597.

Dengler, J., Oldeland, J., 2010. Effects of sampling protocol on the shapes of species richness curves. Journal of Biogeography, 37: 1698-1705.

Destatis, 2013. Feldfrüchte und Grünland - Ackerland nach Hauptfruchtgruppen und Fruchtarten. https://www.destatis.de/DE/ZahlenFakten/Wirtschaftsbereiche/LandForstwirtschaftFischerei/FeldfruechteGruenland/Tabellen/AckerlandHauptfruchtgruppenFruchtarten.html (accessed 17.12.13). 
Dickinson, C., Siqueira, P., Clewley, D., Lucas, R., 2013. Classification of forest composition using polarimetric decomposition in multiple landscapes. Remote Sensing of Environment, 131: 206-214.

Dierschke, H., Briemle, G., 2002. Kulturgrasland. Ulmer, Stuttgart.

Dixon, R.K., Brown, S., Houghton, R.A., Solomon, A.M., Trexler, M.C., Wisniewski, J., 1994. Carbon pools and flux of global forest ecosystems. Science, 263: 185-190.

Don, A. et al. (18 authors), 2012. Land-use change to bioenergy production in Europe: implications for greenhouse gas balance and soil carbon. Global Change Biology Bioenergy, 4: 372-391.

EEA, 2010. The European Environment-State and Outlook 2010: Synthesis. European Environment Agency, Copenhagen.

Ellenberg, H., Weber, H. E., Düll, R., Wirth, V., Werner, W., 2001. Zeigerwerte von Pflanzen in Mitteleuropa, 3rd ed. Scripta Geobotanica, 18: 1-262.

EU, 2013. Overview of CAP Reform 2014-2020. Agricultural Policy Perspectives Brief, 5, December 2013. Available at: http://ec.europa.eu/agriculture/policy-perspectives/policybriefs/05_en.pdf (accessed 07.10.2014).

European Commission, 2006. Assessment, Monitoring and Reporting Under Article 17 of the 706 Habitats Directive: Explanatory Notes and Guidelines. Final Draft, October 2006. Brussels.

European Commission, 2011. Our life insurance, our natural capital: an EU biodiversity strategy to 2020. Brussels.

Evans, D., 2010. Interpreting the habitats of Annex I: past, present and future. Acta Botanica Gallica, 157: 677-686.

Faith, D.P., 1992. Conservation evaluation and phylogenetic diversity. Biological Conservation, 61: 1-10.

Feldpausch, R.R. et al. (53 authors), 2011. Height-diameter allometry of tropical forest trees. Biogeosciences, 9: 1081-1106.

Figlar, R.B., Nooteboom, H.P., 2004. Notes on Magnoliaceae IV. Blumea, 49: 87-100.

Flohre, A., et al. (23 authors), 2011. Agricultural intensification and biodiversity partitioning in European landscapes comparing plants, carabids, and birds. Ecological Applications, 21: 1772-1781.

FNR, 2013a. Cultivation of renewable resources in Germany. Fachagentur Nachwachsende Rohstoffe, Gülzow-Prüzen.

FNR, 2013b. Maisanbau in Deutschland. Fachagentur Nachwachsende Rohstoffe, GülzowPrüzen.

Frahm, J.P., 1990. The ecology of epiphytic bryophytes of Mt. Kinabalu, Sabah (Malaysia). Nova Hedwigia, 51: 121-132.

Frahm, J.P., Gradstein, S.R., 1991. An altitudinal zonation of tropical rain-forests using bryophytes. Journal of Biogeography, 18: 669-678.

Gaston, K.J., Jackson, S.F., Nagy, A., Canté-Salazar, L., Johnson, M., 2008. Protected areas in Europe. Principle and practice. Annals of the New York Academy of Sciences, 1134: 97-119.

Gentry, A.H., 1988. Changes in plant community diversity and floristic composition on environmental and geographical gradients. Annals of the Missouri Botanic Gardens, 75: 1-34.

Glaser, F.F., Hauke, U., 2004. Historisch alte Waldstandorte und Hudewälder in Deutschland. AngewandteLandschaftsökologie, 61: 1-193. 
Glaves, P., Rotherham, I.D., Wright, B., Handley, C., Birbeck, J., 2009. A survey of the coverage, use and application of ancient woodland indicator lists in the UK. Hallam Environmental Consultants Ltd., Biodiversity and Landscape History Research Institute/Geography, Tourism and Environment Change Research Unit, Sheffield Hallam University, Sheffield.

Gotelli, N., Colwell, R.K., 2001. Quantifying biodiversity: Procedures and pitfalls in the measurement and comparison of species richness. Ecology Letters, 4: 379-391.

Grace, J., Meir, P., 2009. Tropical rain forests as old-growth forests. Ecological studies, 207: 391-408.

Gradstein, S., Culmsee, H., 2010. Bryophyte diversity on tree trunks in montane forests of Central Sulawesi, Indonesia. Tropical Bryology, 31: 95-105.

Grime, J.P., 2001. Plant strategies, vegetation processes, and ecosystem properties. Wiley, Chichester.

Gustavsson, E., Lennartsson, T., Emanuelsson, M., 2007. Land use more than 200 years ago explains current grassland plant diversity in a Swedish agricultural landscape. Biological Conservation, 138: 47-59.

Hall, R., 2009. Southeast Asia's changing palaeogeography. Blumea, 54: 148-161.

Hellawell, J.M., 1991. Development of a rationale for monitoring. In: Goldsmith, B. (ed.): Monitoring for conservation and ecology, pp. 1-14. Chapman \& Hall. London.

Henle, K., et al. (13 authors), 2008. Identifying and managing the conflicts between agricultureand biodiversity conservation in Europe-a review. Agriculture Ecosystems and Environment, 124: 60-71.

Hermy, M., Honnay, O., Firbank, L., Grashof-Bokdam, C., Lawesson, J.E., 1999. An ecological comparison between ancient and other forest plant species of Europe, and the implications for forest conservation. Biological Conservation, 91: 9-22.

Hertel, D., Moser, G., Culmsee, H., Erasmi, S., Horna, V., Schuldt, B., Leuschner, C., 2009. Below- and above-ground biomass and net primary production in a paleotropical natural forest (Sulawesi, Indonesia) as compared to neotropical forests. Forest Ecology and Management, 258: 1904-1912.

Heywood, V.H., Brummit, R.K., Culham, A., Seberg, O., 2007. Flowering plant families of the world. Firefly Books, Ontario.

Higgins, M.A., Ruokolainen, K. 2004. Rapid tropical forest inventory: a comparison of techniques based on inventory data from Western Amazonia. Conservation Biology, 18: 799-811.

Hill, M.O., Šmilaur, P., 2005. TWINSPAN for Windows Version 2.3. Centre for Ecology and Hydrology/University of South Bohemia, Huntingdon/České Budĕjovice.

Hötker, H., Leuschner, C., 2014. Naturschutz in der Agrarlandschaft am Scheideweg. Misserfolge, Erfolge, neue Wege. Michael Otto Stiftung für Umweltschutz, Hamburg.

Hubbel, S.P., 2001. The Unified Neutral Theory of Biodiversity and Biogeography. Monographs in Population Biology, 32: 1-375.

Ihse, M., 1995. Swedish agricultural landscapes-patterns and changes during the last 50 years, studied by aerial photos. Landscape and Urban Planning, 31: 21-37.

Jedicke, E., 2012. 20 Jahre Natura 2000 - Zeit für eine Qualitätsoffensive. Naturschutz und Landschaftsplanung, 44: 129-130.

Johnson, M.T.M., Stinchcombe, J.R., 2007. An emerging synthesis between community ecology and evolutionary biology. Trends in Ecology and Evolution, 22: 250-257.

Jost, L., 2006. Entropy and diversity. Oikos, 113: 363-375. 
Jost, L., 2007. Partitioning diversity into independent alpha and beta components. Ecology, 88: 2427-2439.

Kaiser, T., Schlumprecht, H., Finck, P., Riecken, U., 2013. Biotopkartierungen in den deutschen Bundesländern - aktueller Stand und Methodenvergleich. Natur und Landschaft, 88: 97-102.

Kent, M., Coker, P., 1992. Vegetation description and analysis. A practical approach. Wiley, Chichester.

Keßler, P.J.A., Bos, M., Sierra Saza, S.E.C., Kop, S., Willemse, L.P.M, Pitopang, R., Gradstein, S.R., 2002. Checklist of woody plants of Sulawesi, Indonesia. Blumea Supplement, 14: 1-160.

Kimberley, A., Blackburn, G.A., Whyatt, J.D., Kirby, K., Smart, S.M., 2013. Identifying the trait syndromes of conservation indicator species: how distinct are British ancient woodland indicator plants from other woodland species? Applied Vegetation Science, 16: 667-675.

Kissinger, G., Herold, M., de Sy, V., 2012. Drivers of deforestation and forest degradation: A synthesis report for REDD+ policymakers. Lexeme Consulting, Vancouver.

Kitayama, K., Aiba, S., 2002. Ecosystem structure and productivity of tropical rain forests along altitudinal gradients with contrasting soil phosphorus pools on Mount Kinabalu, Borneo. Journal of Ecology, 90: 37-51.

Klotz, S., Kühn, I., Durka, W., 2002. BIOLFLOR - Eine Datenbank zu biologischökologischen Merkmalen der Gefäßpflanzen in Deutschland. Schriftenreihe für Vegetationskunde, 38: 1-333.

Koch, S., 2009. Driving forces of tropical deforestation at the forest frontiers of Central Sulawesi. An institutional and demographic perspective. Pacific News, 32: 18-21.

Körner, C., 2000. Why are there global gradients in species richness? Mountains might hold the answer. Trends in Ecology and Evolution, 15: 513-514.

Körner, C., 2007. The use of 'altitude' in ecological research. Trends in Ecology and Evolution, 22: 569-574.

Körner, C., Pausen, J., Spehn, E.M., 2011. A definition of mountains and their bioclimatic belts for global comparisons of biodiversity data. Alpine Botany, 121: 73-78.

Krause, B., Culmsee, H., 2013. The significance of habitat continuity and current management on the compositional and functional diversity of grasslands in the uplands of Lower Saxony, Germany. Flora, 208: 299-311.

Krause, B., Culmsee, H., Wesche, K., Bergmeier, E., Leuschner, C., 2011. Habitat loss of floodplain meadows in north Germany since the 1950s. Biodiversity and Conservation, 20: 2347-2364.

Krauss, J., et al. (17 authors), 2010. Habitat fragmentation causes immediate and timedelayed biodiversity loss at different trophic levels. Ecology Letters, 13: 597-605.

Legendre, P., Legendre, L., 1998. Numerical ecology. 2nd ed. Developments in Environmental Modelling, 20: 1-853.

Lepš, J., Šmilauer, P., 2003. Multivariate analysis of ecological data using CANOCO. Cambridge University Press, Cambridge.

Letts, M.G., Mulligan, M., Rinçon-Romero, M.E., Bruijnzeel, L.A., 2010. Environmental controls on photosynthetic rates of lower montane cloud forest vegetation in southwestern Colombia. In: Bruijnzeel, L.A., Scatena, F.N., Hamilton, L.S. (eds.), Tropical montane cloud forests, pp. 465-478. Cambridge University Press, New York.

Leuschner, C., Moser, G., Hertel, D., Erasmi, S., Leitner, D., Culmsee, H., Schuldt, B., Schwendenmann, L., 2013. Conversion of tropical moist forest into cacao agroforest: 
Consequences for carbon pools and annual C sequestration. Agroforestry Systems, 87: 1173-1187.

Levin, S.A., 1992. The problem of pattern and scale in ecology. Ecology, 73: 1943-1967.

Lewis, S.L. et al. (63 authors), 2013. Above-ground biomass and structure of 260 African tropical forests. Philosophical Transactions of the Royal Society B: Biological Sciences, 368: 1-14.

Lieberman, D., Lieberman, M., Peralta, R., Harthorn, G.S., 1996. Tropical forest structure and composition on a largescale altitudinal gradient in Costa Rica. Journal of Ecology, 84: 137-152.

Lucas, R., Medcalf, K., Brown, A., Bunting, P., Breyer, J., Clewley, D., Keyworth, S., Blackmore, P., 2011. Updating the Phase 1 habitat map of Wales, UK, using satellite sensor data. ISPRS J. Photogrammetry and Remote Sensing, 66: 81-102.

Mabberley, D.J., Pannell, C.M., Sing, A.M., 1995. Meliaceae. Flora Malesiana, Ser. I, 12: 1407.

MacArthur, R.H., 1984. Geographical Ecology: Patterns in the Distribution of Species. Reprint 1st edn. of 1972. Princeton University Press, New York.

Magurran, A.E., 2004. Measuring biological diversity. Blackwell, Oxford.

Malhi, Y. et al. (26 authors), 2006. The regional variation of aboveground live biomass in oldgrowth Amazonian forests. Global Change Biology, 12: 1107-1138.

Malhi, Y., Phillips, O.L., 2004. Tropical forests and global atmospheric change: a synthesis. Philosophical Transactions of the Royal Society B: Biological Sciences, 359: 549-555.

Manos, P.S., Cannon, C.H., Oh, S.-H., 2008. Phylogenetic relationships and taxonomic status of the paleoendemic Fagaceae of western North America: recognition of a new Genus, Notholithocarpus. Madroño, 55: 181-190.

Manos, P.S., Stanford, A.M., 2001. The historical biogeography of Fagaceae: tracking the Tertiary history of temperate and subtropical forests on the Northern Hemisphere. International Journal of Plant Sciences, 162: S77-S93.

Margules, C.R., Pressey, R.L., 2000. Systematic conservation planning. Nature, 405: 243253.

McGarigal, K., Cushman, S.A., Neel, M.C., Ene, E., 2002. FRAGSTATS: Spatial pattern analysis program for categorical maps. Computer software program produced by the authors at the University of Massachusetts, Amherst. Software download at: http://www.umass.edu/landeco/research/fragstats/fragstats.html.

McGill, B.J., Enquist, B.J., Weiher, E., Westoby, M., 2006. Rebuilding community ecology from functional traits. Trends in Ecology and Evolution, 21: 178-185.

McGrath, D.A., Duryea, M.L., Comerford, N.B., Cropper, W.P., 2000. Nitrogen and phosphorus cycling in an Amazonian agroforest eight years following forest conversion. Ecological Applications, 10: 1633-1647.

Medina, E., 2007. Tropical forests: diversity and function of dominant life-forms. In: Pugnaire, F.I., Valladares, F., Functional Plant Ecology, 2nd ed., pp. 313-350, CRC Press, New York.

Meyer, P. et al. (15 authors), 2001. Untersuchung der Waldstruktur und ihrer Dynamik in Naturwaldreservaten. IHW-Verlag, Eching.

Meyer, P., Bücking, W., Gehlhar, U., Schulte, U., Steffens, R., 2007. Das Netz der Naturwaldreservate in Deutschland: Flächenumfang, Repräsentativität und Schutzstatus im Jahr 2007. Forstarchiv, 78: 188-196. 
Meyer, S., Wesche, K., Krause, B., Leuschner, C., 2013. Dramatic losses of specialist arable plants in Central Germany since the 1950/60s - a cross-regional analysis. Diversity and Distributions, 19: 1175-1187.

Milchunas, D.G., Noy-Meir, I., 2002. Grazing refuges, external avoidance of herbivory and plant diversity. Oikos, 99: 113-130.

Mori, S.A., Boom, B.M, De Carvalho, A., Dos Santos, T.S., 1983. Southern Bahian moist forests. The Botanical Review, 49: 155-232.

Moser, G., Röderstein, M., Soethe, N., Hertel, D., Leuschner, C., 2008. Altitudinal changes in stand structure and biomass allocation of tropical mountain forests in relation to microclimate and soil chemistry. Ecological Studies, 198: 229-242.

Myers, N., Mittermeier, R.A., Mittermeier, C.G., da Fonseca, G.A.B., Kent, J., 2000. Biodiversity hotspots for conservation priorities. Nature, 403: 853-858.

Nagendra, H., Lucas, R., Honrado, J.P., Jongman, R.H.G., Trantino, C., Adamo, M., Mairota, P., 2013. Remote sensing for conservation monitoring: Assessing protected areas, habitat extent, habitat condition, species diversity, and threats. Ecological Indicators, 33: 45-59.

Nathan, R., Schurr, F.M., Spiegel, O., Steinitz, O., Trakhtenbrot, A., Tsoar, A., 2008. Mechanisms of long-distance seed dispersal. Trends in Ecology and Evolution, 23: 638647.

Nitsch, H., Osterburg, B., Roggendorf, W., Laggner, B., 2012. Cross compliance and the protection of grassland - illustrative analyses of land use transitions between permanent grassland and arable land in German regions. Land Use Policy, 29: 440-448.

Nooteboom, H.P., 1988. Magnoliaceae. Flora Malesiana, Ser. I, 10/3: 561-605.

Oksanen, J., 2013. Multivariate analysis of ecological communities in R: vegan tutorial. Available online: http://cc.oulu.fi/ jarioksa/opetus/metodi/vegantutor.pdf.

Palmer, M.W., 1993. Potential biases in site and species selection for ecological monitoring. Environmental Monitoring and Assessment. 26: 277-282.

Paoli, G.D., Curran, L.M., Slik, J.W.F., 2008. Soil nutrients affect spatial patterns of aboveground biomass and emergent tree density in southwestern Borneo. Oecologia, 155: 287-299.

Perrin, P.M., Daly, O.H., 2010. A provisional inventory of ancient and long established woodland in Ireland. Irish Wildlife Manuals, 46: 1-65.

Plieninger, T., Höchtl, F., Spek, T., 2006. Traditional land-use and nature conservation in Europen rural landscapes. Environmental Science and Policy, 9: 317-321.

Prach, K., 2008. Vegetation changes in a wet meadow complex during the past half-century. Folia Geobotanica, 43: 119-130.

Primack, R., Corlett, R., 2005. Tropical rain forests. An ecological and biogeographical comparison. Blackwell, Malden MA, Oxford.

Quesada, C.A. et al. (47 authors), 2012. Basin-wide variations in Amazon forest structure and function are mediated by both soils and climate. Biogeosciences, 9: 2203-2246.

Raich, J.W., Russell, A.E., Vitousek, P.M., 1997. Primary productivity and ecosystem development along an elevational gradient on Mauna Loa, Hawai'i. Ecology, 78: 707-721.

Rao, C.R., 1982. Diversity and dissimilarity coefficients - a unified approach. Theoretical Population Biology, 21: 24-43.

Rennwald, E. (ed.), 2000. Verzeichnis und Rote Liste der Pflanzengesellschaften Deutschlands. Schriftenreihe für Vegetationskunde, 35: 1-800.

Ricklefs, R.E., 2008. Disintegration of the ecological community. The American Naturalist, 172: $741-750$. 
Rose, F., 1999. Indicators of ancient woodland - the use of vascular plants in evaluating ancient woods for nature conservation. British Wildlife, 10: 241-251.

Saatchi, S.S., Houghton, R.A., Dos Santos Alvalá, R.C., Soares, J.V., Yu, Y., 2007. Distribution of aboveground live biomass in the Amazon basin. Global Change Biology, 13: 816-837.

Sargent, R.D., Ackerly, D.D., 2008. Plant-pollinator interactions and the assembly of plant communities. Trends in Ecology and Evolution, 23: 123-130.

Schaminée, J.H.J., Hennekens, S.M., Ozinga, W.A., 2007. Use of the ecological information system SynBioSys for the analysis of large datasets. Journal of Vegetation Science, 18: 463-470.

Schmidt, M., Kriebitzsch, W.-U., Ewald, J. (eds.), 2011. Waldartenlisten der Farn- und Blütenpflanzen, Moose und Flechten Deutschlands. BfN-Skripten, 299: 1-111.

Schmidt, M., Mölder, A., Schönfelder, E., Engel, F., Schmiedel, I., Culmsee, H., 2014. Determining ancient woodland indicator plants for practical use: A new approach developed in northwest Germany. Forest Ecology and Management, 330: 228-239.

Schroth, G., D'Angelo, S.A., Teixeira, W.G., Haag, D., Lieberei, R., 2002. Conversion of secondary forest into agroforestry and monoculture plantations in Amazonia: consequences of biomass, litter and soil carbon stocks after 7 years. Forest Ecology and Management, 163: 131-150.

Seifert, C., Leuschner, C., Meyer, S., Culmsee, H., 2014. Inter-relationships between crop type, management intensity and light transmissivity in annual crop systems and their effect on farmland plant diversity. Agriculture, Ecosystems and Environment, 195: 173182.

Shearman, P.L., Ash, J., Mackey, B., Bryan, J.E., Lokes, B., 2009. Forest conversion and degradation in Papua New Guinea 1972-2002. Biotropica, 41: 379-390.

Silvertown, J., 2004. Plant coexistence and the niche. Trends in Ecology and Evolution, 19: 605-611.

Silvertown, J., Dodd, M., Gowing, D., Lawson, C., McConway, K., 2006. Phylogeny and the hierarchical organization of plant diversity. Ecology, 87: S39-S49.

Slik, J.W.F. et al. (16 authors), 2010. Environmental correlates of tree biomass, basal area, wood specific gravity and stem density gradients in Borneo's tropical forests. Global Ecology and Biogeography, 19: 50-60.

Slik, J.W.F. et al. (31 authors), 2011. Soils on exposed Sunda Shelf shaped biogeographic patterns in the equatorial forests of Southeast Asia. Proceedings of the National Academy of Sciences of the United States of America, 108: 12343-12347.

Slik, J.W.F., 2006. Estimating species-specific wood density from the genus average in Indonesian trees. Journal of Tropical Ecology, 22: 481-482.

Sodhi, N.S., Koh, L.P., Brook, B.W., Ng, P.K.L., 2004. Southeast Asian biodiversity: an impending disaster. Trends in Ecology and Evolution, 19: 655-660.

Spakman, W., Hall, R., 2010. Surface deformation and slab-mantle interaction during Banda arc subduction rollback. Nature Geoscience, 3: 562-566.

Spracklen, D.V., Righelato, R., 2014. Tropical montane forests are a larger than expected global carbon store. Biogeosciences, 11: 2741-2754.

Srivastava, D.S., Cadotte, M.W., MacDonald, A.M., Marushia, R.G., Mirotchnick, N., 2012. Phylogenetic diversity and the functioning of ecosystems. Ecology Letters, 15: 637-648. 
Stelbrink, B., Albrecht, C., Hall, R., von Rintelen, T., 2012. The biogeography of Sulawesi revisited: is there evidence for a vicariant origin of taxa on Wallace's "anomalous island"? Evolution, 66: 2252-2271.

Stevens, P.F., 2001 onwards. Angiosperm phylogeny website. Missouri Botanical Garden, St Louis, MO. Available at: http://www.mobot.org/MOBOT/research/APweb/.

Stoate, C., Boatman, N.D., Borralho, R.J., Rio Carvalho, C., de Snoo, G.R., Eden, P., 2001. Ecological impacts of arable intensification in Europe. Journal of Environmental Management, 63: 337-365.

Swenson, N.G., Enquist, B.J., 2007. Ecological and evolutionary determinants of a key plant functional trait: wood density and its community-wide variation across latitude and elevation. American Journal of Botany, 94: 451-459.

Tichý, L., Chytrý, M., 2006. Statistical determination of diagnostic species for site groups of unequal size. Journal of Vegetation Science, 17: 809-818.

Tilman, D., 1994. Competition and biodiversity in spatially structured habitats. Ecology, 75: 2-16.

Tsiripidis, I., Bergmeier, E., Fotiadis, G., Dimopoulos, P., 2009. A new algorithm for the determination of differential taxa. Journal of Vegetation Science, 20: 233-240.

Tuomisto, H., 2010a. A diversity of beta diversities: straightening up a concept gone awry. Part 1. Defining beta diversity as a function of alpha and gamma diversity. Ecography, 33: 2-22.

Tuomisto, H., 2010b. A diversity of beta diversities: straightening up a concept gone awry. Part 2. Quantifying beta diversity and related phenomena. Ecography, 33: 23-45.

Vamosi, S.M., Heard, S.B., Vamosi; J.C., Webb, C.O., 2008. Emerging patterns in the comparative analysis of phylogenetic community structure. Molecular Ecology, 18: 572592.

van Balgooy, M.M.J., Tantra, I.G.M., 1986. The vegetation in two areas in Sulawesi, Indonesia. Buletin Penelitian Hutan, Bogor.

van der Maarel, E., 2005. Vegetation ecology - an overview. In: van der Maarel, E. (ed.), Vegetation ecology, pp. 1-51, Blackwell, Oxford.

van Steenis, C.G.G.J. (ed.), 1948-2010. Flora Malesiana, Ser. I, Spermatophyta. Jakarta/Leiden.

van Steenis, C.G.G.J., 1972. The mountain flora of Java. E.J. Brill, Leiden.

van Steenis, C.G.G.J., 1984. Floristic altitudinal zones in Malesia. Botanical Journal of the Linnean Society, 89: 289-292.

Verheyen, K., Honnay, O., Motzkin, G., Hermy, M., Foster, D.R., 2003. Response of forest plant species to land-use change: a life-history trait-based approach. Journal of Ecology, 91: 563-577.

von Drachenfels, O., 2004. Kartierschlüssel für Biotoptypen in Niedersachsen. Naturschutz Landschaftspflege in Niedersachsen, vol A/4. Niedersächsisches Landesamt für Ökologie, Hildesheim.

Vos, W., Meekes, H., 1999. Trends in European cultural landscape development: perspectives for a sustainable future. Landscape and Urban Planning, 46: 3-14.

Wallace, A.R., 1869. The Malay Archipelago. Harper and Brothers, New York.

Wang, H.Q., Hall, C.A.S., Scatena, F.N., Fetcher, N., Wu, W., 2003. Modelling the spatial and temporal variability in climate and primary productivity across the Luquillo Mountains, Puerto Rico. Forest Ecology and Management, 179: 69-94. 
Weaver, P.L., Murphy, P.G., 1990. Forest structure and productivity in Puerto Rico, Luquillo Mountains. Biotropica, 22: 69-82.

Webb, C.O, Ackerly, D.D., Kembel, S.W., 2009. Phylocom: software for the analysis of phylogenetic community structure and trait evolution. Bioinformatics, 24: 2098-2100.

Webb, C.O., Ackerly, D.D., McPeek, M.A., Donoghue, M.J., 2002. Phylogenies and community ecology. Annual Review of Ecology and Systematics, 33: 475-505.

Webb, C.O., Cannon, C.H., Stuart, J.D., 2008. Ecological organization, biogeography, and the phylogenetic structure of tropical forest tree communities. In: Carson, W.P., Schnitzer, S.A. (eds.), Tropical forest community ecology, pp. 79-97, Wiley-Blackwell, Chichester.

Weiers, S., Bock, M., Wissen, M., Rossner, G., 2004. Mapping and indicator approaches for the assessment of habitats at different scales using remote sensing and GIS methods. Landscape and Urban Planning, 67: 43-65.

Weiger, H., 1990. Landwirtschaft und Naturschutz Situation, Defizite, Strategien. Forstwissenschaftliches Centralblatt, 109: 358-377.

Wesche, K., Krause, B., Culmsee, H., Leuschner, C., 2012. Fifty years of change in Central European grassland vegetation: large losses in species richness and animal-pollinated plants. Biological Conservation, 150: 76-85.

Westoby, M., Wright, I.J., 2006. Land-plant ecology on the basis of functional traits. Trends in Ecology and Evolution, 21: 261-268.

Whittaker, R.H., 1960. Vegetation of the Siskiyou Mountains, Oregon and California. Ecological Monographs, 30: 279-338.

Whittaker, R.H., 1972. Evolution and measurement of species diversity. Taxon, 21: 213-251.

Whittaker, R.J., Araújo, M.B., Jepson, P., Ladle, R.L., Watson, J.E.M., Willis, K.J., 2005. Conservation Biogeography: assessment and prospect. Diversity and Distributions, 11: 323.

Whittaker, R.J., Willis, K.J., Field, R., 2001. Scale and species richness: towards a general, hierarchical theory of species diversity. Journal of Biogeography, 28: 453-470.

Wiens, J.A., 1989. Spatial scaling in ecology. Functional Ecology, 3: 385-397.

Wiens, J.J., Donoghue, M.J., 2004. Historical biogeography, ecology and species richness. Trends in Ecology and Evolution, 19: 639-644.

Wikström, N., Savolainen, V., Chase, M.W., 2001. Evolution of the angiosperms: calibrating the family tree. Proceedings of the Royal Society B: Biological Sciences, 268: 2211-2220.

Wozniak, M., Leuven, R.S.E.W., Lenders, H.J.R., Chmielewski, T.J., Geerling, G.W., Smits, A.J.M., 2009. Assessing landscape change and biodiversity values of the Middle Vistula river valley, Poland, using BIO-SAFE. Landscape and Urban Planning, 92: 210-219.

Wright, S.J., 2002. Plant diversity in tropical forests: a review of mechanisms of species coexistence. Oecologia, 130: 1-14.

Wulf, M., 2004. Auswirkungen des Landschaftswandels auf die Verbreitungsmuster von Waldpflanzen. Schweizerbart'sche Verlagsbuchhandlung, Stuttgart. 